\title{
Normal Faulting and Volcanism in the Kora 3D Seismic Volume
}

\author{
lan Hurst
}

\section{6}

A thesis submitted to Victoria University of Wellington in partial fulfilment of requirements for the degree of Master of Science in Petroleum Geoscience

School of Geography, Environment and Earth Sciences

Victoria University of Wellington 


\section{Abstract}

The spatial and temporal relationship between normal faulting and volcanism in offshore Western North Island, New Zealand can be used to gain insight into basin formation, hydrocarbon resources, regional tectonics, and large subduction processes. It is hypothesised that there is a causal relationship between volcanic activity and faulting, however, within the Taranaki Kora 3D seismic volume (survey) this relationship has not yet been explored. The overall aim of this thesis was to map and identify whether there is a relationship between volcanism and normal faulting within the Kora 3D survey.

A causal relationship in location and timing between volcanic processes and fault activity was discovered in this study. Two novel models were created to explain the creation of the local stress leading to this causal relationship. The first model uses intrusive magma build up and the second extrusive cone building to explain the changes in local stress. These models not only support the causal relationship between volcanism and faulting activity but also provide a new understanding into how Kora volcanic cone activity may have influenced active faulting in the Kora 3D survey.

Application of this new information will allow innovative insights into basin formation, regional and local tectonics, and subducting plate geometry in the Taranaki Basin. This research could be utilized to increase knowledge for prospecting and reduce geologic uncertainty, which is of importance for the New Zealand petroleum industry at this northern end of the Taranaki Basin. 


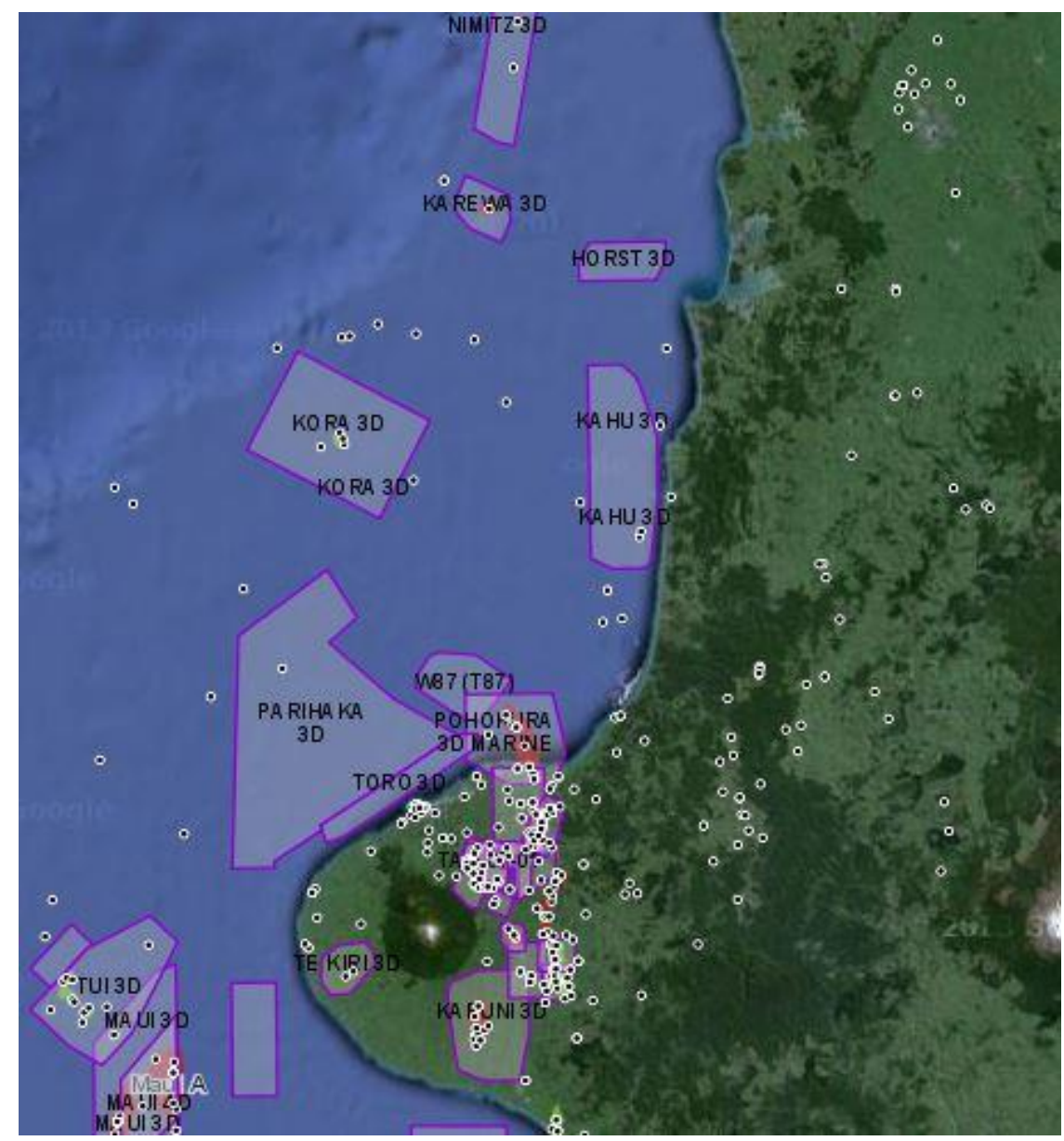

Figure 1.1. Location of 3D seismic surveys in the Northern Taranaki region including Kora 3D. Black circles are well locations while purple polygons show the location of 3D seismic volumes. $2 D$ seismic data is not shown. Data taken from GNS Petroleum Basin Explorer (http://www.gns.cri.nz/Home/Our-Science/EnergyResources/Oil-and-Gas/Petroleum-Basin-Explorer). 


\section{Acknowledgements}

Throughout my five years of study, my friends, family, and supervisors are the people that I have relied on both emotionally and physically and deserve the upmost thanks and appreciation. The group is too large to all thank now, and I am bound to miss someone, however, they know who they are and all the gratitude and respect I have for them.

First thanks must go to my parents who have stood by me and given me guidance (sometimes maybe a tad to forceful) ever since I can remember. You have supplied both a means to study and the scientific tools I needed to get through 5 years of university. I am forever thankful. I also have to thank my younger brother Jack. Always a source of meaningless banter and activities. Your fresh look on life gave me clarity and a clear head when it was needed most.

Andy Nicol and Tim Stern my patient and knowledgeable supervisors also need to be thanked. This thesis has been a long road and they were both there when needed. Andy you provided the idea of this thesis and your scientific experience in this area in un-valuable. Whenever you were needed to send me down the right path and keep my eye on the end goal, you were there. Thank you for your help. Tim your door was always open, and to me you were the shrine of knowledge. You again kept my eye on the end goal, and stopped me getting bogged down in the unnecessary. Hannu Seebeck, thank you for setting this project up for, and being a stable voice of reason at GNS Science. Thank you to Rob Funnel at GNS Science for allowing me to use the company's resources and believing in me. To all the other staff in the Earth Sciences department and Victoria University, and the Petroleum Division at GNS Science, I owe a great gratitude for allowing me to experience and learn the science of Geology and Geophysics.

To my friends, you have always been there with the light hearted banter I needed to relieve the stresses of studying. Special thanks has to go to Hamish Cameron, who in his own was my third supervisor. You are going to go far in life, and I cannot ask for 
a better friend. To the PGEO lads, Tom Ayling, Harry Greenfield, and Johnny Wang, we all did it lads. In addition, final thanks to my good friends in Palmerston North, good times with good people.

"The Maori word, Kora, is a synonym for spark and refers to the primordial void (pore space) or first cause of the universe in which all matter, elements, and forces were implicit and potentially emergent."

-Bergman, et al., 1992 


\section{Contents}

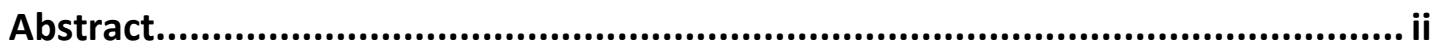

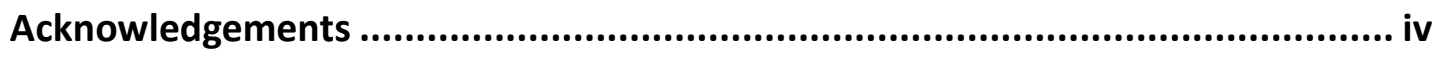

Table of Contents .............................................................................. vi

Table of Figures .................................................................................... ix

Table of Appendix Figures.............................................................................. $\mathrm{x}$

Chapter 1 Thesis introduction ................................................................ 1

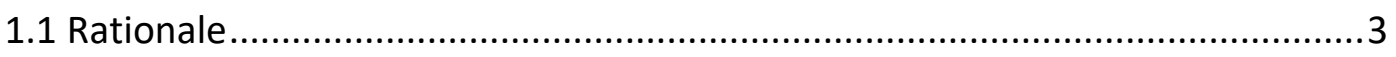

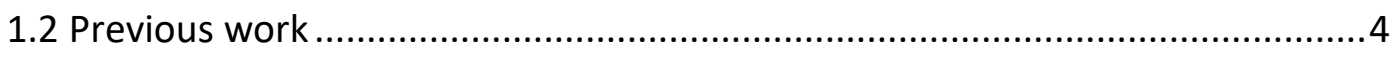

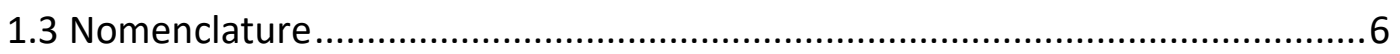

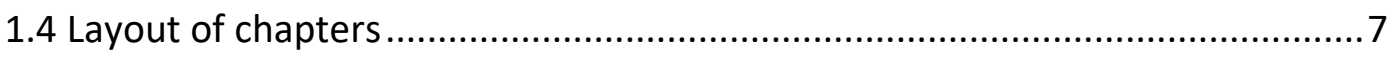

Chapter 2 Geological background......................................................... 8

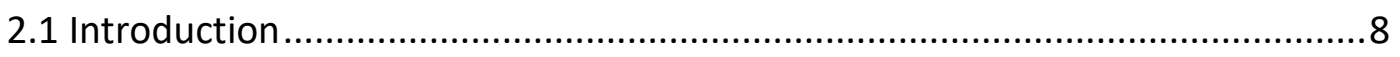

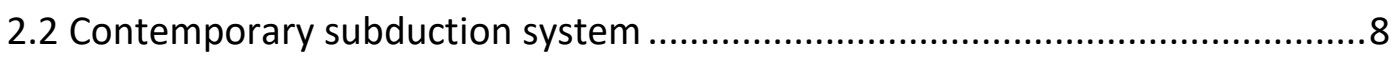

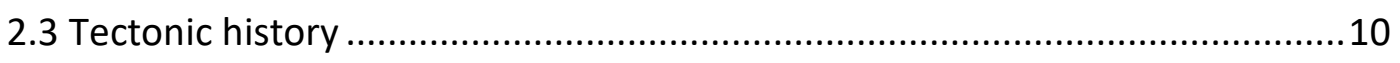

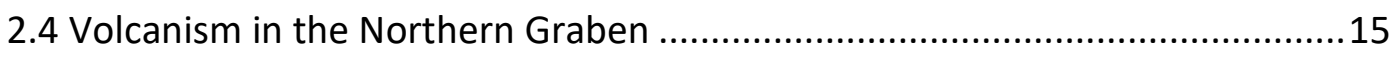

2.6 Southward migration of faulting and volcanism ..........................................15

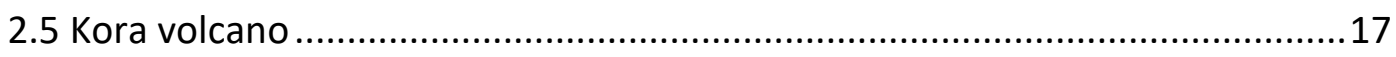

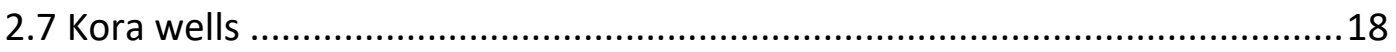

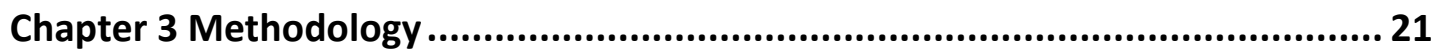

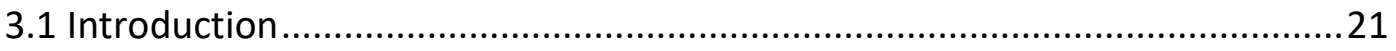

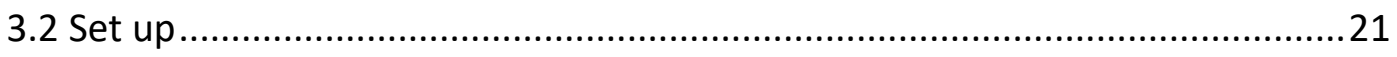

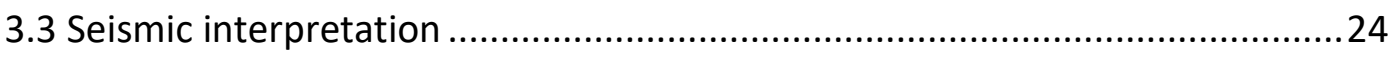

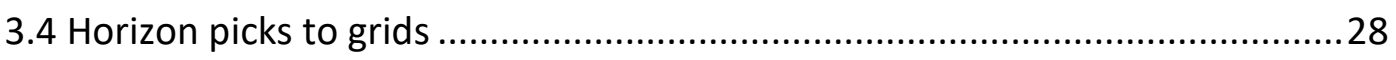




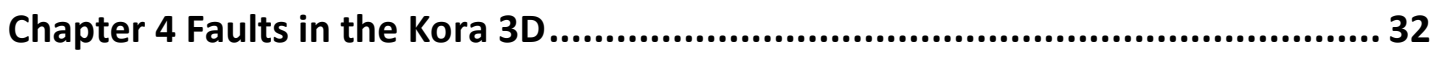

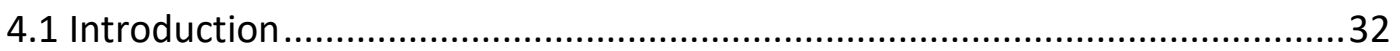

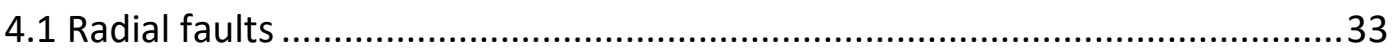

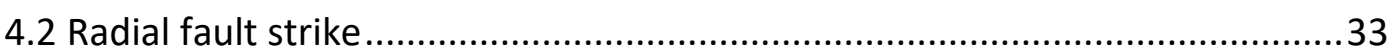

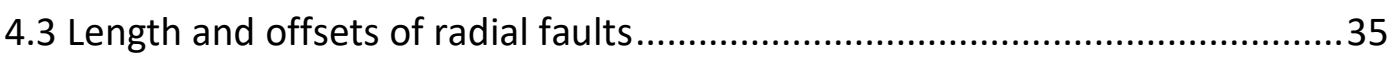

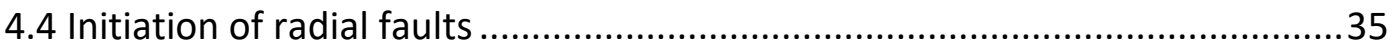

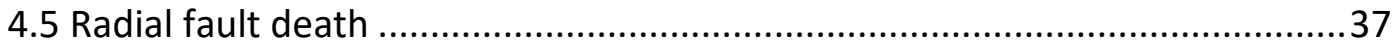

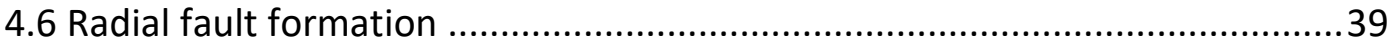

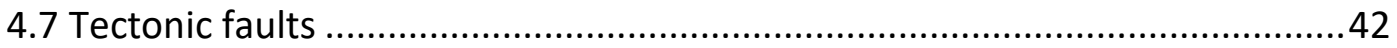

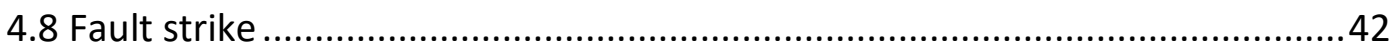

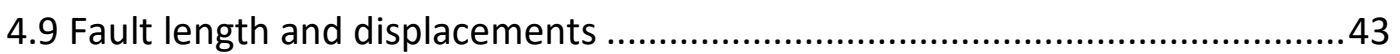

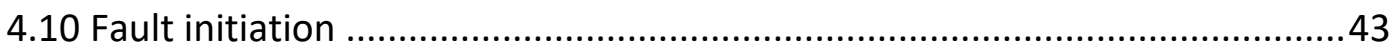

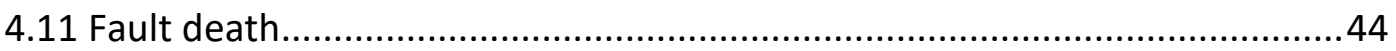

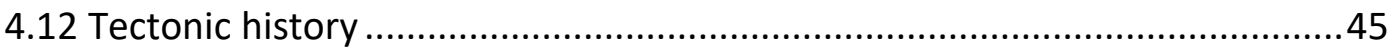

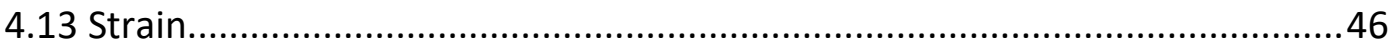

4.14 Decollement and mass transport complex ...............................................48

4.15 Faults and hydrocarbon prospectivity .......................................................5

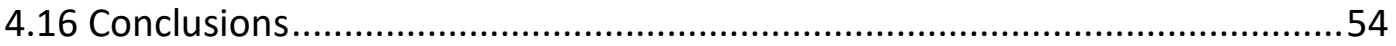

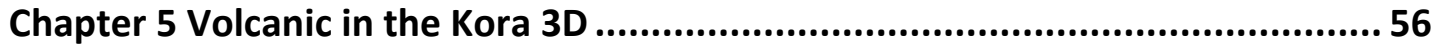

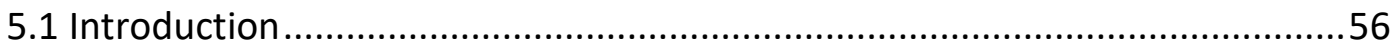

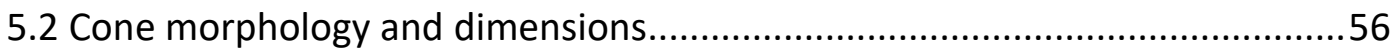

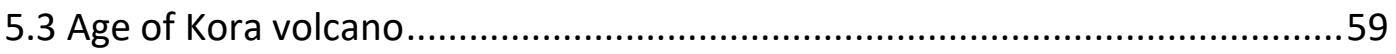

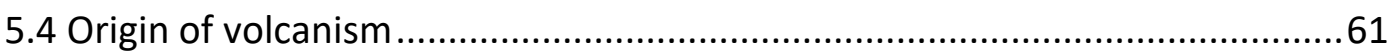

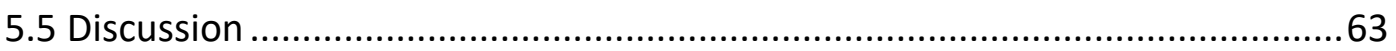

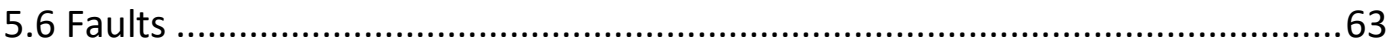


5.8 Conclusions

Conclusion.

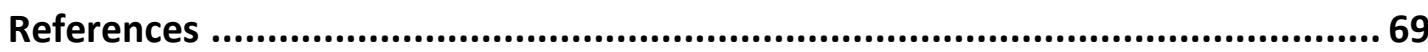

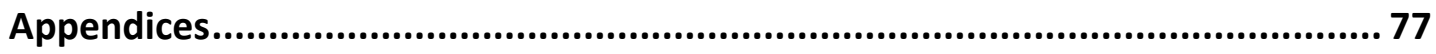

Appendix A- Kora 3D Acquisition Parameters..................................................77

Appendix B- Time Depth Curves for Wells Used and Nearby Wells ......................78

Appendix C- Well Data Table ........................................................................ 79

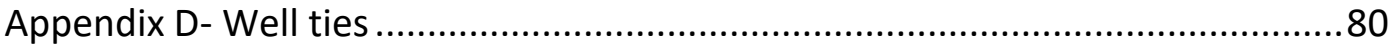

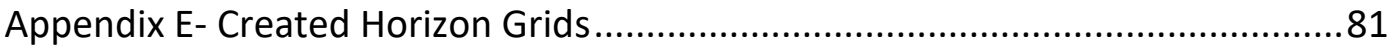

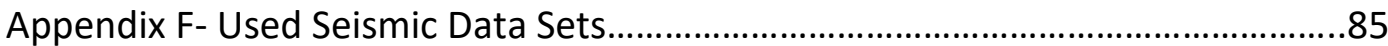




\section{Table of Figures}

Figure 1.1 Location of 3D seismic surveys in the Northern Taranaki region including

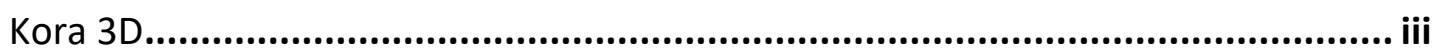

Figure 1.2 A time slice of the Kora 3D seismic data ............................................. 2

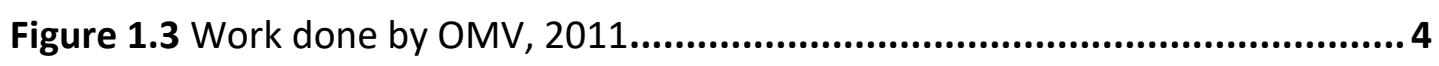

Figure 1.4 Work done by Giba, et al., 2010 ...................................................5

Figure 2.1 The Tectonic setting of Zealandia................................................9

Figure 2.2 Tectonic elements of the Taranaki Basin......................................... 11

Figure 2.3 Block rotation model for the Taranaki Basin from Miocene to recent.... 14

Figure 3.1 Well tie locations in map view................................................. 29

Figure 3.2 Map view of strain profile calculation grid ......................................... 30

Figure 3.3 Strain Profiles for all mapped horizons ......................................... 31

Figure 4.1 The map view of distribution and orientation of normal faults within the

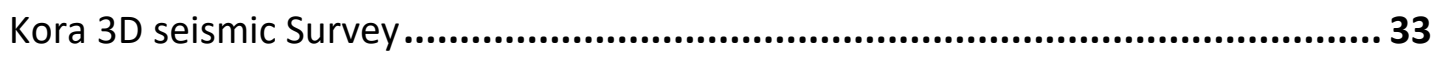

Figure 4.2 Rose diagram showing the strikes of mapped radial faults within the Kora

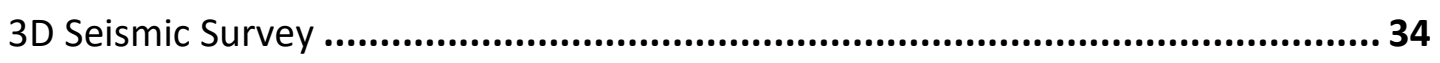

Figure 4.3 Ages of initiation for normal faults within the Kora 3D ....................... 36

Figure 4.4 Growth profiles for five radial faults ............................................ 37

Figure 4.5 Map of fault death ages................................................................... 38

Figure 4.6 Simplified cartoon cross section for radial faulting in model 1 ............ 40

Figure 4.7 Simplified cartoon cross section for radial faulting in model 2 .............41 4

Figure 4.8 Rose plot of the strikes of the tectonic normal faults within the Kora 3D

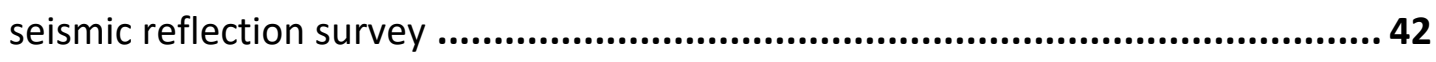

Figure 4.9 Growth curves for the tectonic faults that displace the volcanic edifice $\mathbf{4 4}$

Figure 4.10 Strain profiles for mapped horizon within the Kora 3D .................... 47 
Table 4.11 Horizons and corresponding strain summation measurements for corresponding horizon

Figure 4.12 Seismic characteristics of the decollement

Figure 4.13 Seismic characteristics of the MTC and the decollement surface on the western flanks of the volcanic cone

Figure 4.14 Extent of the mapped decollement feature 50

Figure 4.15 Cross section across the Kora prospect modified from OMV PR report 4318 (2011).

Figure 4.16 Maps showing the fetch size for two possible Kora prospects considered by OMV 54

Figure 5.1 3D model of the Kora volcanic cone and intersecting normal planes .....57

Figure 5.2 Map view of interpreted volcanic cone and intersecting faults 58

Figure 5.3 Seismic inline showing cross-section of volcanic cone and the cones relationship with surrounding sediment 60

Figure 5.4 Map view of interpreted volcanic cone and intersecting faults 66

\section{Table of Appendix Figures}

Appendix A1. Kora 3D acquisition parameters 77

Appendix B1. Time Depth Curves for used and nearby wells 78

Appendix C1. Table of wells used 79

Appendix D1. Well tie between Kora-1 and Ariki-1 80

Appendix D2. Well tie between Kora-1 and Tangaroa-1 .................................... 81

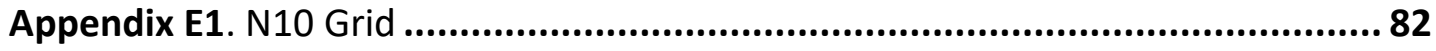

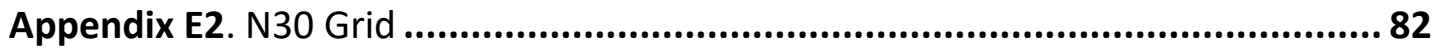

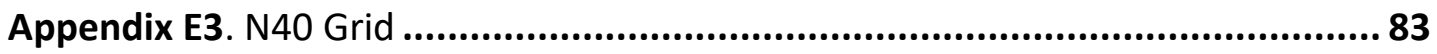




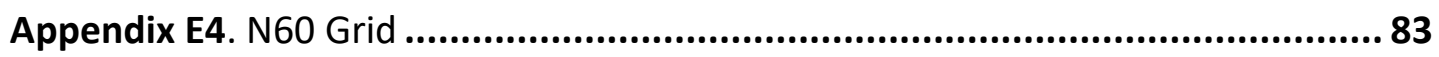

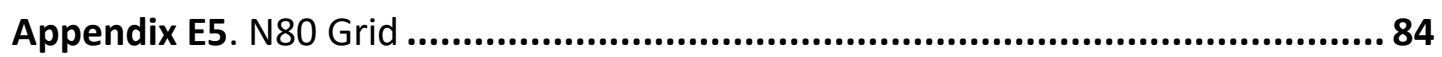

Appendix F1. Table seismic lines and surveys used in this study ..........................85 


\section{Chapter 1}

\section{Thesis introduction}

This Project uses and interprets the Kora 3D seismic data, and surrounding 2D seismic lines. This study aims to constrain already-mapped geological interpretation, create new seismic interpretation, and draw conclusions on volcanic activity and its relationship (or lack of) with normal formation and timing. The Kora 3D seismic volume is located in the Northern region of the Taranaki Basin (Fig. 1.1). The Northern Graben characterizes this region of the basin (King \& Thrasher, 1996). The formation of Northern Graben created accommodation space, this accommodation space accompanied with high influx of sediment into this region from the Mid Miocene to Recent ( $<16 \mathrm{Ma}$ ) led to preservation of fault activity in this area (King \& Thrasher, 1996; Giba, et al., 2010; 2013). Kora 3D is one of several 3D seismic volumes in this basin, and has four wells located inside (Kora 1A-4). The four wells are clustered around a volcanic edifice located in the middle of the survey (ARCO Petroleum NZ Inc., 1988). Kora $1 \mathrm{~A}$ encountered an oil discovery which is to this day, still a viable oil prospect (ARCO Petroleum, 1988).

The Kora 3D seismic survey was acquired in 2005/06 by OMV and covers an area of $750 \mathrm{~km}^{2}$ (OMV New Zealand Ltd, 2011) (acquisition parameters can be found in Appendix A). The Kora 3D has 4.5 seconds of usable two way travel time (TTWT) data, and is located on the western edge of the Northern Graben. Extensive work has been undertaken by OMV since 2006, including basin modelling and prospect mapping (OMV New Zealand Ltd, 2011). As the seismic data are 3D, these give us an extreme amount of detail to work with when compared with 2D data. The 3D feature allows us to view the data as a horizontal time slice or in a vertical/cross sectional view (Fig 1.2). The line spacing of this data set is 12.5 meters while in conventional $2 \mathrm{D}$ it can range between $20-50$ meters. The attributes of a $3 \mathrm{D}$ seismic data set allow for a greater resolution data set, which is more valuable for research and petroleum 
assessment. Acquired data that can be freely accessed on the New Zealand Petroleum and Minerals database, known from here on in as NZP\&M, was used in this study. The data base can be accessed freely due to New Zealand Government 5 year relinquish period, as per the Crown Mineral Act 1991 (New Zealand Government, 1991)

Normal faulting and volcanism are observed to have been active from the Late Miocene to Recent at the Northern end of the Taranaki Basin (OMV New Zealand Ltd, 2011; Giba, et al., 2012; 2013). Determining the impact that volcanism and faulting had on one another within the Kora 3D is a key aim of this study.

The main source rock in this area is Palaeocene organic rich marine rock called the Waipawa formation (ARCO Petroleum, 1988; OMV New Zealand Ltd, 2011). This formation is kerogen type 2, which is arguably more oil prone than that of the Cretaceous coals (Rakopi formation) from further south in the basin (Killops, et al., 1994; New Zealand Petroleum and Minerals, 2014).

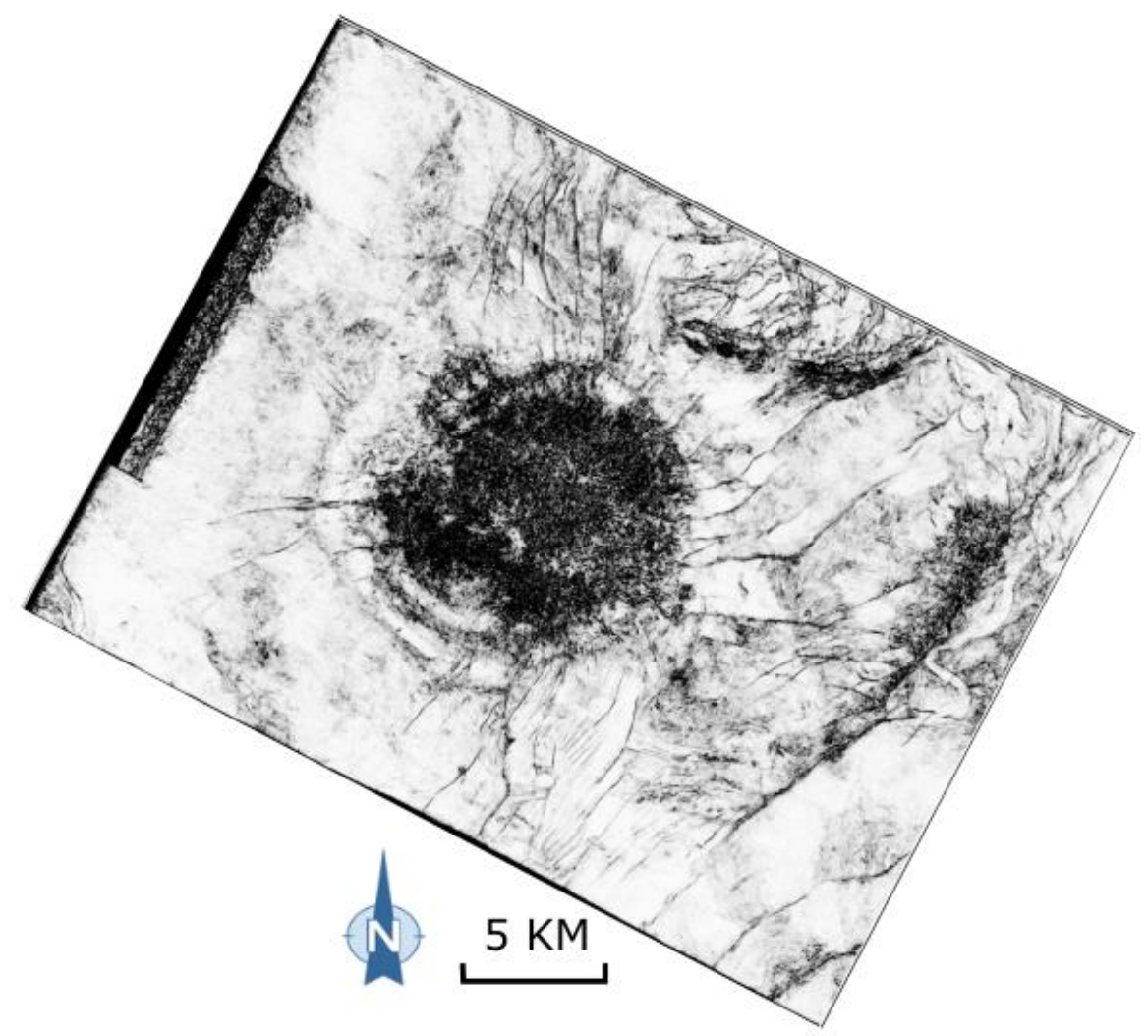

Figure 1.2. A time slice of the Kora 3D seismic data. This is an example of the free data available. 


\subsection{Rationale}

This project is relevant for a number of reasons. The principal importance comes with reducing uncertainty that significantly plagues the oil and gas (Lerche, 1997). The biggest uncertainty in the oil and gas industry is the geological interpretation of geophysical data, and the fact many prospects rely on this interpreted information. Any information gathered on the subsurface will decrease geologic uncertainty for the industry. This project better constrains the already mapped horizons and adds to the detailed horizons. In addition, the study will map faults and the volcanic edifice in more detail. Detailed mapping of these features is key to this research.

Expanding underpinning knowledge in this area is another reason why this work is of significance. An expansion of knowledge has always been welcome to the petroleum industry. The industry is regarded as being at the forefront of technology and is highly evolved. To keep its competitive edge, the industry in New Zealand needs new knowledge - re-evaluation of data will entice growth and keep New Zealand on the global map in terms of quality and safe oil and gas production. Using the 3D seismic data to our benefit is a great opportunity to extract new knowledge.

The particular area of focus for this study has also seen some interest in terms of prospectivity. An oil prospect was discovered in 1988, and some geophysical leads have been identified in the seismic volume since (ARCO Petroleum, 1988). More detailed information regarding the age, location, and interaction of geophysical horizons, faults, and volcanic processes will result in increasing the potential value of the Northern Taranaki basin to any overseas developers. 


\subsection{Previous work}

There are two prior principal contributors of work in the area of interest. Work has been done by academic researchers (Geological Nuclear sciences, University of Dublin, and Victoria University of Wellington) looking at the normal faulting, volcanism, and subduction process in this area and over a larger Taranaki context. While OMV, the company that obtained the data back in $2005 / 06$, have done extensive work, the work was aimed at producing a basin model and to look at fluid movements along faults (OMV New Zealand Ltd, 2011).

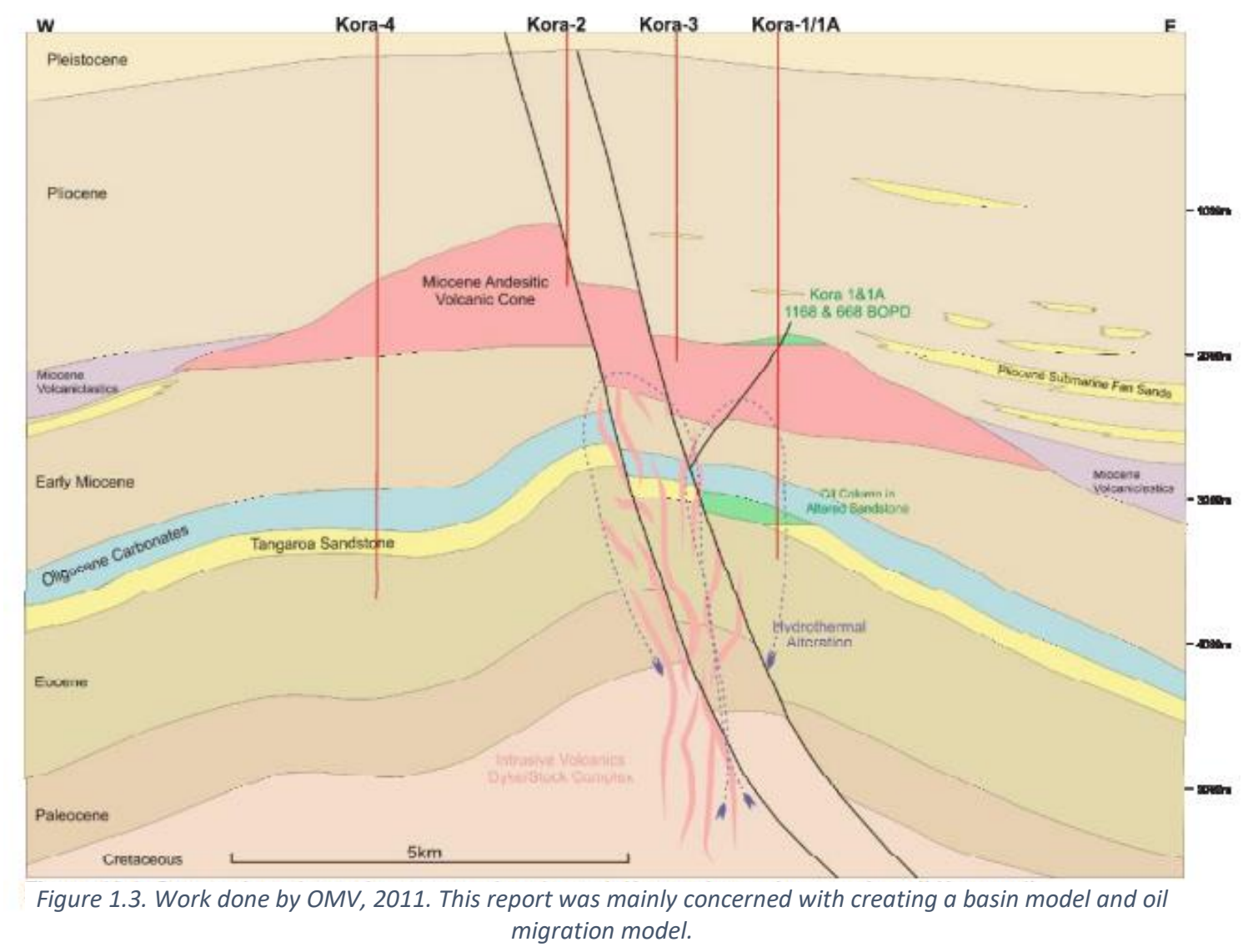

Other previous work has likewise been done by oil companies, mainly concerning the four wells and oil discovery by ARCO Petroleum (ARCO Petroleum, 1988).

OMV has produced a number of petroleum reports, which are all available on the NZP\&M website. The number of the reports are 4313 and4318 (Clayton, 2011; OMV New Zealand Ltd, 2011). These Petroleum Reports (PR) outline what OMV did over their time as holder of the prospecting permit (PEP) (until 2009), and encapsulates the previous work done on all four Kora wells. The reports cover the conceptual 
elements of the petroleum system, mainly focusing on oil migration and accumulation for viable prospects (Fig. 1.3). The overall aim of OMV's work was to create a basin model regarding thermal maturity and oil migration. OMV did not closely look at the relationships between volcanism and faulting, which will be undertake here. This work by OMV will provide a base, from which to launch this research. It will also be of value and of interest to add to the knowledge regarding petroleum prospectivity.

Previous analysis by M. Giba and colleagues (Giba, et al., 2010; 2012) evaluated the relationship of normal faulting and volcanic migration through the Northern Taranaki region (Fig. 1.4). They took a basin wide approach over a time period of $16 \mathrm{Ma}$ till present. They came up with the observation that the volcanism slowly migrated southwards, while faulting had a punctuated migration. Overall no relationship was observed between volcanism and faulting over this time period. There was, however a conclusion drawn on the greater tectonic process. Giba, et al., considered that the process of slab roll back and rotation was the cause of this normal faulting and volcanic migration. This work was done over a wide area. Looking at the Kora 3D in more detail, this work better constrains these ages, and re-evaluates the conclusions given by Giba, which provides a good starting point.

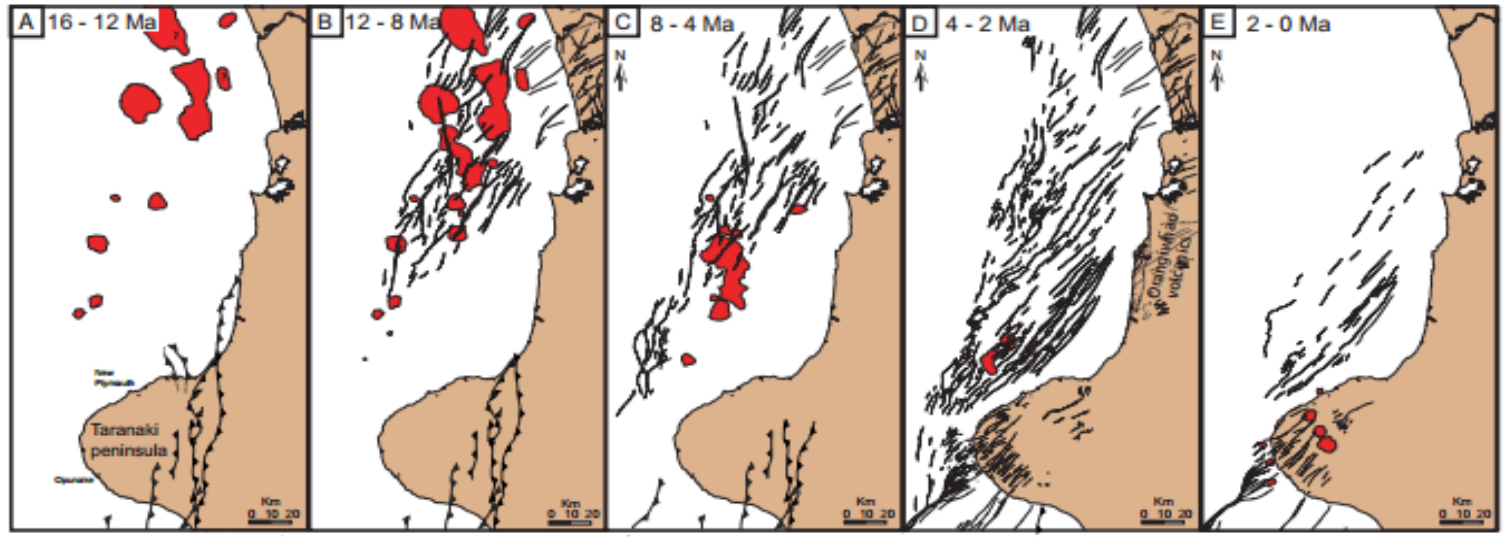

Figure 1.4. Work done by M. Giba 2013. Migration of faults and volcanism can be seen in this figure.

Other previous work involves Stern, et al., (Stern, et al., 2013), and well completion reports from 1988 and 1985 (ARCO Petroleum NZ Inc., 1985; ARCO Petroleum NZ Inc., 1988a; ARCO Petroleum NZ Inc., 1988b; ARCO Petroleum NZ Inc., 1988c). The well reports were purely produced to attain information on oil prospectivity. They contain detailed stratigraphic columns, including lithostartigraphy, biostratigraphy, 
and tephra layers. Stern et al 2013., again looks at a large North Island context, and gives a novel approach to understanding the process producing migration of depocenters and faulting. Stern et al 2013., puts the migration of normal faulting down to mantle instability.

Even though past work has been published in this area and topic, the valuable preceding work leaves opportunities for further research and more detailed analysis that undertakes and utilizes the existing work to expand the knowledge in this important area.

\subsection{Nomenclature}

3D Seismic Reflection Volume: A 3D Seismic Reflection Volume is created by shooting a series of parallel 2D seismic reflection lines with minimal spacing between each line (usually 16.5 meters). Geometry techniques covert the 2D lines into a 3dimensional volume. The volume is viewed using the reflection of sound. The 3dimensional aspect of the volume allows the viewer to view in any direction they please, a major benefit being the time slice direction.

Seismic Coherency: Seismic coherency is the measurement of a seismic trace compared to the traces immediately surrounding it. If the traces signature is similar they are called 'coherent', if not they are labelled 'disruptive'. This process uses a user defined window of traces to compare to the selected trace. This approach of viewing seismic reflection data can allow the user to easily spot faults or volcanic features as they will have a disruptive signature.

Seismic Section: Seismic sections are images displaying seismic, such as a 2D seismic profile or a profile extracted from a 3D seismic volume in the vertical orientation.

Seismic Time-Slice: Seismic time-slices show reflection data from every trace with the same TWTT. They are viewed as horizontal planes and represent a similar depth throughout the subsurface.

Seismic Stratigraphy: Seismic stratigraphy is mapping stratal surfaces and stratigraphic units using reflection geometry (on lapping, down lapping), seismic attributes, and seismic signature. This is a powerful tool in seismic mapping, which 
allows the user to split the seismic reflection profile into seismic facies or stratigraphic units.

Growth Faults/ Syn-sedimentary faults: These faults are extensional faults, which are in the presence of a large amount of sedimentary supply. The strata on either side of the fault plane has different geometry and thickness, this is driven by the large amount of sediment supply and the accommodation space created by movement along the fault plane. Movement along the fault planes can either be driven by difference in sedimentary load, or the surrounding stress field. These faults provide a good record of fault movement.

\subsection{Layout of chapters}

Chapters in this thesis are laid out in terms of geological features and ideas. There are two main discussion and results chapters; one for faults mapped within this study, and one focusing on the kora volcanic cone. Aside from these two main chapters, there is a background chapter that discusses the current state of knowledge on the wider Taranaki Basin, and a methodology chapter.

The two main results and discussion chapters are each laid out with a combined results discussion format. Each geological idea in these two chapters is shown as a result, discussed individually, and then followed by a discussion of the larger geological setting. 


\section{Chapter 2}

\section{Geological background}

\subsection{Introduction}

The Taranaki Basin is located on the western side of New Zealand's North Island, situated on the overriding Australian plate (Fig 2.1). The basin is roughly $100,000 \mathrm{~km}^{2}$ in size (King \& Thrasher, 1996). The basin has been a passive margin basin for most of it's life (King \& Thrasher, 1996). The Taranaki basin encompasses both onshore Taranaki peninsula, and offshore continental shelf. The basin extends from the top of the western South Island to the west coast of Auckland City (Fig 2.2). Overall, the basin extends approximately $450 \mathrm{~km}$ along the western margin of New Zealand. The basin is made up of smaller depo centres and sub-basins that cover the length of the basin (Stern \& Davey, 1990; King \& Thrasher, 1996). The oldest sediment in the basin is late Cretaceous ( 84 million years), and in some locations of the basin the sediment is $8 \mathrm{~km}$ thick (King \& Thrasher, 1996). The tectonic history of the basin varies with location and three main tectonic episodes identified:

- Late Cretaceous to Palaeocene extension.

- Eocene to recent shortening in the southern portion of the basin.

- Miocene to recent extension in the northern part of the basin.

\subsection{Contemporary subduction system}

The continent of Zealandia spans across the Australian Plate and the Pacific Plate (Fig 2.1). The plate boundary is complex, created by the relative motions of the plates to one another. In the North, the Pacific Plate subducts underneath the Australian Plate at $\sim 42 \mathrm{~mm} / \mathrm{yr}$ (Giba, et al., 2010). In the south, the reverse occurs; with the Australian plate subducting eastwards underneath the Pacific plate at $35 \mathrm{~mm} / \mathrm{yr}$ (Giba, et al., 
2010). In between lies a major strike slip fault, the Alpine Fault, which along with the other major strike slip faults in the area (Hope fault, Kekerengu fault) accommodates much of the oblique movement between the two plates. The semi dashed line on figure 2.1 shows the Alpine fault. The complexity of the plate boundary is a direct result of the location of the relative Pacific-Australian Euler pole (King, 2000). The location of the Euler pole gives a wide range of oblique and normal plate movements along the plate boundary (King, 2000).

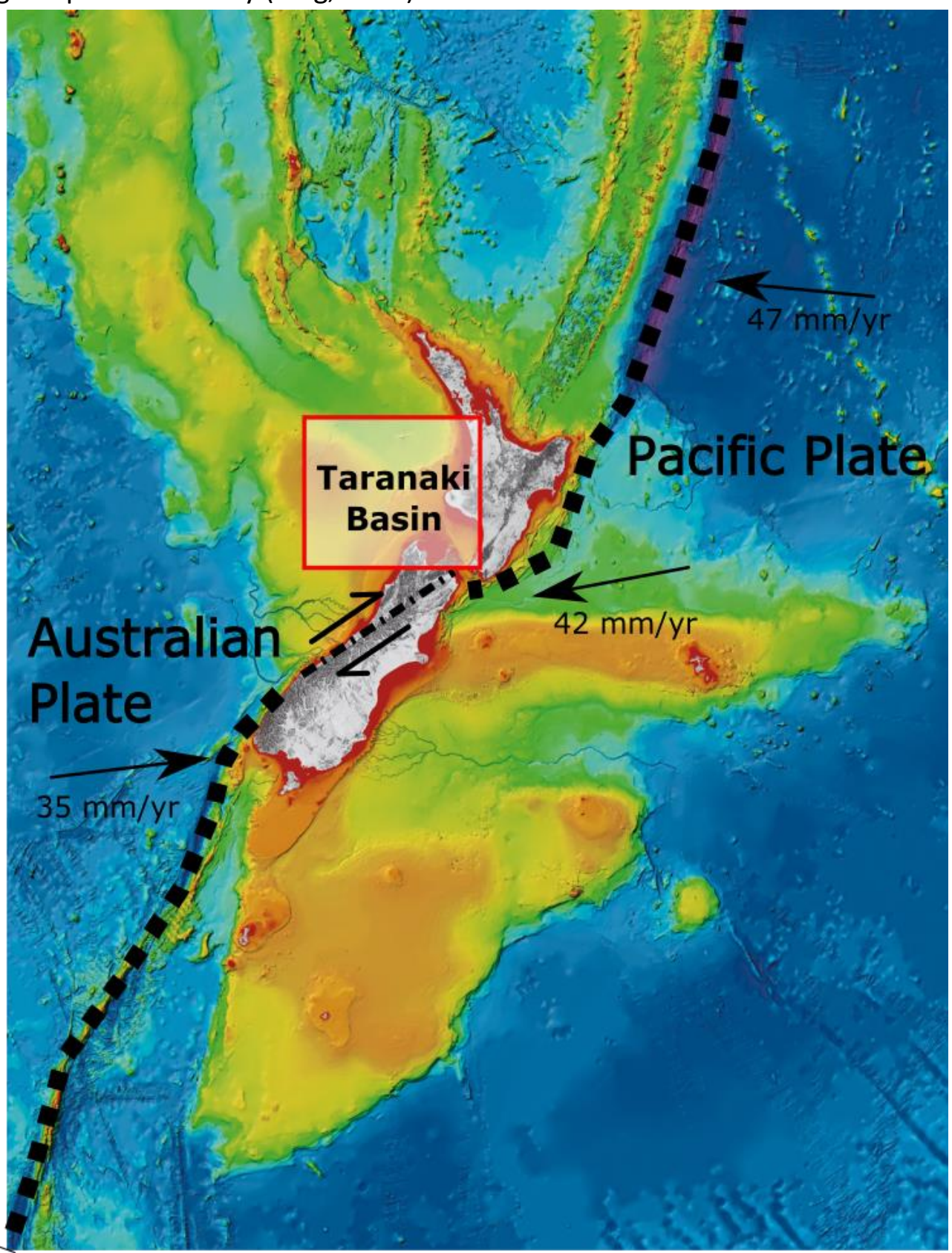

Figure 2.1. The Tectonic setting of Zealandia. The Plate boundary is marked with a black dashed line. Alpine Fault is shown with semi-dashed line with relative movements annotated. Plate movements are denoted with arrows showing relative movements from Giba, et al., 2010. Taranaki Basin location shown by red box. Bathymetry is depicted with colours (red low water depth, blue high water depth). Figure is modified from NIWA map (https://www.niwa.co.nz/blog/multibeam-mappingof-the-seafloor). 
The North Island subduction system, however, is not as simple as a two dimensional model. Modern siesmological imaging and geodetic databases has allowed two contrasting sytems to be distinguished (Stern, et al., 2006). In the upper half of the North Island (Taranki and above) we have what is categorised as a "Mariana" type system with back arc extension, volcanism, and high heat flow (Stern, et al., 2006). In the southern half of the North Island subduction zone (Wanganui) there is "Chillian" type sytem, with compresion, thickned lithospehe, and low heat flow (Uyeda, 1982; Stern, et al., 2006).

\subsection{Tectonic history}

The complexity of the recent and past plate movements as outlined by King (2000), has created a somewhat intricate tectonic history of the Taranaki basin. The basin is considered a passive margin Foreland basin, as parts of its geological history are tectonically quiet, such as the late Cretaceous and the Eocene (Stern, et al., 2006; King, 2000). In contrast, during the Mid-Late Cenozoic period, the basin was located on the periphery of the Australian Plate and Pacific Plate margin, this led to a tectonically active basin (King \& Thrasher, 1996).

Due to the complex geological history, the basin can be split into two sections; the Eastern Mobile Belt and the Western Stable Platform (King \& Thrasher, 1996)(Fig 2.2). As the name suggests the Western Stable Platform has a relatively (when compared to the Eastern Mobile Belt) tectonically quiet past. The Eastern Mobile Belt has been effected in the past and more recently by active deformation. This can be seen in figure 2.2 , with a large number of active faults present in the area of the Eastern Mobile Belt. From this point onwards, I will be focusing my tectonic history on the Eastern Mobile Belt. 


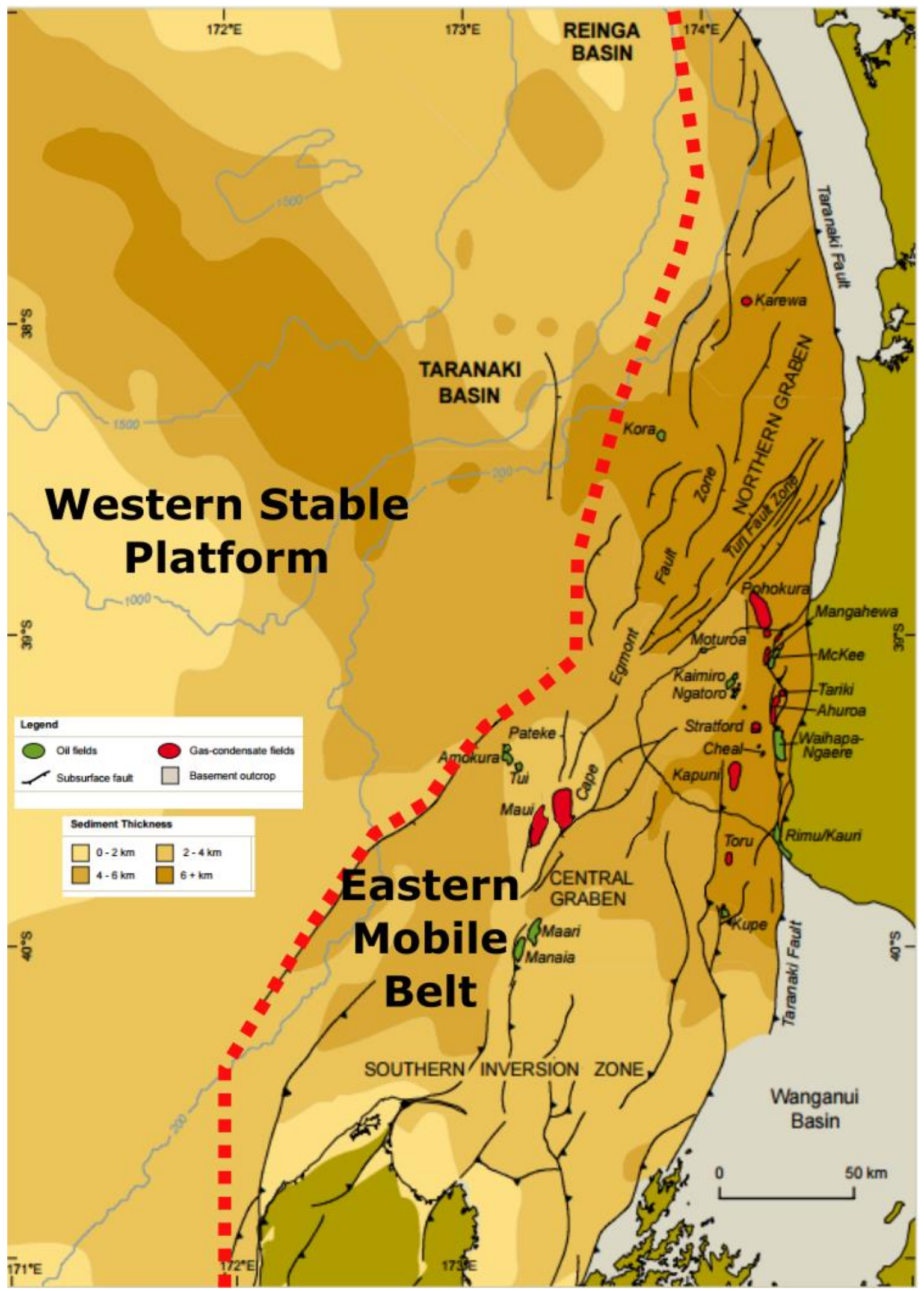

Figure 2.2. Tectonic elements of the Taranaki Basin. This figure shows the boundary between the Western Stable Platform and the Eastern Mobile Belt. This figure also shows the location of producing and known oil and gas reserves within the basin, sediment thickness, and sub basins such as the Northern graben and Sothern inversion zone. Figure has been modified from NZP\&M Taranaki Basin fact file (http://www.nzpam.govt.nz/cms/investors/doc-library/petroleumbasins/taranaki-basin-factsheet.pdf). 
Three tectonic episodes have been identified within the Eastern Mobile Belt of the Taranaki Basin. They included, Late Cretaceous to Palaeocene extension, Eocene to Recent shortening in the southern portion of the basin, and Miocene to Recent extension in the northern part of the basin (Holt \& Stern, 1994; King \& Thrasher, 1996; Giba, et al., 2010; New Zealand Petroleum and Minerals, 2014).

The early history of the Taranaki basin begun as a rift during the separation of Gondwanaland (King, 2000). Normal faults fashioned horst and graben features within the basement rock, which created accommodation space allowing sediment to fill the empty space. The normal faults generally strike in the north-south direction, with throws up to $3 \mathrm{~km}$ (King \& Thrasher, 1996). Normal faults accommodated most of the extension associated with this period (King \& Thrasher, 1996; Giba, et al., 2010). This extension fully ceased in the Palaeocene, with the locus of extension migrating to the west; leading to the opening of the Tasman Sea (King \& Thrasher, 1996). The Cretaceous normal faults today may be reactivated as reverse faults in the southern portion of the basin, and normal faults in the northern Portion (King \& Thrasher, 1996; Giba, et al., 2012). These reactivated Cretaceous faults accommodate part of the extension and compression in the Miocene to recent time period (Giba, et al., 2010; 2012).

During the Eocene and Oligocene, there was a period of little tectonic action. The only exception to this was shortening occurring mainly in the southern portion of the Eastern Mobile Belt (Stern \& Davey, 1990; Holt \& Stern, 1994). This shortening created the Taranaki Fault (Stern \& Davey, 1990; Holt \& Stern, 1994; King \& Thrasher, 1996). This shortening and crustal deformation accommodated by the Taranaki Fault caused subsidence to occur west of the fault, this occurs due to loading and flexural deformation (Holt \& Stern, 1994). At this moment in geological time, Stern \& Davey, 1990, categorised the Taranaki Basin as a foreland basin.

Subduction commenced forty million years ago (King, 2000; Stern, et al., 2006; Giba, et al., 2010), with the Pacific Plate obliquely subducting underneath the Australian Plate in a southwest direction. This subduction firstly resulted in compression throughout the basin. Later $(\sim 12 \mathrm{Ma})$ the subduction process caused both compression, and extension in the southern, and northern portion of the basin 
respectively (King \& Thrasher, 1996; Giba, et al., 2010). A rotating subducting slab is thought to have been the cause of simultaneous extension and compression through the Taranaki Basin (Fig 2.3) (King \& Thrasher, 1996; Giba, et al., 2010). Rotation of the subducting slab was thought to hit a peak of rotation at $3^{\circ} / \mathrm{my}$ (Giba, et al., 2010). This rotating slab model was depicted in Giba, et al., 2010 (Fig. 2.3), and was first introduced by King and Thrasher, in 1996. As the basin evolved the rotation axis, which marks the difference between extension and compression migrated southwards. This rotation of the North Island was thought to be due to either slab rollback and/or slab steepening, or a continental collision with the buoyant continental crust of the Chatham Rise at the Hikurangui southern margin (King \& Thrasher, 1996; Seebeck, et al., 2014). It is estimated that $7 \mathrm{~km}$ of shortening occurred in the southern part of the basin, and $2-3 \mathrm{~km}$ of extension and crustal thinning in the north (King \& Thrasher, 1996; Giba, et al., 2010). This active tectonic episode created two well-known sub basins within the Taranaki basin, the Southern Inversion Zone and the Northern Graben (New Zealand Petroleum and Minerals, 2014).

The Northern Graben geological history is somewhat different from the rest of the surrounding basin. The graben has a width ranging from $40-60 \mathrm{~km}$ and is defined by over 300 faults and a number of sub-basins (Giba, et al., 2010). The graben runs along the axis of the Taranaki basin, with an asymmetric east-west profile. On the westward margin of the graben there are large offset faults, many with vertical displacements over 500m (Giba, et al., 2010; 2012). The large faults are commonly are partitioned or segmented (Giba, et al., 2010; 2012; Johnston, 2014). While on the east, it is more common to have straight fault planes with less relative displacement (Giba, et al., 2010; 2012). A large majority of the faults within the graben have a common strike of N-S or NE-SW (Giba, et al., 2013). It is debated whether or not the normal faults within the graben contain any right lateral strike slip component. Following experiments done on stress indicators within boreholes (borehole breakouts) (Anderson from Giba, et al., 2010) to determine recent regional strain rates, indicated that the extension was mainly NW-SE, leading to little lateral movements on the faults within the graben. The amount of extension within the graben is higher in the north and decreases as you move south (Giba, et al., 2010). This observation ties in 
well with the idea of plate rotation as mentioned previously (Fig 2.3) (Giba, et al., 2010). It is widely believed that the normal faults in the northern graben formed in a back arc setting and are related to the subduction process (Stern \& Davey, 1990; King \& Thrasher, 1996; Giba, et al.; 2010; 2013).

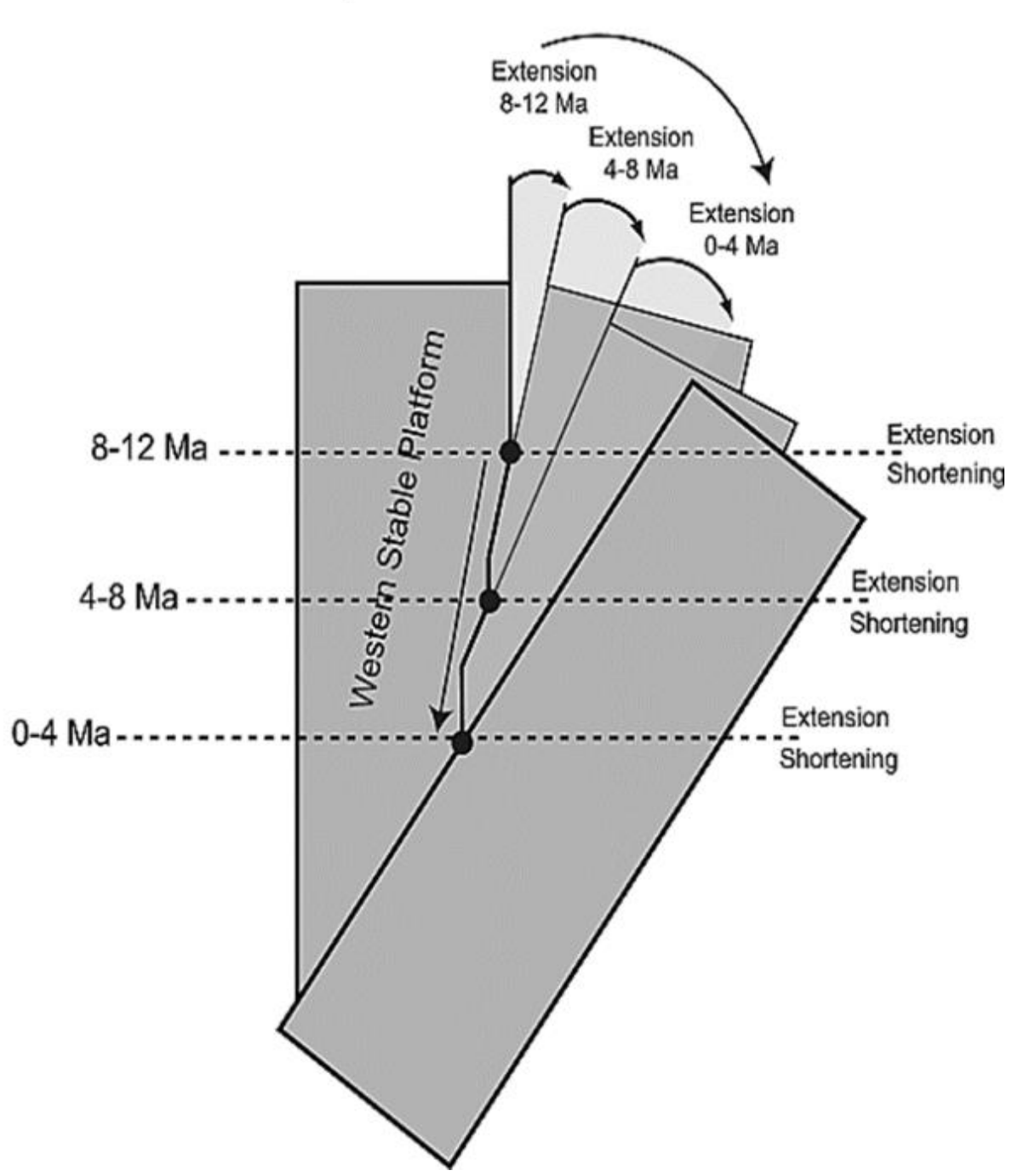

Figure 2.3. Block rotation for the Taranaki Basin from Miocene to recent. This model is similar to one proposed by King and Thrasher (1996), however, this includes a migration of rotational axis over time. Figure modified from Giba et al., (2010). 


\subsection{Volcanism in the Northern Graben}

Volcanism first occurred in the Taranaki basin 16 million years ago and still occurs today (Ballance, 1975; Bergman, et al., 1992; Giba, et al., 2010; 2013). The volcanism within the Northern Graben is correlated with the initiation of extension both in location and in timing (Giba, et al., 2010; 2013). The volcanic structures in the Northern Graben formed because of the westward subducting Pacific Plate underneath the Australian Plate (Bergman, et al., 1992; King \& Thrasher, 1996; Seebeck, et al., 2104). The volcanic features within the Northern Graben are mainly comprised of submarine strata volcanism. Volcanic features of the Northern Graben are labelled the Mohakatino volcanics (King \& Thrasher, 1996). It was first thought that back arc processes with evidence of high potash andesites, formed these volcanic features within the Northern Graben (King, 1990; Bergman, et al., 1992). From the Kora wells (Kora-1A, 2, 3, 4), Bergman, et al., (1992), have shown that the andesites of Kora are normal calc-alkalic indicative of intra-arc basin processes, and this can also be assumed for the rest of the Mohakatino volcanics. This has been interpreted to mean that more than one arc may have been present during this time (Ballance, 1975; King \& Thrasher, 1996).

\subsection{Southward migration of faulting and volcanism}

The migration of active faults and the volcanic arc has been observed and studied for a long time (King \& Thrasher, 1996; Stern, et al., 2006; Giba, et al., 2010; 2013). High sedimentation rates and oil and gas industry seismic reflection studies, allows the examination of both the timing and evolution of faults and volcanism throughout the length of the Taranaki Basin.

When fault displacement and timing are examined, large quantities of sediment allow us to accurately deduce the growth structure of a particular fault plane. Giba, et al., (2010) \& Giba, et al., (2013), show normal faulting that has migrated from the north to the south of the Taranaki Basin (Fig 2.4). Onset of normal faulting occurred $\sim 12 \mathrm{Ma}$ in the north of the basin and migrated southward, to just south of the 
Taranaki Peninsula (Reilly, et al., 2015). During this time a 20-degree clockwise change in the direction of extension also occurred (Giba, et al., 2010).

The southwards migration of normal faulting happened geologically instantaneously, and moved in a stepwise fashion (Giba, et al., 2010). This interpretation however, depends on the temporal resolution of the data; yet, at this point there seems no reason to doubt this.

Migration of faulting mainly occurred due to the block rotation as depicted in figure 2.3. This is a widely accepted model and is supported by GPS data and palaeomagnetism (Stern, et al., 2006).

It has also been noted that the volcanic arc migrated southwards since $20 \mathrm{Ma}$ (Giba, et al., 2010; 2013; Seebeck, et al., 2014). Volcanism throughout the North Island mainly formed above the subducting plate, as observed from chemical analyses (Bergman, et al., 1992; Seebeck, et al., 2014). Therefore, knowing the age and location of volcanic events give us insight into the past geometry of the subducting plate. Giba, et al., (2010), complied a data list of ages of volcanic features throughout the Taranaki basin. Volcanism pre dated faulting at the northern tip of the basin, while in the south the opposite is true (Giba, et al., 2010). This change in relative timing and volcanic centre initiation dates show that volcanism migrated at a more gradual rate when compared to the normal faulting.

There are a number of hypothesis of why this is occurring. The main two consist of slab rollback and/or slab steepening accompanied with changes in mantle flow and migration of the southern termination of the subduction system (Giba, et al., 2010) (Seebeck, et al., 2014), or a Rayleigh-Taylor mantle instability (Stern, et al., 2006). Both of these ideas allow rapid migration of erratic intra-arc structures, and southward migration of volcanic and tectonic features (Stern, et al., 2006; Giba, et al., 2010). These hypotheses also allow for the 'three dimensional' architecture the North Island subduction system has. 


\section{$\underline{2.5 \text { Kora volcano }}$}

The Kora volcanic edifice is located within the Northern Graben and has an approximate initiation age of 20-18 Ma (Bergman, et al., 1992). Kora magmatism is thought to be long lived when compared to surrounding past and recent volcanism, both in the Taupo Volcanic Zone and Taranaki Regions. Bergman, et al., (1992), stated that the magmatism associated with Kora has a time span of $10 \mathrm{Ma}$, which was determined using biostratigraphic and geochronological dating methods from the Kora Wells. The magmatism began during the Early Miocene and did not become extrusive until 15-17 Ma (Bergman, et al., 1992). The youngest tuffs recorded in the Kora wells have ages of 8-11 Ma (ARCO Petroleum, 1985). The Giant Forsets formation has since completely buried the volcanic edifice.

Using Sr-Nd isotopes Bergman, et al., (1992), determined that the melts from the Kora magmatism came from depleted mantle, and had little interaction with seawater or radiogenic crust. The melts for Kora are indicative of subduction related volcanism, with normal calc-alkalic andesites. This led to the conclusion that Kora magmatism was intra-arc magmatism, rather than back arc magmatism. Within the volcanic complex there is little variance in mineral composition (Bergman, et al., 1992). Kora andesites are similar to the Northland Volcanics (Smith et al, 1989).

In the past (ARCO Petroleum NZ Inc., 1988), and more recently (OMV New Zealand Ltd, 2011) the Kora volcanic edifice has been a subject of oil and gas exploration. It is thought that migration of oil occurred from the Miocene to Recent through the present day fault zones (Bergman, et al., 1992; OMV New Zealand Ltd, 2011). Trapping of the oil would not have occurred until 2-4 Ma with the complete burial of the volcanic edifice (OMV New Zealand Ltd, 2011). The volcanic edifice can act as a stratigraphic trap of hydrocarbons, but Kora lacks the seal necessary to trap an economic quantity of hydrocarbons (OMV New Zealand Ltd, 2011). The seal is the overlying Giant Forsets Formation with a thickness of $1.2 \mathrm{~km}$. This formation can hold a hydrocarbon column of 40-120 m (Bergman, et al., 1992), as tested by capillary pressure measurements from well Kora- 2 . 
The main reservoir rock is pyroclastic and epiclastic in nature. These lithologies can sometimes form channels dispersing radially form the apex of the cone (Bergman, et al., 1992). Porosity of reservoir rock is $6 \%$, and mainly comes in the form of micro porosity and fractures within the Tuffs (Bergman, et al., 1992). Within the edifice, there are also layers of impermeable silt and mud deposits, which may act as seals (Bergman, et al., 1992; OMV New Zealand Ltd, 2011).

\subsection{Kora wells}

Kora 1 was drilled in November 1987, and Kora 1A was drilled in February 1988. Both are located in the Tasman Sea $78 \mathrm{Km}$ north west of New Plymouth on the southeastern flanks of the Kora volcanic edifice. The wells were drilled in $122.83 \mathrm{~m}$ of water depth, and (ARCO Petroleum, 1988).

Kora 1 was drilled to a depth of $3421 \mathrm{~m}$ in 38 days. The target of this well was to reach the Eocene age Tangaroa sandstone that had been encountered in both the nearby wells, of Ariki 1 and Tangaroa 1. Kora 1 showed both oil shows in the Miocene volcanic tuffs, as well as the Tangaroa Sandstone. After testing Kora 1 was plugged and Kora 1A was side tracked from a depth of $1754 \mathrm{~m}$ to a depth of $1914 \mathrm{~m}$. The primary target of Kora 1A was the Miocene volcanism (ARCO Petroleum NZ Inc., 1988a).

The wells encountered a thick sequence of young unconsolidated sediments, with an age range from recent to Pliocene. Lying below, the thick sequence of sediments is a 900-m-thick column of Miocene volcanics tuffs (ARCO Petroleum NZ Inc., 1988a). The volcanic deposits lie on top of an unconformity with Oligocene deep water clays and siltstones. Underneath the volcanic edifice, the Oligocene limestones provide a trap and seal for the Tangaroa sandstones of the Kaiata formation (ARCO Petroleum, 1988a; OMV New Zealand Ltd, 2011).

Kora-1 showed significant indication of hydrocarbons both situated in the volcanic tuffs, and the Tangaroa sandstone. The Miocene volcanic section was tested to flow at 1168 barrels of oil per day (BOPD) at 1785 to 1810 m depth (ARCO Petroleum NZ Inc., 1988a). Kora 1A was then side-tracked to further test the volcanics hydrocarbon 
potential. A long term flow rate test was conducted with 668 BOPD sustained (ARCO Petroleum NZ Inc., 1988a).

The well bore was abandoned on March the $17^{\text {th }} 1988$.

Kora 2 was spudded on the $3^{\text {rd }}$ of June 1988, and is ARCO petroleum second exploration well inside the Kora structure (ARCO Petroleum, 1988b). The well is located $80 \mathrm{~km}$ northwest of New Plymouth in the Tasman Sea. The main target for this well was the Miocene volcanic tuffs. The well encountered two main units, the loosely consolidated thick Pliocene upper sediments and the underlying Miocene volcanics (ARCO Petroleum, 1988b). Oil was seen in the top few meters of the volcanics, but had very low oil saturations as shown by core analysis. Oil was deemed to be only residual. Kora 2 was abandoned on the $2^{\text {nd }}$ of July 1988.

Kora 3 was the third well to be drilled by ARCO petroleum, located on the Kora structure (ARCO Petroleum NZ Inc., 1988c). The well was drilled to a depth of 1934 $m$ and encountered the same two stratigraphic units as the other wells, including the main target of the Miocene volcanic tuffs. Kora 3 showed poor porosity and permeability when compared to Kora 1 and $1 \mathrm{~A}$, even though spatially they are very close. Porosity ranged from $0-9 \%$ in the upper meters of the volcanic unit. Oil shows were located within the fractured porosity, but when stem tested the well only produced 75 bbls of formation water. Kora 3 was subsequently plugged and abandoned on the $3^{\text {rd }}$ of August 1988 (ARCO Petroleum NZ Inc., 1988c).

Kora 4 was the fourth exploration well drilled by ARCO petroleum on the Kora structure. The well was spudded on the $4^{\text {th }}$ of August 1988 (ARCO Petroleum NZ Inc., 1985). Kora 4 had two main targets, one to test the Miocene volcanic tuffs in an upthrown block, and two to retest the Tangaroa Sandstone below the volcanic structure. Kora 4 is located $80 \mathrm{~km}$ north northwest of New Plymouth, and $4.5 \mathrm{~km}$ west southwest of the Kora 1 well. This well is located in an up-thrown block of the volcanics that had not been tested previously (ARCO Petroleum NZ Inc., 1985).

Kora 4 intersects the same units as seen in Kora 1, starting with the $1.5 \mathrm{Km}$ of Giant Forsets Formation, consisting of loosely-consolidated Pliocene sediments (ARCO Petroleum NZ Inc., 1985). The Giant Forsets Formation is mainly made up of clay 
sediments with some limestone and sandstone traces. Underlying this is $200 \mathrm{~m}$ of volcanic pyroclastic rock (average $5-10 \mathrm{~cm}$ in size) and reworked volcanic tuffs (Bergman, et al., 1992). The volcanic sediments are believed to have been deposited in the marine environment. The bottom of the sequence is mixed volcanic and pelagic sediments with the volcanic rocks being altered into clay. Underlying this is $800 \mathrm{~m}$ of clay sediments with minor sandstone beds making up the Mahoenui formation. This overlies the Tangaroa Formation which is interpreted to be of submarine fan origin. The Tanagroa Sandstone is a massive sandstone (ARCO Petroleum NZ Inc., 1985).

Kora 4 was drilled down to $3500 \mathrm{~m}$ and intersected both the main targets of the upthrown volcanic tuffs and Tangaroa Sandstone. A lack of porosity is seen in the volcanics, however, $22 \%$ porosity is found in the Tangaroa Sandstone with indigenous oil shows (ARCO Petroleum NZ Inc., 1985). Kora 4 was plugged and abandoned on the $10^{\text {th }}$ of September 1988. 


\section{Chapter 3}

\section{Methodology}

\section{$\underline{3.1 \text { Introduction }}$}

The application of using seismic waves to image the Earth first occurred in 1910 when Mohorovičić created the first model of the earth based upon reflecting seismic waves, produced by earthquakes (Mohorovičić, 1910). Since this point, seismic imaging has had an increasing role to play in understanding the geology beneath the surface.

Seismic interpretation is the process of extracting geological information from seismic refraction or reflection data. This can be done in a number of ways, from using reflection travel times, to using more complex methods such as amplitude and other attribute analysis. Data for this thesis mainly concentrates on traditional reflection mapping, as well as the use of a coherency cube. Seismic interpretation forms the foundation for this thesis, and the following conclusions and results all stem from the raw geological data provided by seismic interpretation within the Kora 3D.

This section is an overview of the interpretation steps and other methodology taken for this thesis. This includes the detailed mapping of the volcanic edifice and sediment column, the implementation of the coherency cube, and the use of wells.

\subsection{Set up}

Seismic interpretation requires i) seismic data, and ii) an interpretation program to view, manipulate, and interpret the data. To visualize the seismic data Paradigm SeisEarth version 12 was used in this study, with a computer supplied by GNS Science. Paradigm SeisEarth is a widely used seismic interpretation software, used both in 
industry and research. SeisEarth is part of a larger Paradigm package, including programs able to model and image multiple aspects of the petroleum geological system. All visualisation of the well markers and biostratigraphic ages can also be done within SeisEarth. Databases can also be managed within Paradigm, with its own database tools such as 'Interpretation Manager'.

Trap Tester is another seismic interpretation programme used in this study. Trap Tester is produced by Badleys Earth Sciences for the petroleum industry, and mainly focuses on the analysis of fault planes and stresses at regional to borehole levels. In this study, it was only used to analyse slip on fault surfaces over time, as well as strain within the seismic reflection volume. Data was imported into Trap Tester from Paradigm.

Seismic and well data older than 5 years old is available from the NZP\&M GOLD database, provided by the New Zealand Ministry of Economic Development. The New Zealand government has a regulation that within 5 years of new data being acquired by an exploring party, it must be released to the public (New Zealand Government,. 1991). All the data used in this thesis were publicly available.

The seismic and all well data were loaded into Paradigm from GNS sciences' local server, which can be accessed with a local internet connection. GNS Science have also supplied all petroleum industry data for this study directly from NZP\&M.

The Kora 3D and surrounding 2D seismic lines used in this study are outlined in Appendix F. The Kora 3D was acquired between December 2005 and 2006. Kora 3D reflection survey became publicly available in 2010 (OMV New Zealand Ltd, 2011). The Kora 3D seismic data package includes a pre-stack time migration, pre-stack depth migration, as well as AVO, and seismic coherency cubes. Seismic processing was completed by VERITAS DGC Australia on behalf of OMV limited NZ (OMV New Zealand Ltd, 2011). Seismic importing was done by Chris Town at GNS, following paradigm instructions and byte location provided by NZP\&M.

2D seismic lines used in this study come from a wide range of vintages. Past 2D seismic lines were acquired by ARCO petroleum, Shell BP \& Todd Oil Services, and TGS-NOPEC. A full list of 2D seismic surveys can be found in Appendix F. 
Four wells form the basis of the work done in this study; Kora $1-1 \mathrm{~A}$, Kora 2, Kora 3, and Kora 4. Ariki-1 and Tangaroa-1 were also used, but only for the purpose of tying in seismic horizons and dating the volcanic activity. All of these listed wells are for oil and gas purposes. Kora $1,-1 A, 2$, and 3 are located on the centre in the 3D seismic volume, on top on the volcanic edifice as delineated by a magnetic anomaly (ARCO Petroleum, 1988). Kora 4 is located to the South West of the other wells and penetrated through an up thrown block of the volcanic edifice. The wells are relatively bunched together, therefore, some well tying outside of the 3D seismic volume is necessary to validate seismic horizon picks. Ariki 1 is located $25 \mathrm{~km}$ north west of Kora 1 and provides a good quality well log. Tangarao-1 is located to the southeast and also provides a suitable well to seismic tie to.

The wells used in this study provide lithological as well as depositional data, this information can be used to influence the picks of formation tops, the basis for seismic horizon mapping. Well correlations were also crucial in this study, with importance given to changing of thickness, change in depositional setting, and pinch outs between the wells. This becomes ever more important when dealing with volcanic deposits as the seismic attenuation is high, impairing the ability to map seismic horizons underneath the volcanic edifice. Seismic well ties can be found in Appendix D.

As well as providing vital lithological and depositional data, the wells also come with check shot data. This datum allows the user to convert TWTT measured in seconds (or milliseconds) into a depth measured in $\mathrm{m}$ or $\mathrm{km}$ (Appendix B). Check shot datum also allows for geophysical logs created during drilling to be matched with seismic reflections correctly. However, the wells are of old age and some check shot datum was been deemed unreliable, mainly for Kora 2 and 4, but was still used due to a lack of other data in the area (OMV New Zealand Ltd, 2011).

Biostratigraphy is also utilised in this study. Biostratigraphy was used to gather ages on mapped horizons and also as a correlation method between wells. Well completion reports, as well as correlation studies completed by GNS Science provided the biostratigraphic information for this study (Hayward, 1985; 1986; Waghorn, et al., 1996; GNS Science, 2002; Hansen \& Camp, 2004; Strong, 2006). 
Biostratigraphic ages for the used wells were loaded into Paradigm. as well as well formation tops. Biostratigraphic stages and formation tops were shown on seismic reflection data. New Zealand biostratigraphic stages were used.

Regionally mapped horizons completed by multiple members of the GNS Science Petroleum division were used by this study to give an overall foundation. The horizons regionally mapped include horizons P50, P60, N10, N30, N40, N60, and N80, however, only 2 were present within the Kora 3D seismic volume itself; N30 and N60. The nomenclature used to name the horizons originated from the early GNS Science attempts to conform seismic interpretation done by multiple parties, and then updated for the use of the Taranaki 4D project (Strogen \& King, 2014). The regional interpretation done on 2D lines with the study area provided vital seismic ties to base an interpretation on.

\subsection{Seismic interpretation}

This study uses a computer and Paradigm licence provided by GNS Science. The study also follows typical seismic interpretation procedure. A high emphasis throughout the methodology was put on capturing fault planes as accurately as possible within seismic resolution.

Methodology for seismic interpretation and analysis for this study is as follows:

1) WestNZ project created by the Petroleum division at GNS Science was loaded into Paradigm. The project included access to all 3D seismic surveys and 2D seismic lines on the West coast of the North Island. All 2D lines used for this survey were quality checked, as well as determining miss ties to one another.

2) Kora 3D seismic reflection survey was loaded into the systems random access memory (RAM), this included both the amplitude and coherency volumes. Quality checking was done on both Kora volumes, mainly assessing miss ties with the intersecting 2D seismic lines.

3) All Kora wells (Kora 1, 1A, 2, 3, and 4) as well as Ariki-1 and Tangaroa-1 were loaded into the project with accompanying biostratigraphic and 
lithostratigraphic markers. Markers were quality checked against well sheets, other wells, and the already mapped seismic horizons. Check shot data and log data was also loaded in.

4) Fault interpretation on inlines was the first personal interpretation to occur in this study. Fault picking was mainly done using the coherency view, and only faults with visible offset were picked. Inline spacing of 10 was used giving the fault picks resolution of $125 \mathrm{~m}$. Inlines were used as many of the fault strikes were in perpendicular orientations to the inlines. Also inlines provide the most reliable seismic accuracy in this survey. Up to 65 faults were picked throughout the Kora 3D seismic survey.

5) Some fault orientations needed fault picks to be done on cross lines due to their strike. This was done on 10 line spacing or $125 \mathrm{~m}$. This was especially essential as faults got closer to the volcanic edifice and orientations of faults seemed to change.

6) N10 was the first horizon to be picked in this study, personal picking follows on from already interpreted 2D intersecting lines. N10 is $21 \mathrm{Ma}$ and was deposited in the early Miocene, New Zealand biostratigraphic stage of Otaian (Po). The seismic response can be seen by a relatively bright reflector underneath the volcanic edifice.

7) N30 was the second horizon to be picked in this study. This horizon wraps around the volcanic edifice and is a good marker for many fault offsets. The age of the horizon is $16 \mathrm{Ma}$, located chronostratigraphic at the boundary between the Early and Middle Miocene. N30 has the New Zealand biostratigraphic stage of Lillburnian-Clifdenian (Sc-SI).

8) N40 is $12 \mathrm{Ma}$ and lies in the boundary between the Late and Middle Miocene. This horizon was the third to be picked. This horizon along with others fills the upper section of the seismic survey.

9) N60 was the fourth horizon to be picked in this study. The horizon is $6 \mathrm{Ma}$ and is at the base of the Pliocene. The horizon has the New Zealand biostratigraphic stage of Kapitean (Tk).

10) $\mathrm{N} 80$ is the youngest and the fifth horizon mapped in this project. The horizon only has four fault offsets throughout the Kora 3D seismic survey. The horizon 
has the age of 2-3 Ma, and is located on the boundary between the Pleistocene and the Pliocene. Its New Zealand biostratigraphic stage is Nukumaruian (Wn).

11) P60 was the sixth horizon to be picked in the seismic volume. This horizon passes underneath the volcanic edifice and can be difficult to map. The horizon has an age of $26 \mathrm{Ma}$, and is marked by a strong reflector that marks the limestone change in lithology.

12) P50 is the oldest horizon mapped in this study, and was also the last horizon to be mapped. Underneath this horizon reflector, seismic reflectors become hard to distinguish and so do fault offsets. The age of this horizon is $35 \mathrm{Ma}$, and is dated at the base of the Oligocene. The horizon has the New Zealand biostratigraphic stage of Whaingaroan (Elwh).

13) Volcanic deposits and the volcanic cone were next to be picked. Volcanic deposits can be easily mapped in seismic reflection data as they can be distinguished by their seismic characteristics. Volcanic deposits have a high amplitude upper reflector, followed by chaotic disrupted low amplitude reflectors beneath. Deposits surrounded the volcanic edifice and also stretched out to the east.

14) Fault picks originally were 'sticks', only correlated to one other by name. Paradigm offers a tool to create a polygon between fault picks, allowing the creation of fault planes in 3D. All fault picks were used to create associated fault planes. Some fault planes were not considered to be 'geologically' correct, therefore, quality checking and re-evaluation of previous fault picks was the next step. Basis for quality checking and the determination of "geologically" correct fault planes was determined by previous knowledge and experience of visualising and studying fault planes in the past. If a fault plane visualised on the computer did not look like it had a natural origin, then this would be re-evaluated.

15) A mass transport feature was recognised within the Kora survey, and was mapped. This was done for examination at a later period. The mass transport feature seemed to be bound by a vertical slip surface, and also wrapped 
around the volcano. Mapping was done on the top and base of the structure at 50 line spacing $(625 \mathrm{~m})$ and only on inlines.

16) High amplitude seismic responses were seen above the volcanic edifice. The polygon feature supplied by Paradigm was used to map the structure of the high amplitude features. The structures were mapped from $680 \mathrm{~ms}$ deep to 200 ms deep, with 50 ms intervals.

17) More detailed mapping of the Kora volcanic cone was done. This was mainly done so a better geomorphic picture of the volcanic cone could be seen. This also had the added benefit of better capturing fault offsets near the cone. Multiple line spacings were used. On top of the cone, mapping was done every fourth line $(50 \mathrm{~m})$.

18) Seismic horizons to better constrain the age of the volcanic deposits were mapped at this point in the study. A seismic horizon was picked at the first occurrence of volcanic deposits, on-lapping the volcanic cone, and one below the deposits that passes through the volcanic edifice largely unchanged. These horizons were dated using well ties provided by Ariki-1 and Tangaroa1.

19) The project was then moved onto Trap Tester with a licence supplied by GNS Science. Movement of the project involved exporting interpretations from Paradigm and importing the interpretation into Trap Tester. This was done with considerable help from another Master's student Hamish Cameron.

20) In this study, Trap Tester was used to produce fault growth curves. This involves exporting the data from Trap Tester and loading it into Excel. Trap Tester has the ability to create the curves and many other fault related attributes. Once loaded into Excel, fault growth history graphs were created for each fault. Fault growth history curves involve using cumulative offset for each mapped horizon graphed over time. This was vital in this study and allowed the analysis of fault timing.

21) Maps were created in Paradigm to allow for visualisation of interpretation.

\section{$\underline{3.4 \text { Horizon picks to grids }}$}


Creating grids is a good way to visualise geological interpretation data on a seismic interpretation program such as Paradigm.

Methodology for creating grids for this study was as follows;

1. Fault outlines were first created in Paradigm. This could be done including fault heave or without. The process of creating fault outlines allows the grid process not to try and grid over faults, it also provides greater visual appeal. Outlines without heave will produce a line along the faults trace, while outlines with heave will create a polygon with the thickness relating to the heave along the fault. In this study, outlines with heave were used.

2. A variety of methods and algorithms can be employed to create a grid. This can range from the algorithm creating the grid, to the one used to smooth the interpretation of the grid. In this study all of the grids were created using the included minimum curvature algorithm, with a LOWESS filter. Then the grids were smoothed 2 times using a sampling window of 10 ms TWTT.

3. Quality checking the grids was the third step. Many first pass grids can be produced with unrealistic interpretations. Finding unrealistic interpretations within the interpretation is the next step. Changes can then be made accordingly.

4. Iterations of the grid making process were then completed. The result is a grid that matches the interpretation and that is completely geologically sound.

Created Grids for horizons N80, N60, N40, N30, and N10 are located in Appendix E.

\section{$\underline{3.5 \text { Well ties }}$}

Well ties were used in this study to correlate mapped horizons within the Kora 3D to biostratigraphic markers on wells outside the volume. The wells used to perform the stratigraphic ties include Kora-1A inside the survey and Ariki-1 and Tangaroa-1 outside the 3D survey. Two 2D seismic lines were used to tie between the wells Kora- 
1 and Ariki-1, and separately Kora-1 and Tangaroa-1 (Fig. 3.1). Seismic line dtb01-032847 was used between Kora-1 and Ariki-1, and seismic line 81sy-12-2174 was used between Kora-1 and Tangaroa-1. Biostratigraphic stages identified in the well were used to date the horizons mapped within the Kora 3D. Appendix D shows the seismic well ties for the Ariki-1 well and Tangaroa-1 wells respectively.

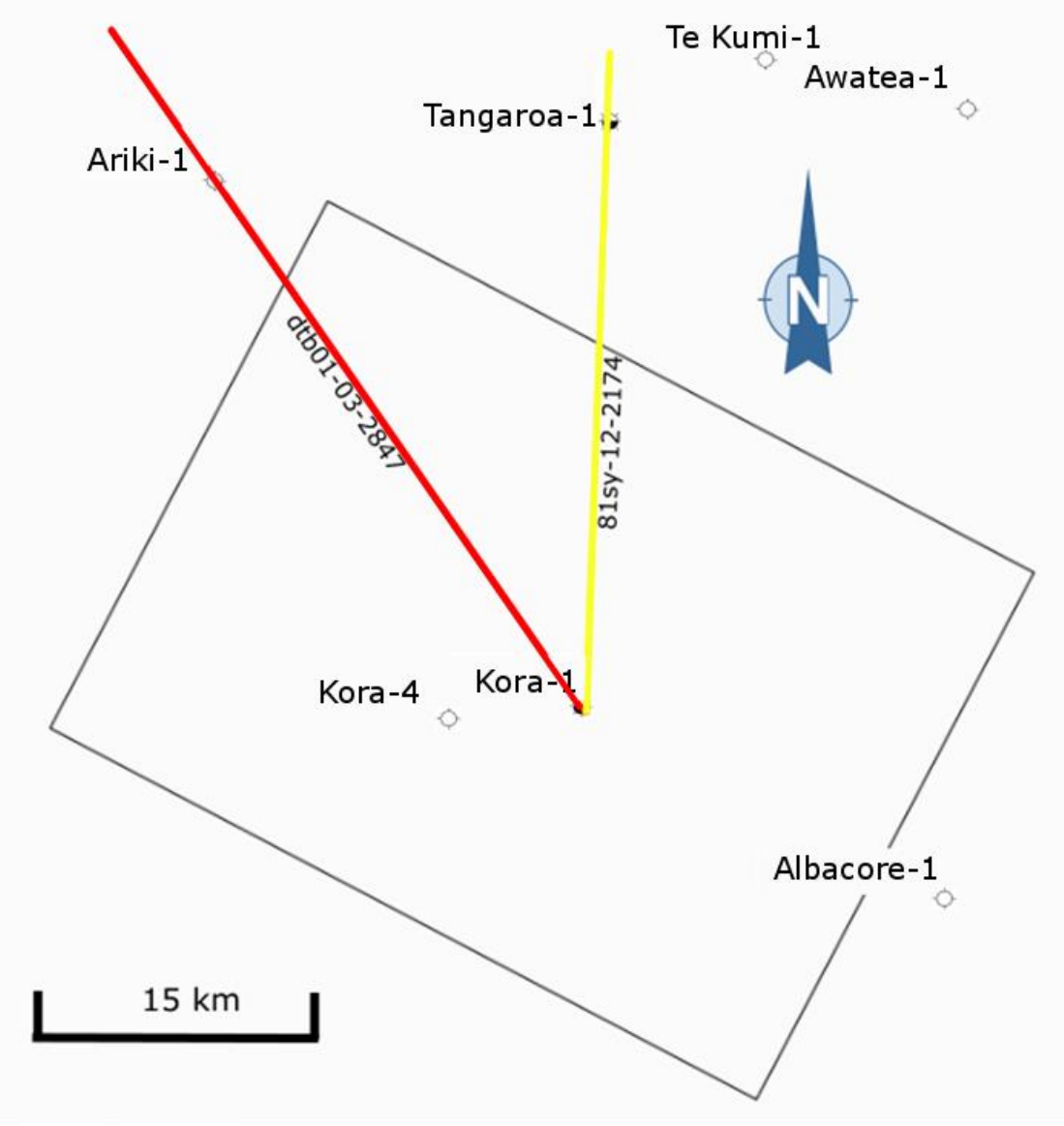

Figure 3.1. Well tie locations in map view

\section{$\underline{3.6 \text { Strain profiles }}$}

Strain profiles were created and used in this study. Strain profiles were created using the Trap Tester software created by Badleys Earth Science. Strain profiles were created using mapped faults and mapped displacements along the fault planes. It is 
worth noting that seismic interpretation has to be done in Trap Tester or imported, otherwise strain profiles cannot be created.

Calculation of strain is done along parallel lines. The line parameters can be changed. The changeable parameters involve the resolution of the profiles (how many calculation lines are done per survey), and the orientation of the lines.

In this study the orientation of the strain survey is parallel to the inlines in the survey (Fig. 3.2). This makes the calculated strain roughly normal to the strikes of the majority of faults. This will give the best approximation of true displacement, and therefore strain within the survey.

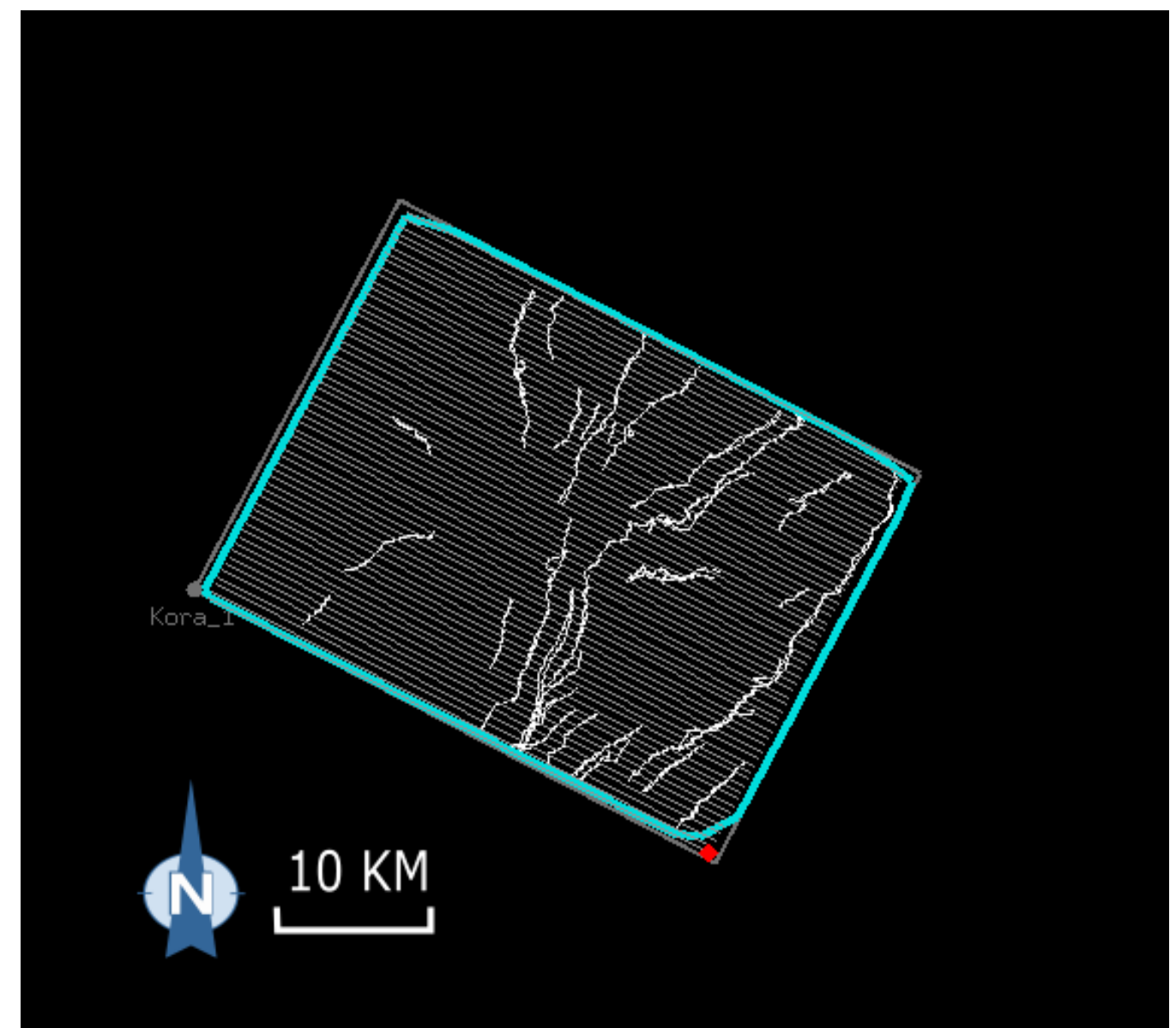

Figure 3.2. Map view of strain profile calculation grid. White lines depict the lines that strain is calculated along Red dot shows the starting location of strain calculations. The calculation lines are orientated as shown due to the strikes of the faults. When strain is measured perpendicular to strike of a fault a true strain is calculated.

Strain was calculated for each horizon, giving strain profiles for each time interval mapped. All faults mapped in this study were used to created strain profiles. Strain profiles results are displayed in chapter 4.13.

Strain profiles were produced following the steps below; 
1) Seismic interpretation was imported from Paradigm SeisEarth into Trap Tester.

2) Seismic interpretation was then checked over and quality checked. This included some re-picking of horizons up to faults, and re-picking of fault tips.

3) Strain profile parameters were then input.

4) The profiles were then created.

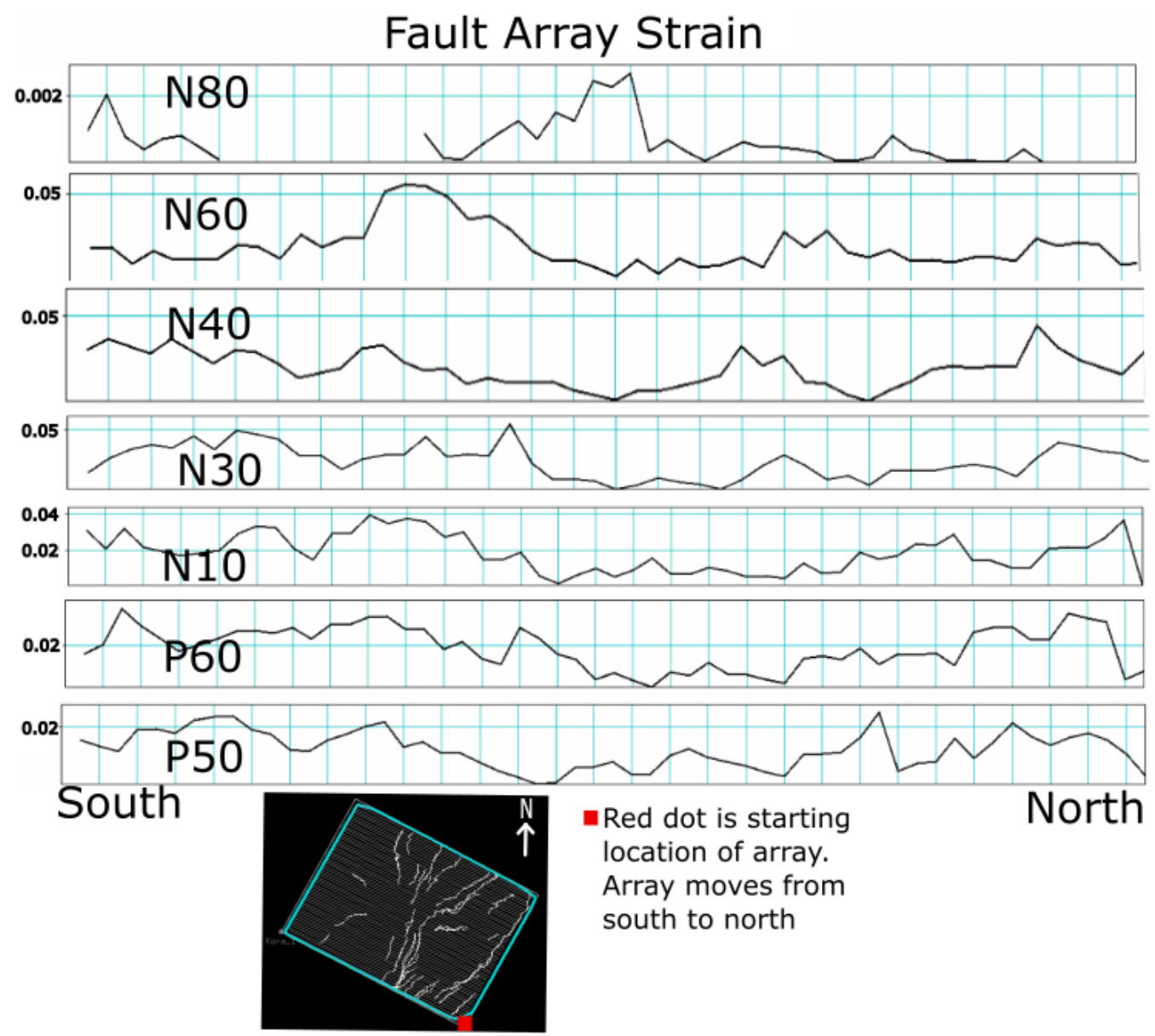

Figure 3.3. Map view of strain profile calculation grid as well as strain profiles for all mapped horizons. White lines depict the lines that strain is calculated along. Red dot shows the starting location of strain calculations.

\section{Chapter 4}

\section{Faults in the Kora 3D}




\subsection{Introduction}

Faults are widely observed in the Taranaki Basin (King \& Thrasher, 1996; Giba, et al., 2010; Reilly, et al., 2015). The present study area is within the Northern Graben, which is dominated by late Cenozoic normal faults (King \& Thrasher, 1996; Giba, et al., 2010). In this chapter, the faults mapped within the Kora 3D seismic survey located within the northern graben are identified, described, and analysed. Faults within this study area can provide a detailed tectonic history of the Northern Taranaki Basin during the late Miocene and younger time intervals. Two main types of faults were distinguished within the Kora 3D; radial volcanic faults and tectonic faults. In addition to these two fault types, a mass movement (gravitational) fault has been identified, and will be discussed.

The layout of this chapter is as follows: i) each fault type is defined in terms of strike, displacement, and locations; ii) the faults are qualitatively analysed; and iii) the processes responsible for the formation of the faults are discussed. 


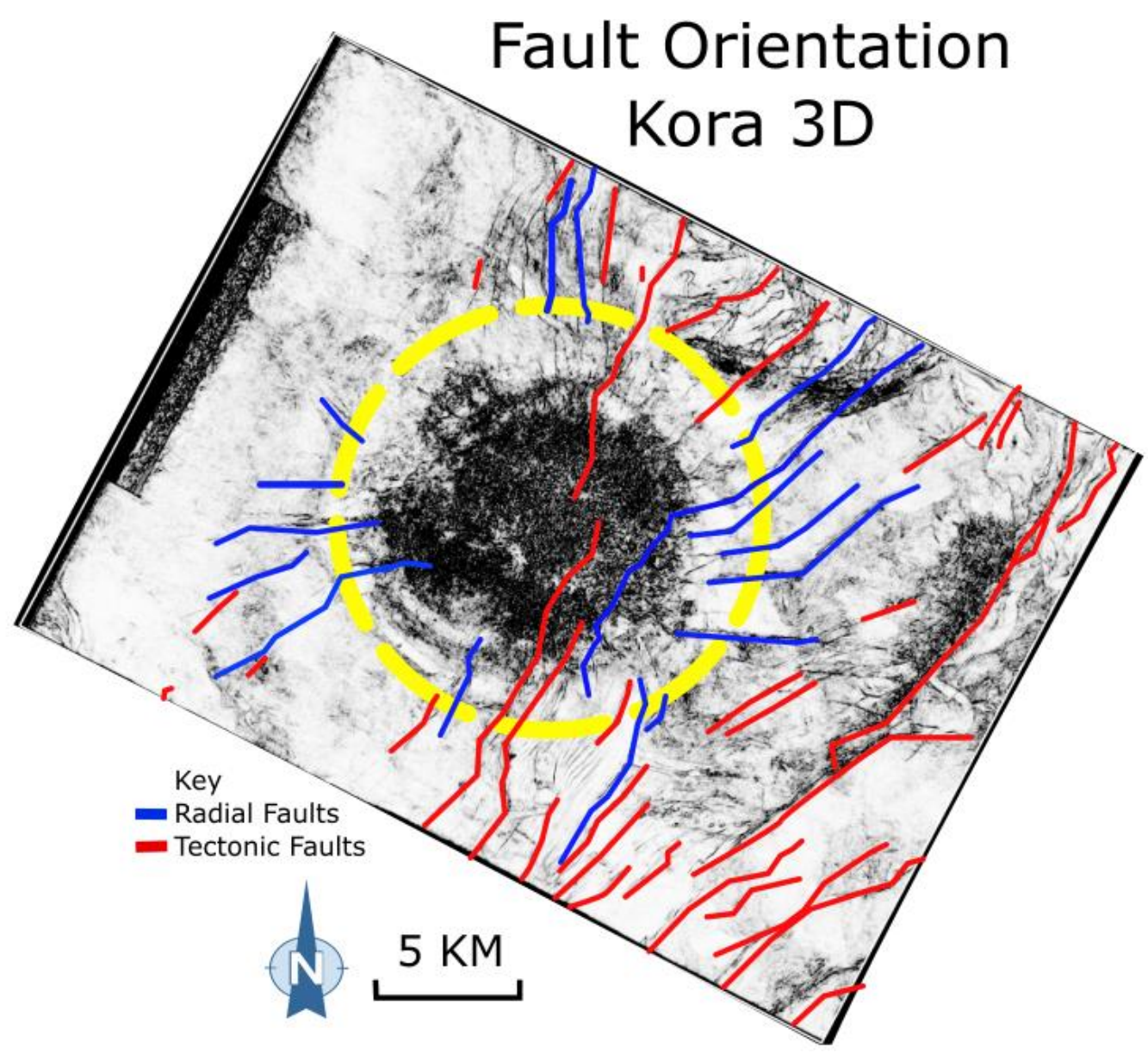

Figure 4.1. Map view of the distribution and orientation of normal faults within the Kora 3D Seismic Survey. Coloured fault traces represent the classification of faults. Yellow circle represents a radius $\sim 10 \mathrm{~km}$ from primary vent. Fault traces derived from a time slice at 2000ms TWTT. Coherency time slice background is from 2000ms TWTT.

\subsection{Radial faults}

Radial faults are formed proximal to the Kora volcanic edifice $(<10 \mathrm{~km}$ from the primary vent) from which they radiate from (see blue faults on Fig. 4.1). Radial faults in this study are defined as faults that start within the $10 \mathrm{~km}$ radius of the volcanic vent (yellow circle in Fig. 4.1), and do not have a strike of N-S or NE-SW representing the tectonic regime. The average strike of the faults ranges through $360^{\circ}$ with individual faults varying in strike by up to $40^{\circ}$. The radial faults typically have small displacements $(<70 \mathrm{~ms})$ and mappable lengths of $5-10 \mathrm{~km}$. Minorcensoring of fault lengths occurs when measuring radial faults. 


\section{$\underline{4.2 \text { Radial fault strike }}$}

Radial faults are interpreted to form within $10 \mathrm{~km}$ of the Kora Volcanic edifice, and are locally accompanied by tectonic faults. To remove subjectivity associated with the selection of radial faults I have measured the strike of all faults $(n=20)$ within a radius of $10 \mathrm{~km}$ from the top of the volcanic cone (Fig 4.2). In each case the average faults strike has been determined using Trap Tester software.

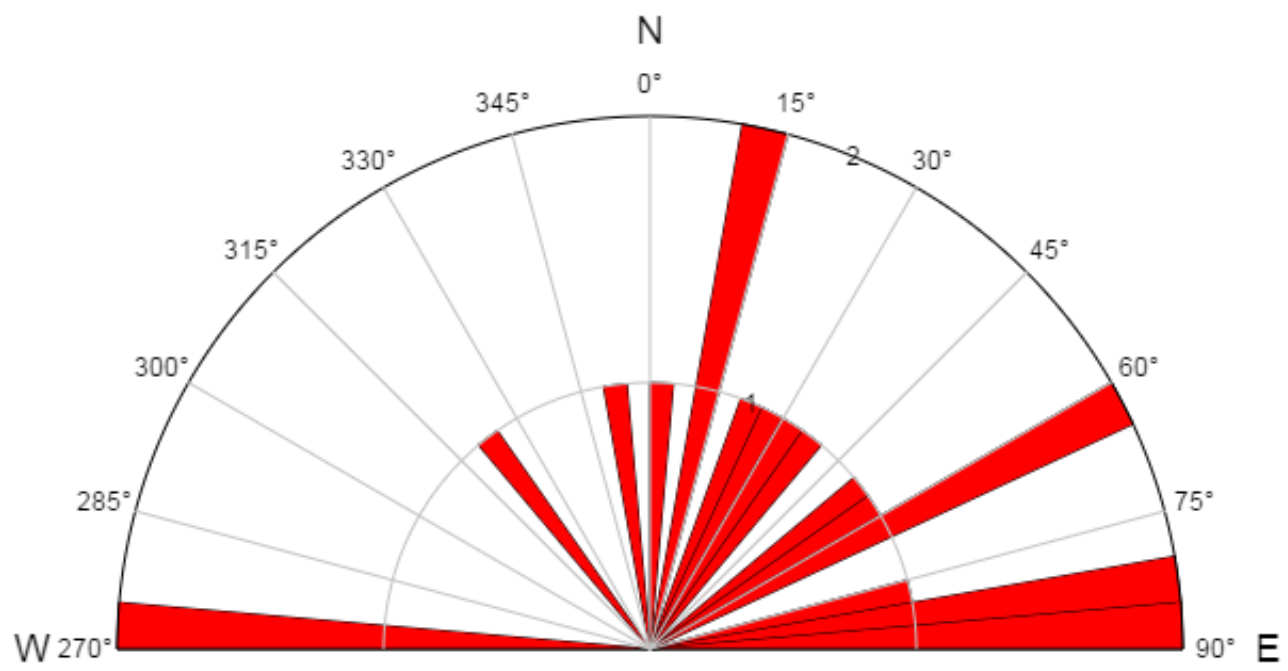

Figure 4.2. Rose diagram showing the strikes of mapped radial faults (blue faults as determined by fig 4.1) within the Kora 3D Seismic Survey. The number of faults sampled is 20. Diagram created using Young Technology Inc software. (http://www.yongtechnology.com/yong-lab/online-rose-diagram)

The fault strikes presented in figure 4.2 do not appear to show a clear preferred orientation. Despite the fact that Kora 3D sits within a NE-SW trending sift system, the rift system is not strongly represented in the rose diagram. There is however, an absence of faults striking at $275-320^{\circ}$, and orientated normal to the rift system. This is similar to other findings around New Zealand and the world, where fault strikes vary around a volcanic cone even though the volcanic edifice is located within a rifting system (Campbell, et al., 2007).

A number of the faults mapped shown in figure. 4.1 change strike with increasing distance from the volcanic edifice. Close to the volcanic cone $(<10 \mathrm{~km}$ from the primary vent) fault strikes are variable, however, with increasing distance from the cone the strikes tend to become increasingly north-easterly. These changes in fault strike may reflect changes in the dominant primary stress field (Nakamura, 1977). 
Close to the cone stresses are mainly controlled by volcanic processes (e.g. vertical movement of magmas, magma chamber formation, and locally high thermal anomaly), which produce radial tension $\left(\sigma_{3}=\sigma_{2}\right)$. Approximately with increasing distance from the cone the regional stress field becomes progressively more dominant. In the Northern Graben, late Miocene normal faults are consistent with a NW-SE trending $\sigma_{3}$ and a NE-SW $\sigma_{2}$ (Giba, et al., 2010).

Nakamura, 1977, showed the tranistion zone between locally created stresses and regional tectonic stresses using volcainic dykes. Just as seen in the Kora 3D radial faults, the dykes presented by Nakamura change strike as they leave the area under the local volcanic stress.

\subsection{Length and offsets of radial faults}

Radial faults have small lengths and low displacements when compared to the tectonic faults within the 3D survey area. The longest radial fault within the survey is $15.6 \mathrm{Km}$ long, while the shortest has a length of $2.8 \mathrm{Km}$. The majority of faults lie between the lengths of 5 and $10 \mathrm{Km}$. Only 3 out of 20 radial faults have censored lengths.

Maximum displacements of radial faults range from 5 to $90 \mathrm{~ms}$, with the majority between 20-70 ms. 


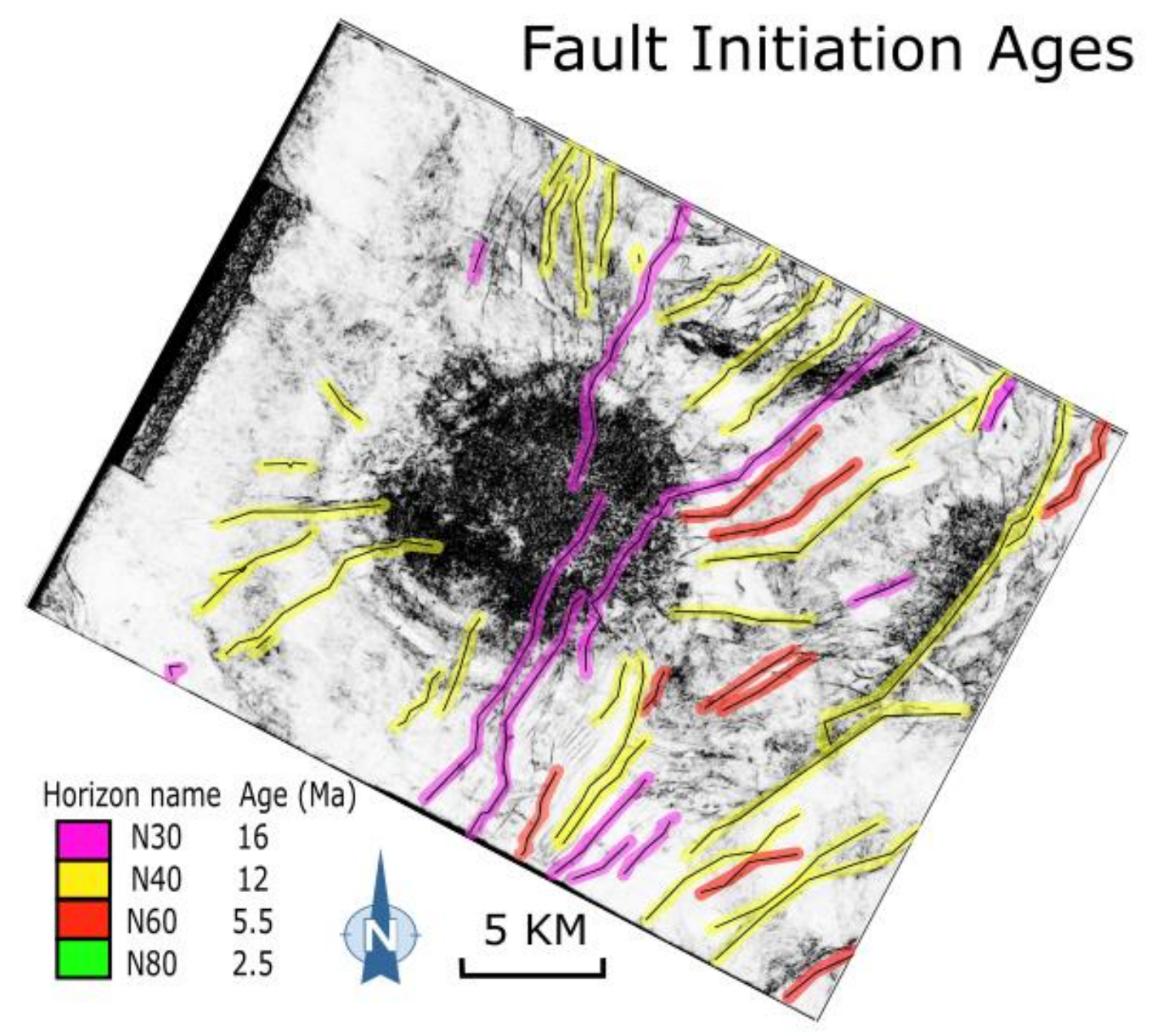

Figure 4.3. Ages of initiation for normal faults within the Kora 3D. Fault trace colours represent the initiation age of the fault. Fault traces and coherency time slice from 2000ms TWTT.

In areas of rifting where sedimentation rates have exceeded displacement over a long period, syn-deformational strata on a fault can be used to determine the fault growth history of that particular fault (Childs, et al., 2003; Giba, et al., 2010; Giba, et al., 2012). The process of determining fault growth history includes sequentially back stripping by removing displacements on progressively older horizons. Back stripping allows the user to determine the displacement that accrued on a fault during deposition of stratigraphic intervals, providing a fault movement history (Childs, et al., 2003). Figure 4.4 provides some examples of growth history plots for faults within $10 \mathrm{~km}$ of the primary vent within the Kora 3D. Inflection points on the growth curves associated with an increase in gradient with decreasing age, mark the initiation of faulting (Childs, et al., 2003; Giba, et al., 2012). 
The initiation of a fault allows the observer to determine the stresses and tectonic climate that led to the formation of said fault (Childs, et al., 2003). On a larger scale, the initiation of a group of faults can be used with the same logic only with a larger certainty, and a greater scope.

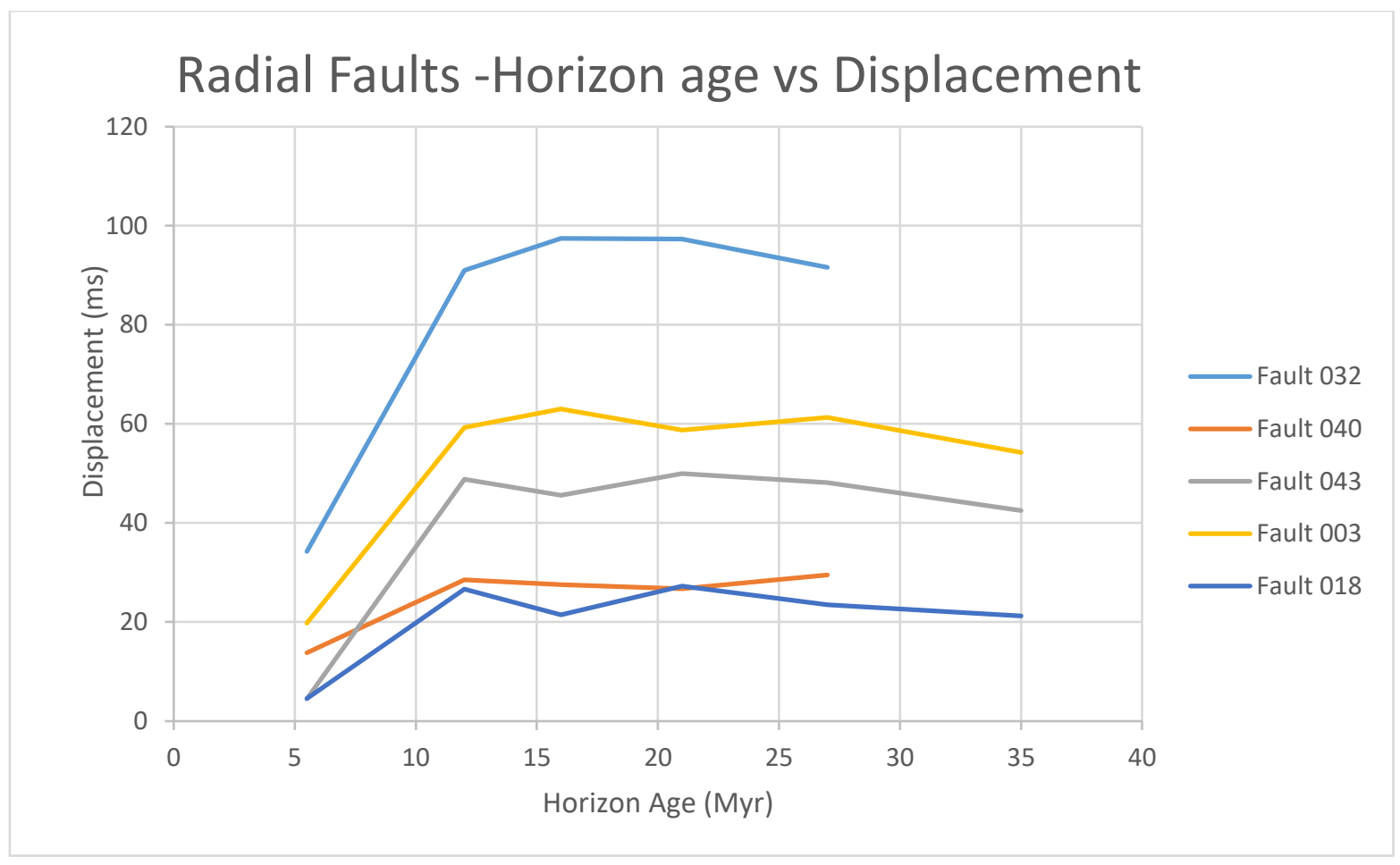

Figure 4.4. Growth profiles for five radial faults. Growth plot data was acquired through mapping of faults and horizons.

Faults 032, 040, 043, 003, and 018 all initiated at the 12 Ma horizon marker as shown by the growth history curves in figure 4.4. Fault 032 has the largest offset of all the faults, the fault also represents the largest step in growth history. Changing offsets with increasing age and depth are probably due to mapping error created by the increasing lack of resolution with depth.

A map view of the initiation ages makes it a lot clearer to see a pattern throughout the radial faults (Fig. 4.3). A majority of the radial faults initiated around $12 \mathrm{Ma}$, and only a few faults to the east are younger with initiation ages of $5.5 \mathrm{Ma}$. The majority of radial faults were initiated at $12 \mathrm{Ma}$ which is younger than the onset of intrusive volcanism in Kora (19 Ma) as recorded in the Kora-1,1A and 4 wells (Bergman, et al., 1992). 


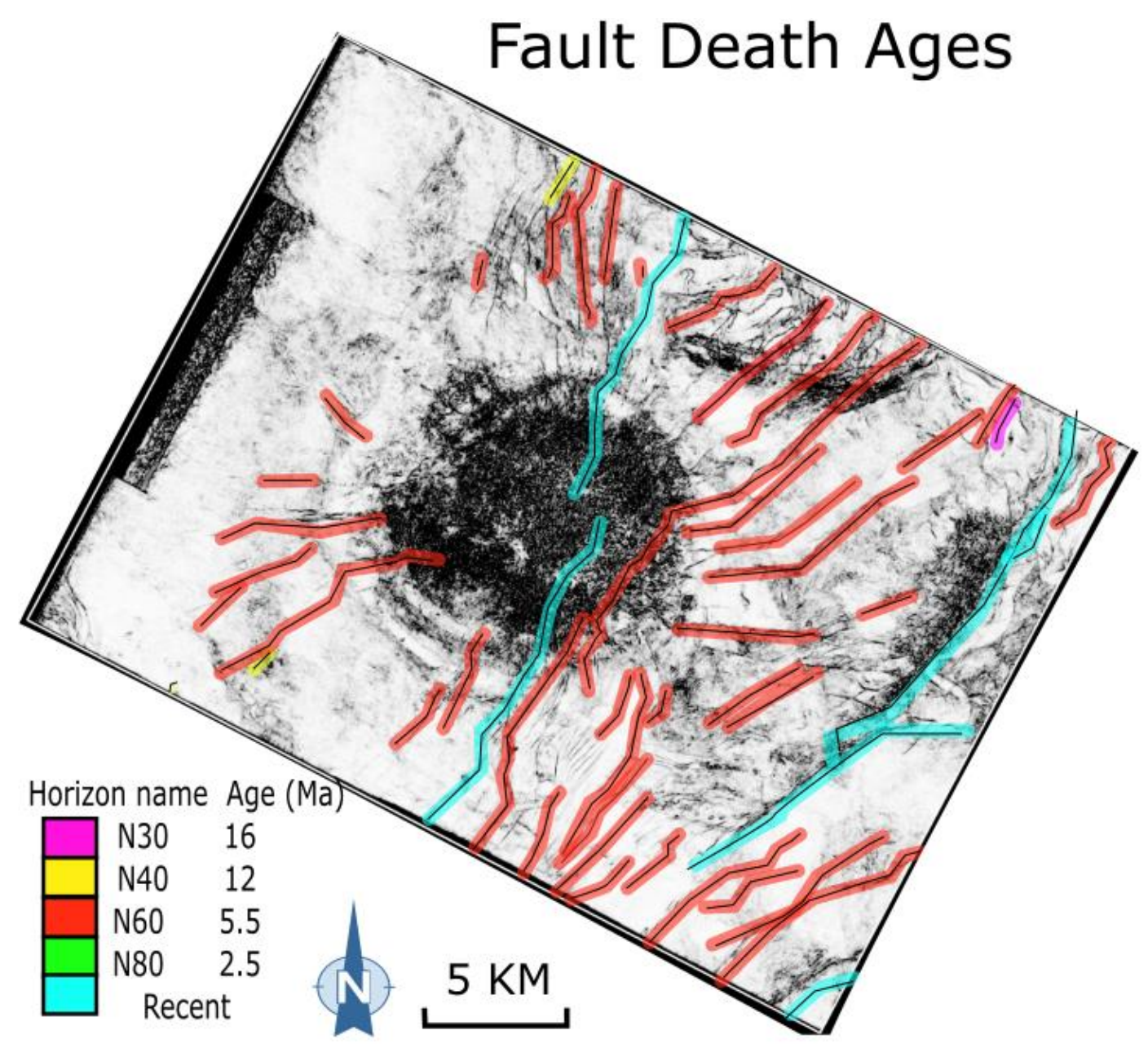

Figure 4.5. Map of fault death ages. Fault trace colours represent the death age of the fault. Fault traces and coherency time slice from $2000 \mathrm{~ms}$ TWTT

The death of a fault indicates the lack of well-orientated stress, or lack of wellorientated slip surface to cause slip along said fault surface (Jackson, 1999). Fault death indicates a change in the stress conditions, therefore, knowing the age of fault death can help us improve our understanding of the stress conditions in the past.

In this study, the age of fault death was determined by the age of the last horizon to be faulted. This is a common practice for determining fault-death ages (Giba, et al., 2010; 2013). None of the radial faults in this study have visible displacement of the seabed surface or near reflectors ( $<50 \mathrm{~ms}$ TWTT). Therefore, the radial faults have not been active geologically during the Late Quaternary to recent.

Figure 4.5 shows a map of fault death ages for the Kora 3D survey. All except three small radial faults died between the N60- N80 horizons or 5.5-2.5 Ma time interval. 
In common with the initiation age of these faults, the timing of fault death is relatively consistent.

The near-uniform timing of death of the radial faults is thought to be due to the death of Kora Volcano, and the migration of normal faulting and associated stresses (King \& Thrasher, 1996; Giba, et al., 2010). The migration of normal faulting and associated stresses is due to the clockwise rotation of the Eastern Taranaki Basin, and steeping or rollback of the subducting Pacific Plate (King \& Thrasher, 1996; Giba, et al., 2010). Both the clockwise rotation and steepening or slab rollback of the pacific plate are well-documented phenomena along the west coast of the North Island, New Zealand (Giba, et al., 2010; 2013; Seebeck, et al., 2014).

\subsection{Radial fault formation}

Stress magnitude and orientations locally within a volcanic edifice can differ from the regional tectonic stresses (Fiske \& Jackson, 1972; Nakamura, 1977). Local changes in stresses across volcanic edifices are observed worldwide (e.g. Hawaii and Iceland) and has been examined by mapping dykes in areas surrounding volcanic cones (Fiske \& Jackson, 1972; Patanè, et al., 2003).

The formation of the radial faults that surround the Kora Volcanic edifice is interpreted to be due to the local stress field created by the volcanic edifice. Two possible models to explain the formation of radial faults are considered.

The first model depicts radial faults forming due to the emplacement of intrusive volcanic material (Fig. 4.6). The second model shows extrusive volcanic material, extruded during cone building phases, that changes the local vertical stress and forms radial faults (Fig. 4.7).

Kora magmatism is thought to have commenced at $19 \mathrm{Ma}$ intrusively, followed by an extrusive interval starting from 15 Ma (Bergman, et al., 1992). During the intrusive interval, magma was emplaced under what is now the volcanic edifice. The first model is based around the fact that emplacement of volcanic material underneath a rock column creates upward bulging of the overlying strata, and the 
associated stress led to the formation of faults (Fig 4.6) (Moran, 1994; Patanè, et al., 2003). The stress created by intrusion would be local to the area of emplacement. (Nakamura, 1977; Patanè, et al., 2003).

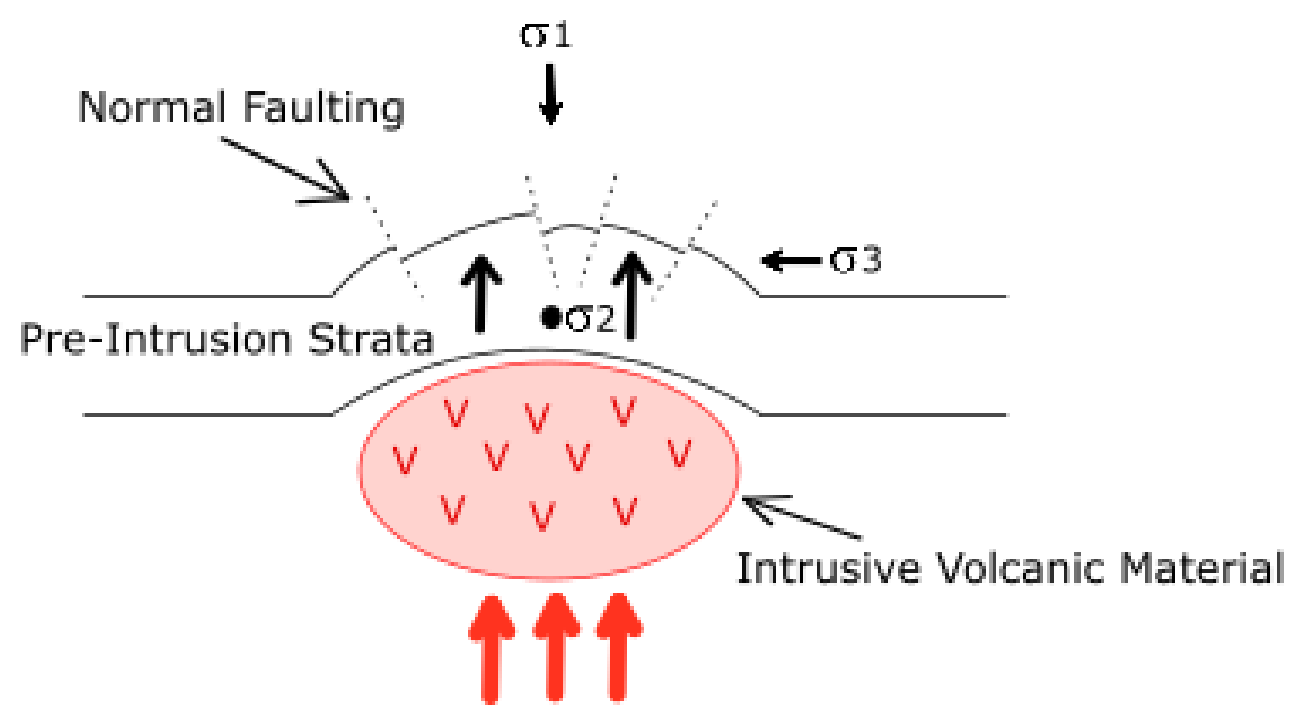

Figure 4.6. Simplified cartoon cross section for model 1. Radial faults are formed by the emplacement of intrusive volcanic material which locally uplifts and stretches the overlying strata. Red arrows show the direction of magma intrusion. Thick black arrows indicate uplift of sedimentary cover sequence. Orientations of $\sigma_{1}, \sigma_{2}$, and $\sigma_{3}$ are shown with $\sigma_{2}$ and $\sigma_{3}$ being approximately equal.

An analogy that can be used to show the emplacement model in effect would be that of an inflating air bladder beneath a thickness of sand. As the air bladder is inflated re-creating the emplacement of volcanic material, the sand above the bladder would begin to break or fault. The faults reflect extension of the sand due to circular-shaped doming.

In the second model, radial faults form in association with loading of the strata by erupted volcanic material (Fig. 4.7).

Gravitational loading created by the volcanic cone emplacement and subsequent building locally changes the stress field from the regional pattern. In the second model the volcanic cone creates a down warping or subsidence which forms the radial faults. Like the first model, model 2 would arise due to horizontal (and approximately equal) $\sigma_{2}$ and $\sigma_{3}$ with $\sigma_{1}$ being vertical. However, unlike model 1 , which would predict that volcanism and radial faulting are synchronous, model 2 could achieve radial faulting during and after the cone building. 


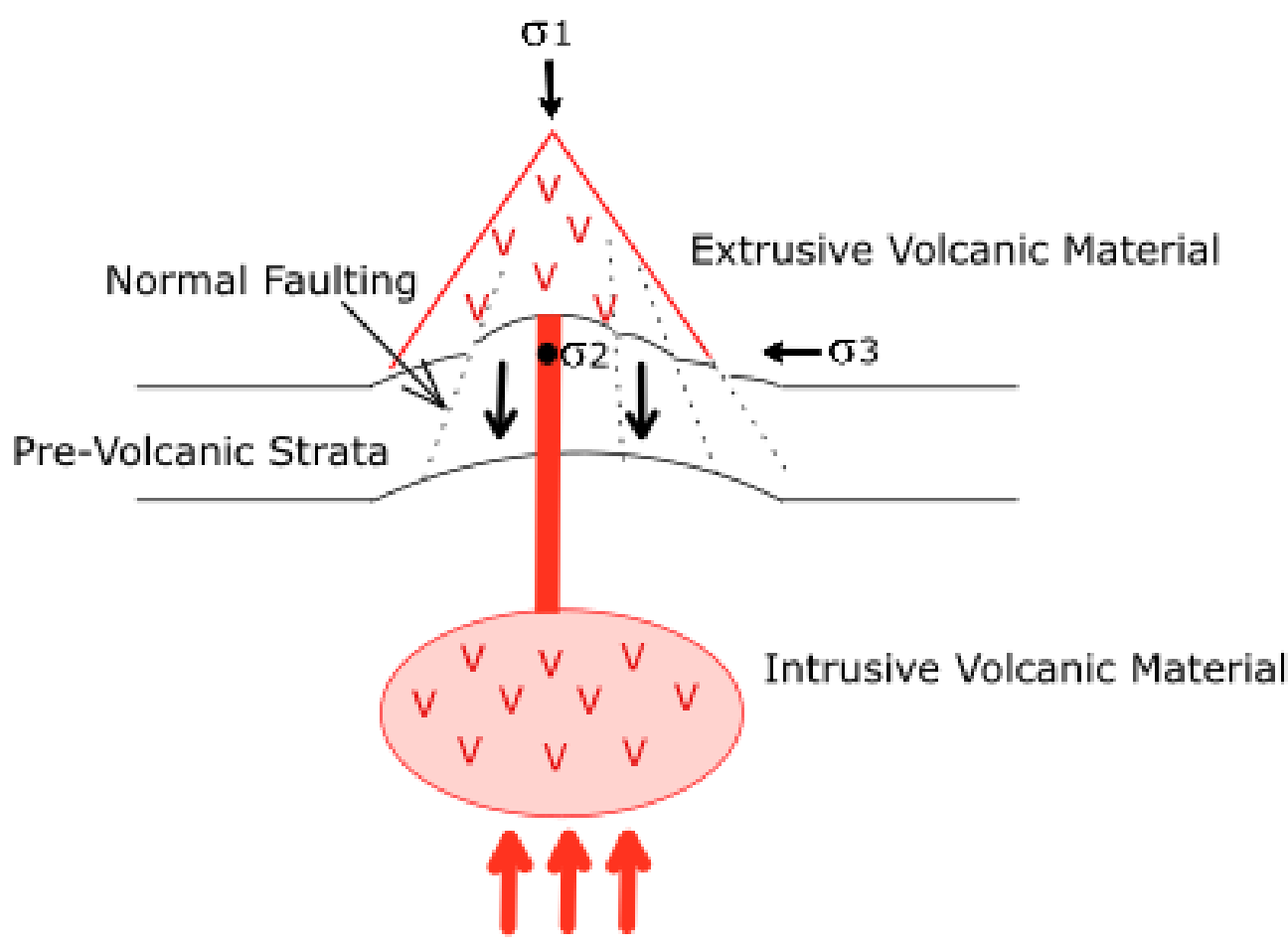

Figure 4.7. Simplified cartoon cross section for radial faulting in model 2. Radial faults are formed by the emplacement of an extrusive volcanic cone which warps down strata beneath the cone. Red arrows show the direction of magma intrusion. Thick black arrows indicate down warping of sedimentary sequence. Orientations of $\sigma_{1}, \sigma_{2}$, and $\sigma_{3}$ are shown with $\sigma_{2}$ and $\sigma_{3}$ being approximately equal.

When considering the difference between the two models, the timing of the faulting, relative to the volcanism becomes a distinguishing feature. In model 1 , faulting occurs synchronous with the intrusive volcanism and not with extrusive building of the volcanic cone. In model 2, however, faulting occurs during the building of the cone, and for a period after.

Radial faults initiated at $12 \mathrm{Ma}$, with extrusive volcanism starting $15 \mathrm{Ma}$ (Bergman, et al., 1992). Radial faulting continued until 2.5-5.5 Ma, and volcanism continued until $8 \mathrm{Ma}$ (Bergman, et al., 1992). This fault timing data suggests that model 2 is favoured in the formation of these faults. The extrusive building of the cone would have a longer lasting subsidence and stress effect than model 1, keeping the faults active for a longer period of time. 


\subsection{Tectonic faults}

Tectonic faults in the Northern Taranaki Basin strike N to NE and dip east and west, to form a regional graben referred to as the Northern Graben (King \& Thrasher, 1996; Giba, et al., 2010). These normal faults create up to $3 \mathrm{~km}$ of extension and in places the faults are reactivated Late Cretaceous normal faults (Giba, et al., 2010). The following sections describe and analyse the tectonic normal faults imaged in the Kora 3D seismic volume.

Tectonic faults in this study were defined as faults not fitting under the radial faults definition, as well as having a similar strike to that of the known basin tectonic stress regime (King \& Thrasher, 1996).

\section{$\underline{4.8 \text { Fault strike }}$}

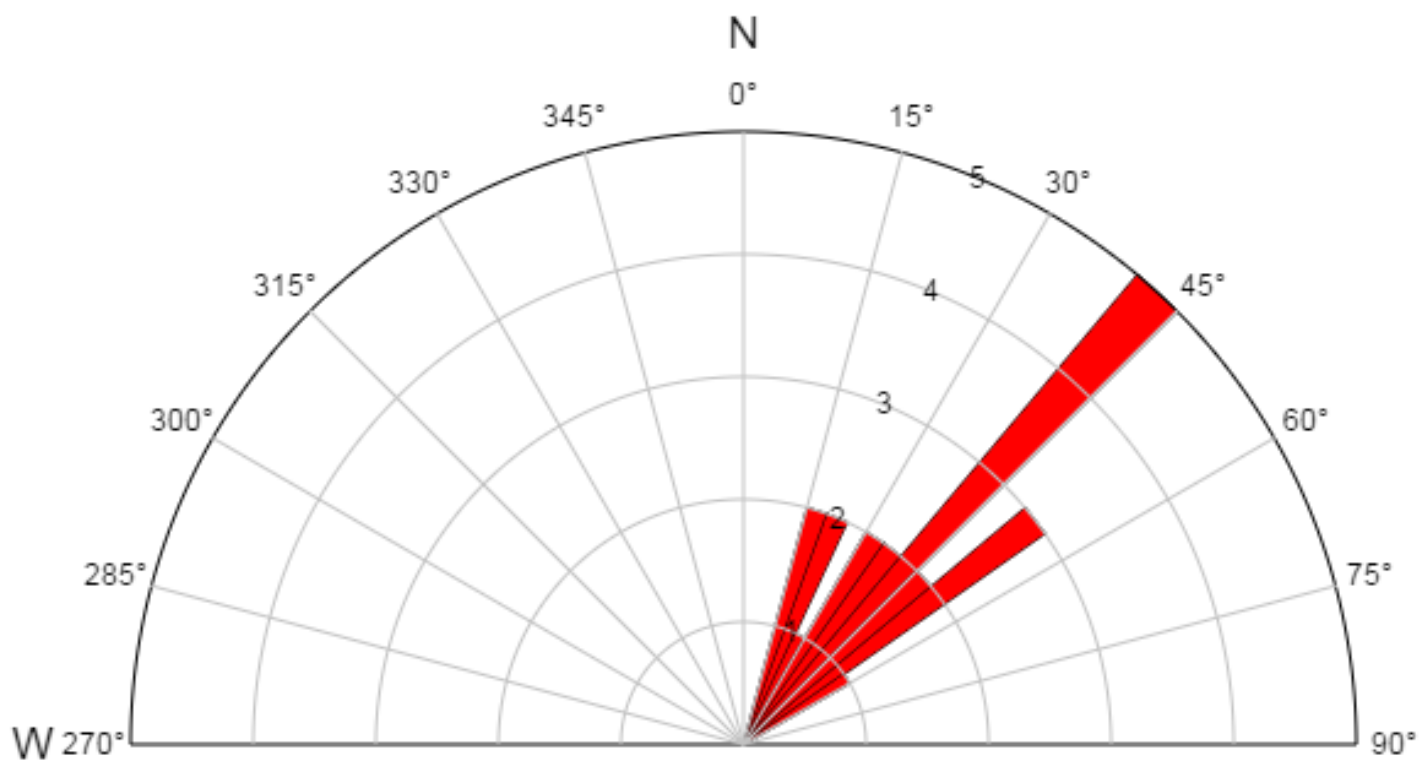

Figure 4.8. Rose plot of the strikes of the tectonic normal faults within the Kora 3D seismic reflection survey. The number of faults sampled is 33. Diagram created using Young Technology Inc software. (http://www.yongtechnology.com/yonglab/online-rose-diagram)

Figure 4.8 shows a rose diagram of strike for tectonic faults within the Kora 3D seismic reflection survey. These strikes of the tectonic faults range from $015^{\circ}$ to $060^{\circ}$ with the majority of values between $040^{\circ}$ and $055^{\circ}$. The observed fault strikes are 
comparable to those recorded throughout the Northern Graben (King \& Thrasher, 1996; Giba, et al., 2010).

\subsection{Fault length and displacements}

The length range of the tectonic faults within the Kora 3D seismic survey ranges from 5 to $25 \mathrm{Km}$. Roughly $70 \%$ of the fault lengths measured are censored meaning the true extent has not been mapped within this survey, these fault lengths represent minimum values because the faults extend beyond the boundaries of the 3D volume. Despite these censoring issues longer tectonic faults generally have larger displacements. The average displacement along tectonic faults is generally $50-150$ $\mathrm{ms}$, and can be $>200 \mathrm{~ms}$.

Tectonic faults not only differ in strike direction from radial faults, but they are also different in their length and displacement. These differences in populations, with radial faults generally having shorter lengths and lower displacements than the measured tectonic faults, lead to the conclusion that different processes have initiated and driven the two main fault types within the Kora 3D seismic survey.

\subsection{Fault initiation}

Methods for analysing the timing of initiation of tectonic faults are the same as those for radial faults. Figure 4.3 shows the timing of initiation for all faults within the Kora 3D survey, and indicates that many of the tectonic faults started to accrue displacement about $12 \mathrm{Ma}$. This timing is consistent with previous work which suggests that the majority of normal faults started around 12 Ma (Giba, et al., 2010; Giba, et al., 2012; Seebeck, et al., 2014).

There are a number of exceptions to this timing and these faults generally cut through the volcanic edifice, and have an older initiation age of $16 \mathrm{Ma}$. Figure 4.9 shows growth history plots for these "older" tectonic faults. Displacement on faults that cut the volcanic edifice were measured outside of the volcanic edifice to avoid misleading displacement due to volcanic attenuation. I believe the faults in question 
are older when compared to other tectonic faults in the study and in the surrounding area (King \& Thrasher, 1996; Giba, et al., 2010).

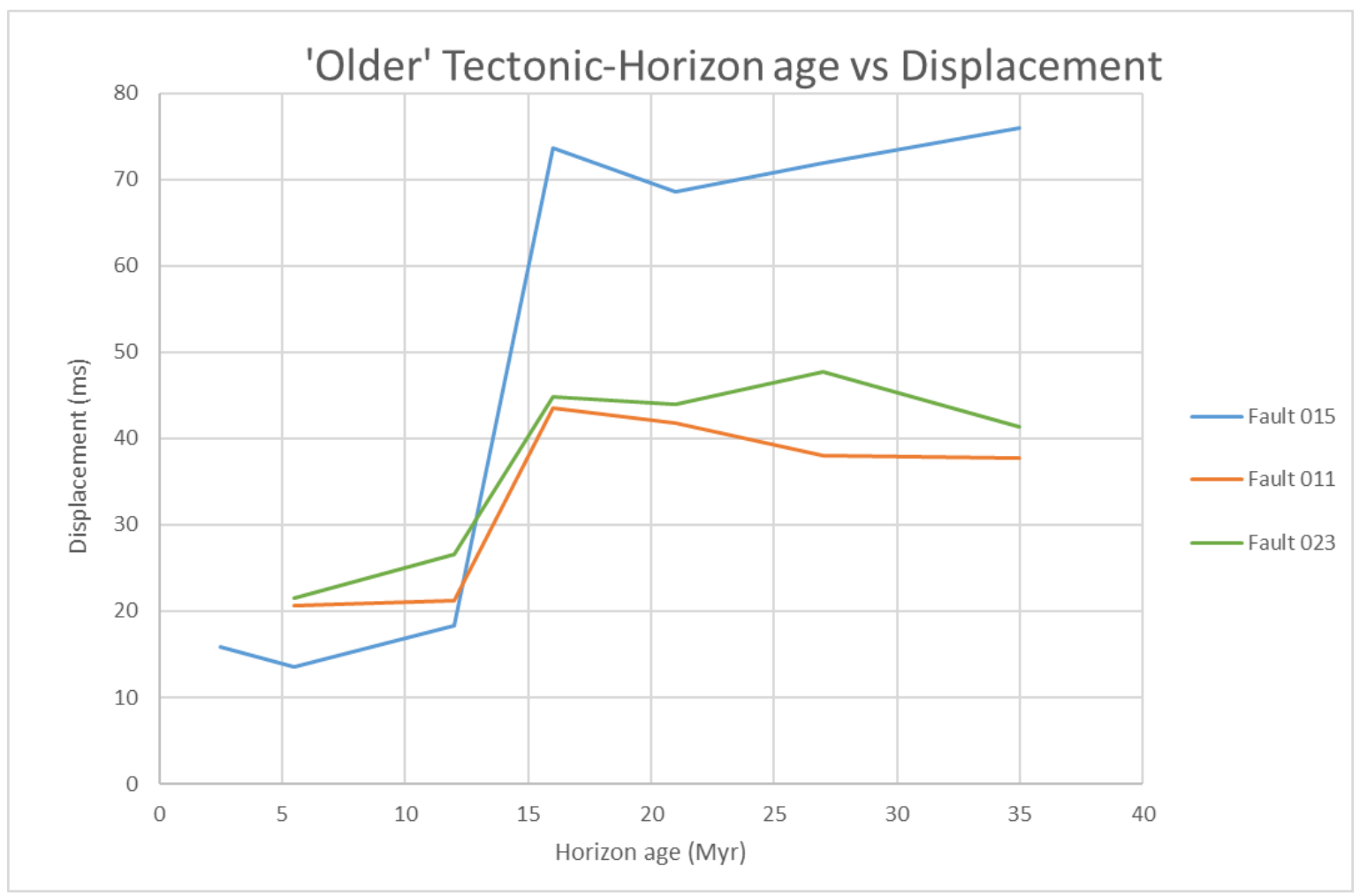

Figure 4.9. Growth curves for the tectonic faults that displace the volcanic edifice. These faults show an older age than other tectonic fault in the Northern Grabens. Fault displacement data for these faults was gathered outside of the volcanic edifice, so volcanic attenuation did not impact the results.

\subsection{Fault death}

The death of tectonic faults indicate a change in the tectonic regime in which the Kora 3D Survey is located (Jackson, 1999). Figure 4.5 shows a map of fault death ages within the study. Many of the tectonic faults within the study die at the same time(N60) 5.Ma. Only five faults have measurable displacement close to the surface suggesting that the fault have been recently active. The recently active faults are located within the volcanic edifice and in the eastern part of the survey. The recently active faults are all large in both length $(>15 \mathrm{~km})$ and in displacement (>200 ms), and are considered likely to still be active. In other normal-fault systems the largest faults are often active for the longest and cease activity last, perhaps because they are the weakest and/or the most efficient at localising stresses (Meyer, et al., 2002; Childs, et al., 2003). 
The death of tectonic faults reflects southward migration of extension, caused by clockwise rotation of the overriding Australian Plate relative and/or steepening of the subducting Pacific Plate (King \& Thrasher, 1996; Seebeck, et al., 2014).

\subsection{Tectonic history}

The tectonic faults within this survey can be used to determine the tectonic history of the Kora area and wider basin.

During rifting, extensional faults along the west coast of North Island New Zealand migrated southwards. The migration of rifting down the West Coast of the North Island is a well-documented geological event (King \& Thrasher, 1996; Giba, et al., 2013; Seebeck, et al., 2014). Using the data from this study, rifting within the Kora 3D commenced between 12-10 Ma (Fig 4.3). I believe this to be a robust result as a majority of the faults analysed show this pattern. In terms of the larger picture, the age range provided by this study is consistent with previous results (King \& Thrasher, 1996; Giba, et al., 2010; Giba, et al., 2013). Therefore, it is reasonable to assume the initiation of the tectonic faults within this study have the same initiation processes as other normal faults in the Northern Graben.

Four tectonic faults in this study are older than 10-12 Ma (Fig 4.9). These faults displace the Kora volcanic edifice, and I suggest that the edifice has had some effect on the initiation of these faults (Fig 4.3). I propose that like the radial faults, either a force from below due to magma accumulation or a gravitational force from above due to volcanic loading, caused the early initiation of these faults. To help determine the causal processes for the older faults, their ages have been analysed. According to this study the faults initiated roughly 15-17 Ma, when the Kora volcanic system was active both at depth and cone building (Bergman, et al., 1992). Therefore, it is possible that the initiation of these "older" faults was triggered by volcanic activity either intrusive at depth or cone construction at the surface. 


\section{$\underline{4.13 \text { Strain }}$}

Strain or extension was measured in a direction perpendicular to the average fault strike within the Kora 3D (Fig. 3.2). Strain was measured using the interpreted faults and horizons. Trap Tester was used to measure, calculate, and visualise the strain.

Figure 4.10 shows the calculated strain profiles for each horizon within the Kora survey. A number of patterns emerge from the graph, and the similarities between the strain curves for each horizon. Within the area of the volcanic edifice, the strain measured is significantly lower than that of the surrounding area. This is either due to the lack of geological interpretation (due to the seismic attenuation the volcanic rocks cause), or an actual lack of measurable strain on the faults that displace the edifice. For example, it is possible that small-scale faulting accommodates more of the strain budget in the cone and these smaller faults are sub-resolution, the smallscale faulting for such a scenario would not be included in the strain curves. However, three large displacement (> 150 ms) (Fig. 4.10) faults displace the volcanism. These faults are young and accommodate a large majority of the measurable strain within the volcanic edifice. The main displacements along these faults can be observed in the strata younger than the volcanic cone. 


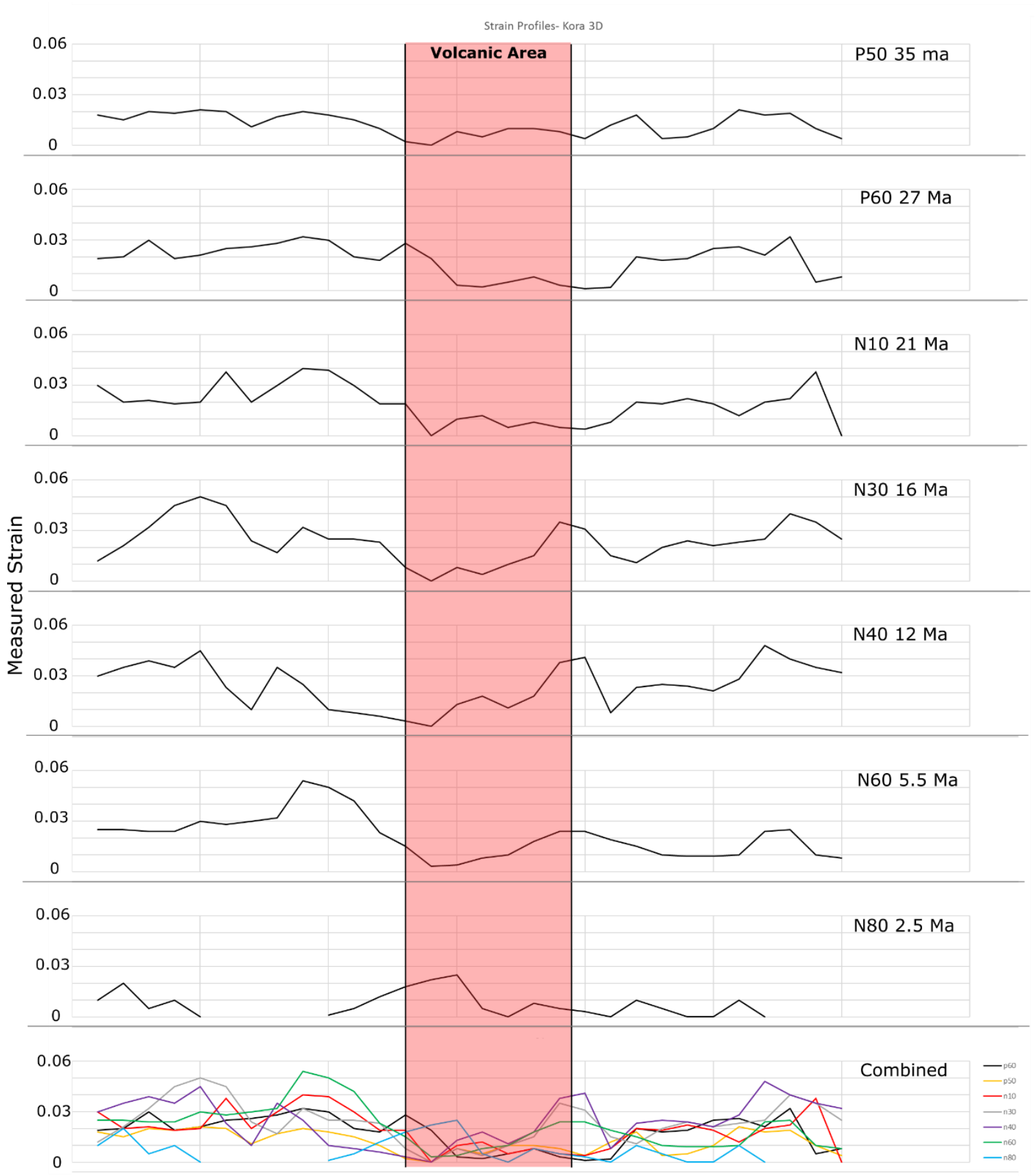

Figure 4.10. Strain profiles for mapped horizons within the Kora 3D. Also marked on the graph is the location of the volcanics in relation to the graph. Strain profiles created by measuring mapped displacement across recorded faults within the Kora 3D. Strain profiles were created normal to the strike of the tectonic faults to capture true displacement along a majority of faults. Profiles move up from the South of the survey to the North.

Strain curves are relatively similar outside the volcanic area, retaining the same pattern for each horizon. There seems to be no measured sign of strain localisation or migration though the study area over time. 
Measuring strain on each horizon provides an opportunity to examine the history of tectonic faulting within the Kora 3D survey (Meyer, et al., 2002). The summation of extension provides an estimate of the total deformation each horizon has undergone (Table 4.11). N40 has the largest recorded amount of strain of 0.727 and is $12 \mathrm{Ma}$ old. The decrease in strain on the $\mathrm{N} 60$ and $\mathrm{N} 80$ horizons above $\mathrm{N} 40$ probably reflect the fact that most faulting initiated at N40 time and younger horizons record less of the faulting history. The decrease in recorded strain, partially below N30 may partly reflect a decrease in resolution with increasing TWTT.

\begin{tabular}{|c|c|c|}
\hline Horizon & Horizon Ages (Ma) & Total Strain \\
\hline N80 & 2.5 & 0.174 \\
N60 & 5.5 & 0.632 \\
N40 & 12 & 0.727 \\
N30 & 16 & 0.701 \\
N10 & 21 & 0.569 \\
P60 & 27 & 0.5329 \\
P50 & 35 & 0.372 \\
\hline
\end{tabular}

Table 4.11. Horizons and corresponding strain summation measurements for corresponding horizon.

\subsection{Decollement and mass transport complex}

The seismic characteristics that define a mass transport complex (MTC) were identified during the seismic interpretation process.

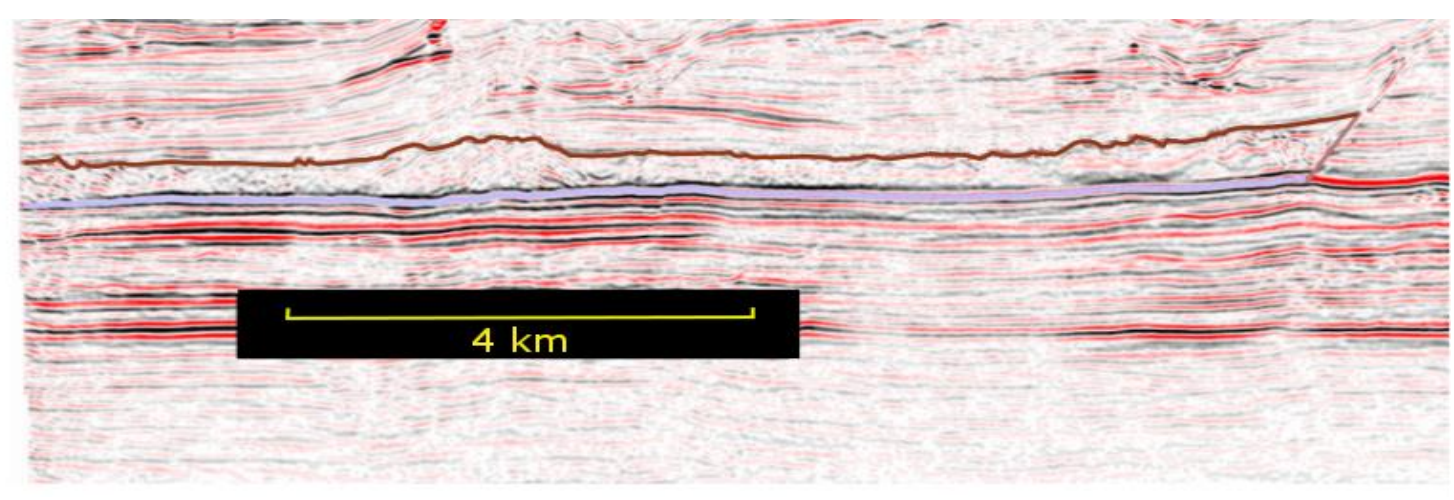

Figure 4.12. Seismic characteristics of the decollement. A mass transport complex (see brown outline) sliding on the decollement surface.

The seismic characteristics of this feature can be seen in figure 4.12 and 4.13 . MTC generally have a weak to moderate amplitude response, with disconcordant 
reflectors. The disconcordant reflectors are the most defining feature of this layer and easily allow mapping of the MTC across the Kora 3D. Above and below the MTC, the seismic section comprises parallel seismic reflectors.

This MTC is present over nearly half of the Kora 3D, and is found on the north and south side of the Kora volcanic edifice. The map distribution of the MTC can be observed in Figure 4.14. The north and south boundaries of the MTC seem to be abrupt, linear, and nearly vertical (Fig. 4.1 and Fig 4.14).

Decollements at the base of MTC's are an important component of these systems and these structures have been observed worldwide (Laubscher, 1987).

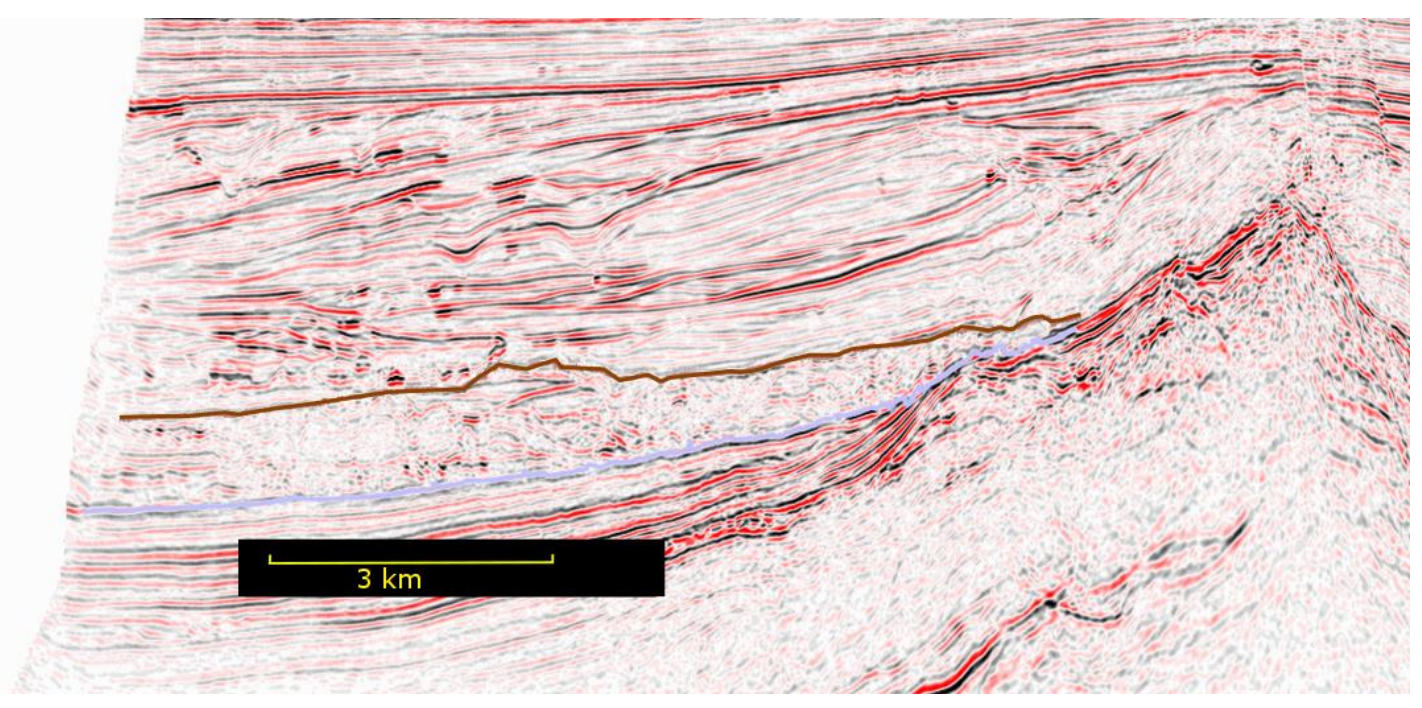

Figure 4.13. Seismic characteristics of the MTC and the decollement surface on the western flanks of the volcanic cone

Decollements typically are parallel to bedding and occur along weak layers of rock, such as a shale or mudstone (Twiss \& Moores, 2007). In this study, the mapped basal contact of the disrupted reflectors is believed to be a decollement. Many decollements also have a ramp up or down through stratigraphy at the head and/or toe of the failure, often producing a curved decollement. In this survey, we only image the headwall of the MTC which is typically a vertical and abrupt feature similar to a ramp (Fig 4.12) (Twiss \& Moores, 2007). 


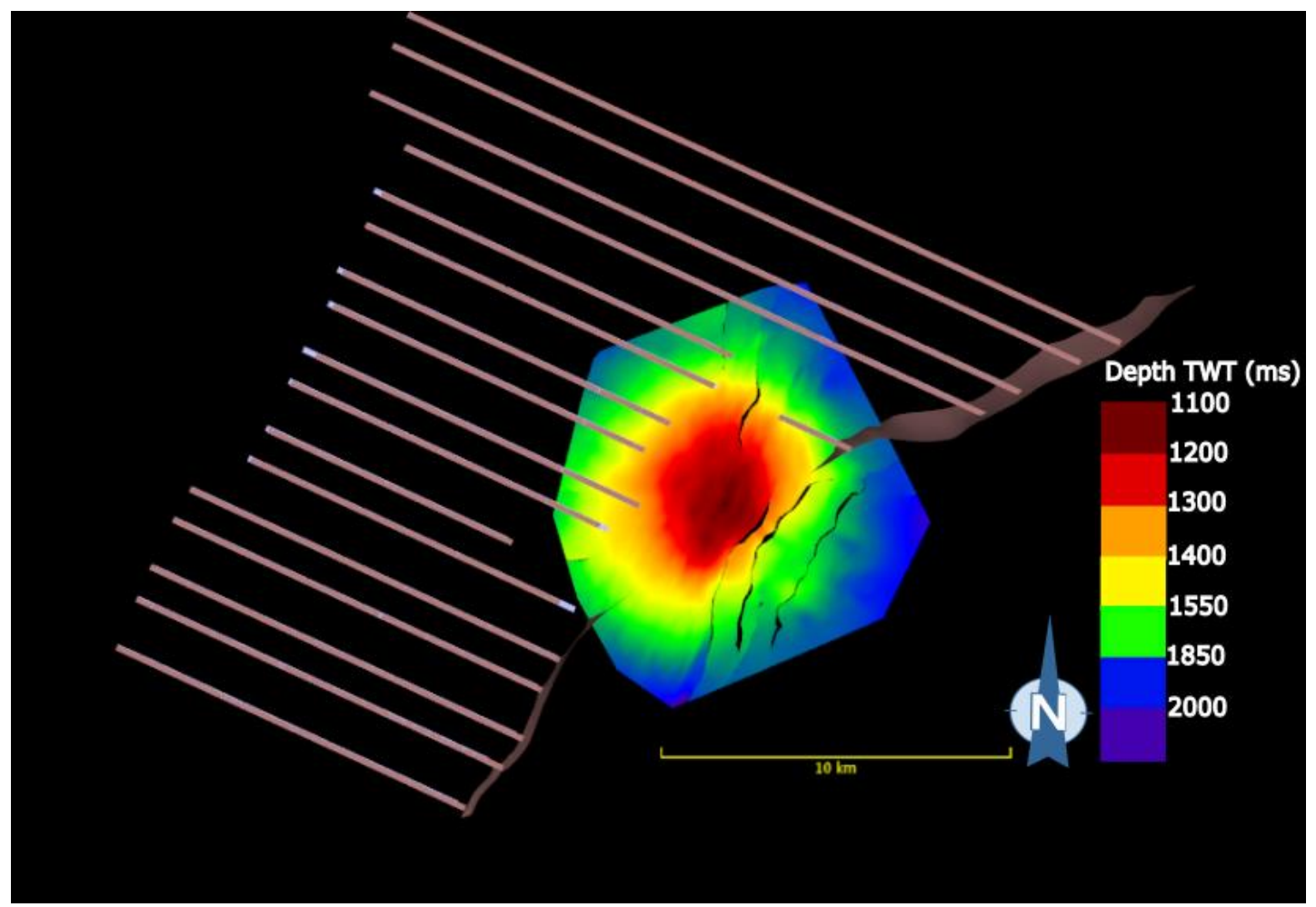

Figure 4.14. Extent of the mapped decollement feature. The coloured grid shows the volcanic cone. Brown polygon shows bounding fault, and brown lines shown mapped extent.

The age and lateral extent of the decollement feature suggest that the MTC is the same age as the Kora volcanic cone. The age was determined by mapping boundary reflectors to the nearby Ariki-1 well. The slip on the decollement could be due to slope steepening associated with volcanic intrusion or growth of the volcanic cone (Denlinger \& Morgan, 2014). However, the decollement is not limited to just within the vicinity of the Kora Volcanic edifice (Fig. 4.14). Another possibility is that the regional paleobathymety at the time of MTC failure could have driven the decollement. Whatever the processes underlying the formation identified it is clear that the feature is primarily gravity driven with slip on a weak decollement surface (Laubscher, 1987).

\subsection{Faults and hydrocarbon prospectivity}

Oil was discovered and flow tested from Kora-1A in 1988 (ARCO Petroleum, 1988), since this period the Kora volcanics have been under investigation as an oil and gas prospect. Four wells have been drilled into the volcanic edifice itself, with only Kora1A flowing with oil both in the volcanic deposits and underlying Tangaroa Sandstone. 
As well as previous oil discoveries, bright spots haven been mapped by OMV in 2011 (OMV New Zealand Ltd, 2011). The high amplitude bright spots are located in strata overlying the volcanic cone, and are considered within the petroleum industry to be direct hydrocarbon indicators (DHI'S).

Due to the faulting of the volcanic cone and proximity of faults to the bright reflectors, it has been assumed that faults have played a significant role in the migration and trapping of hydrocarbons within the Kora volcanic centre area. In this section I will further explore faults interaction on hydrocarbon movement.

To help explain how oil charged the reservoir intercepted by the Kora-1A well, a model was developed by OMV involving oil migration from source rock along a fault passing though the volcanic edifice (OMV New Zealand Ltd, 2011) (Fig. 4.15). The fault has been active recently (within the Late Quaternary) which combined with the dominance of extension, leads to the inference that the fault is 'open' allowing the migration of hydrocarbons along it. The fault is large with a maximum displacement of $>200 \mathrm{~ms}$, and displaces the sequence from near the sea floor down to Cretaceous strata. The size of this fault may allow hydrocarbons from the underlying Palaeocene and Cretaceous source rocks to travel upwards into the Tangaroa sandstone and Kora volcanic tuffs. The fault may also allow hydrocarbon movement into the shallow PlioPleistocene strata, causing the bright reflectors observed at these stratigraphic levels.

High amplitudes have been mapped above the volcanic cone in this study at multiple stratigraphic levels from $840 \mathrm{~ms}$ to $480 \mathrm{~ms}$ TWTT. The DHI'S are bound by a fault to the east suggesting that the fault is interacting with the hydrocarbons causing the DHI (Fig 5.4). Because the DHI's are located close to the surface and do not represent a full conclusive DHI amplitude response (OMV New Zealand Ltd, 2011), it is interpreted that hydrocarbons have migrated upwards and leaked out of the system.

Data from this study suggest parts of the faults are 'open' and provide vertical migration pathways for hydrocarbons. Cross-fault permeability is assumed to be low (Reilly, et al., 2016), and migration of hydrocarbons along a fault zone occurs through fractures within the fault zone. These fractures increase vertical permeability within 
the fault zone, giving the 'open' fault conclusion. This is supported by the mechanical clay injection potential (MCIP) and sedimentary analysis on the Kora-1A drill core. The Kora-1A core sampled a fault gouge with a $26.4 \%$ porosity and a permeability of 9.33 mD (OMV New Zealand Ltd, 2011). $9.33 \mathrm{mD}$ is generally not enough to allow large flow of hydrocarbons (Tiab \& Donaldson, 2004), however, the MCIP method only measures permeability in a very small zone and does not take into account the permeability through fractures in the larger fault zone. Vertical migration along faults allows the possibility that other prospects within the Kora volcanic tuffs are charged by a source rock below.

If the faults within the Kora prospect area are open, it is surprising to see no oil shows in Kora-4. This may be due to the main Kora fault (which has not been MCIP tested in Kora-1A drill core) being sealed to lateral flow. If this fault was sealed it would not allow hydrocarbons from the deep source kitchen in the east to travel into Kora-4 on the west side of the fault (Fig. 4.16) (OMV New Zealand Ltd, 2011). This finding is consistent with the assumption that cross-fault permeability is low. 


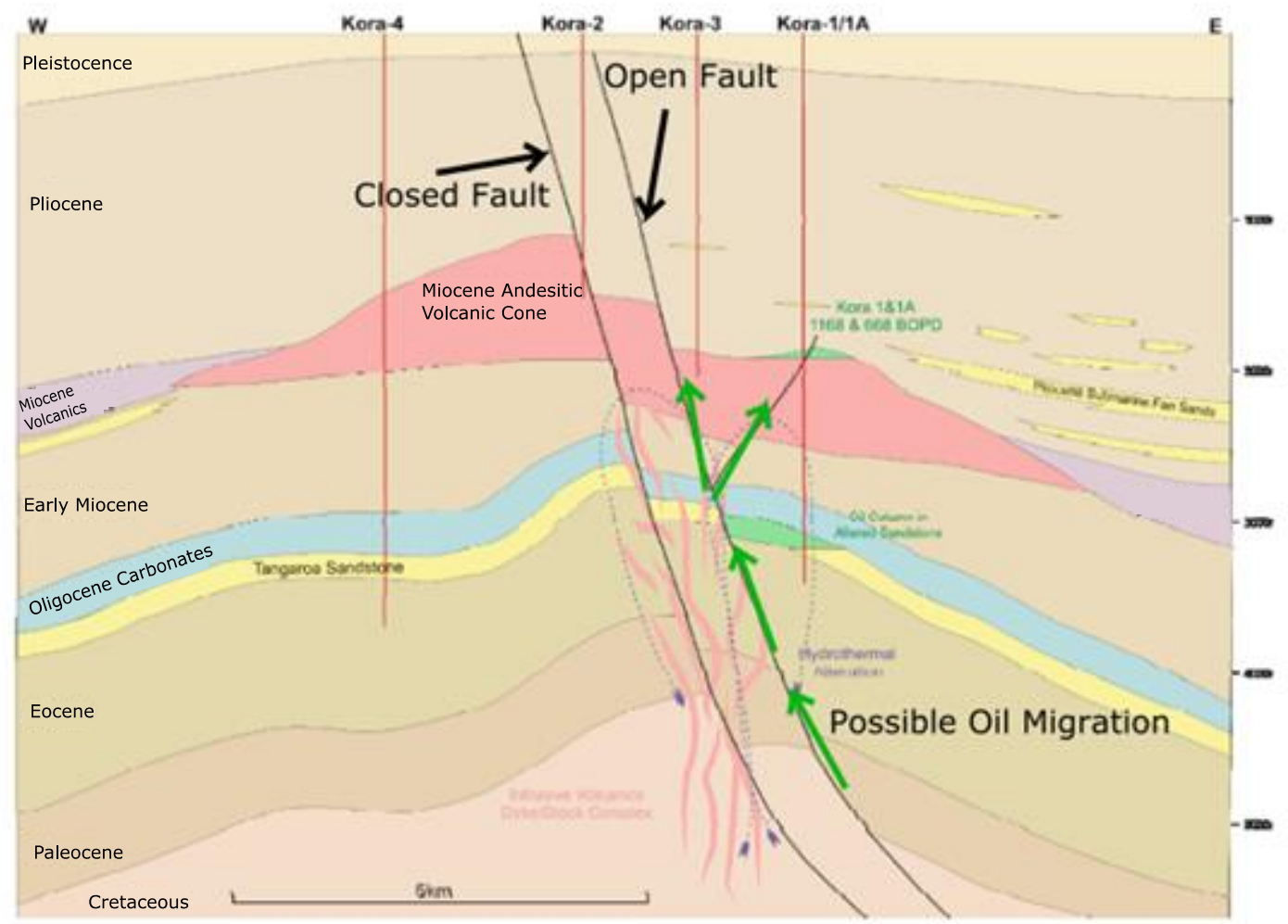

Figure 4.15. Cross section across the Kora prospect modified from OMV PR report 4318 (2011). This cross section shows the possible migration pathways of hydrocarbons along faults, and sealing of the main kora fault. Fault seal is interpreted to prevent charge in either Kora-2 or Kora -4.

As many of the Kora volcanic tuffs (making up the reservoir for the Kora prospects) are vertically or laterally heterogeneous, migration through the reservoir is only possible through faults and fractures. If all faults are 'open' to vertical and lateral flow within the Kora prospect area, the size of the fetch for these prospects increases compared to if the faults were closed to vertical and lateral flow. This, therefore, increases desirability of these prospects for oil and gas exploration. If faults are closed to lateral flow but open to vertical flow, I suggest and consistent with wider evidence (Reilly, et al., 2016), this again has impacts on the fetch distance for the Kora prospects. For example, the fetch distance for many prospects located on the west side of the volcanic edifice, which depend on lateral flow of hydrocarbon through the fault zone, halve in size if the main Kora fault is sealing to lateral flow (OMV New Zealand Ltd, 2011) (Fig. 4.16). 

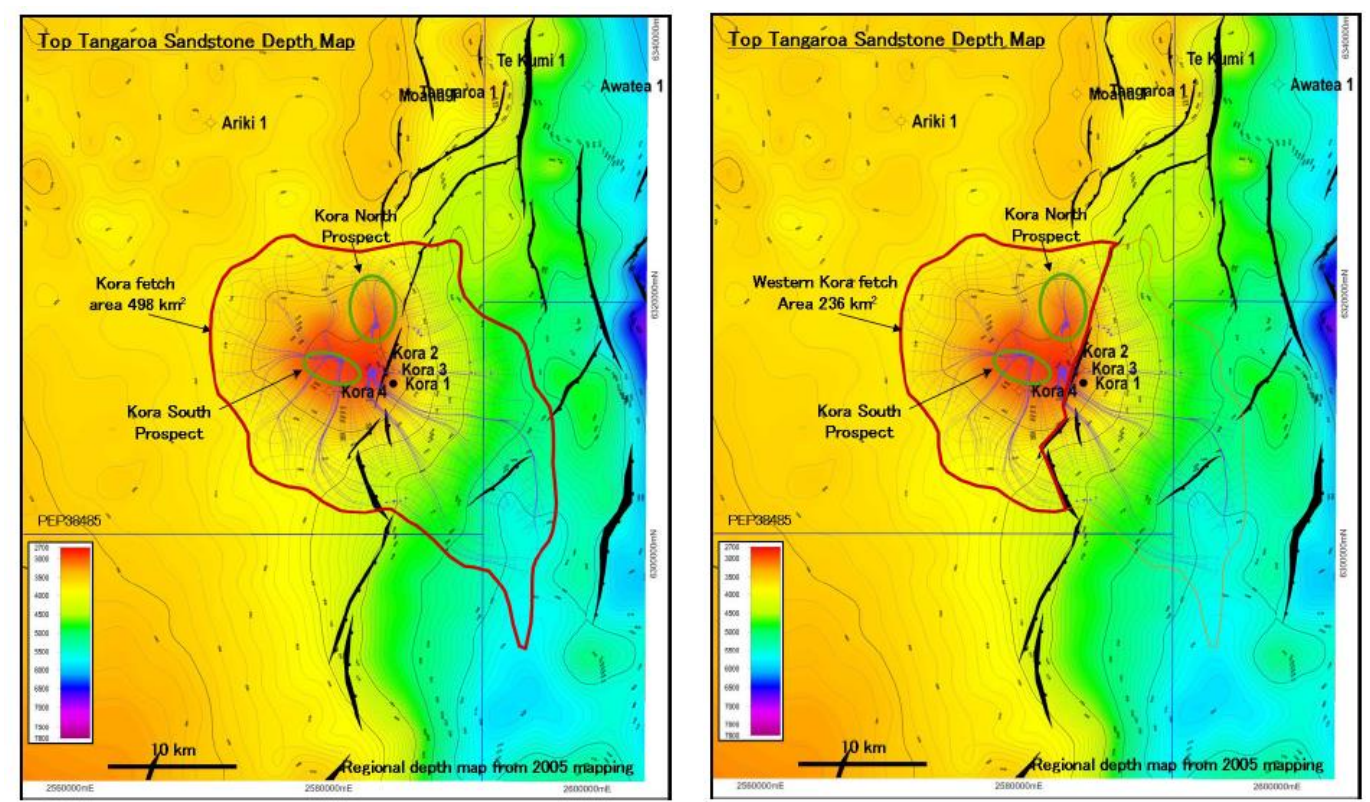

Figure 4.16. Maps showing the fetch size for two possible Kora prospects considered by OMV. (OMV PR report 4318,2011 ). The fetch distance significantly decreases if the main Kora fault is sealing to lateral flow (right image). If the fault is open to lateral flow (left image) the fetch size reaches down into the deep kitchen area to the east.

\section{$\underline{4.16 \text { Conclusions }}$}

Conclusions for the fault analysis in this study are as follows;

I. Two fault groups were identified: radial faults and tectonic faults. Classification of faults was based on strike and proximity to the primary volcanic vent.

II. Strikes and displacements were analysed and further used to show disparities between the two main fault groups.

III. Formation of radial faults is due to a local stress induced by volcanic and magmatic processes.

IV. Model 2 depicting the formation of radial fault due to an emplacement of a volcanic cone, is the preferred model for the Kora 3D radial faults. This is based on the dating of extrusive volcanism and active periods of the radial faults.

V. Tectonic faults formed in conjunction with others in the Northern Graben, and share the same formation processes. 
VI. Older tectonic faults are formed due to induced stress by volcanic and magmatic processes.

VII. Strain was measured and displayed showing no localisation or migration of strain. The volcanic area has no measurable strain. The lack of measurable strain is due to either a lack of visible offset data, due to volcanic attenuation, or small-scale faulting below seismic resolution.

VIII. A mass movement feature and associated slip surface were mapped. Theories for formation are still open, however, it is gravity driven.

IX. Fault zone properties within the Kora prospect area impact petroleum prospectivity of the area. I conclude from the distribution of oil shows and amplitude anomalies that faults in this area are open to vertical flow, but closed to lateral flow. 


\section{Chapter 5}

\section{Volcanics in the Kora 3D}

\section{$\underline{5.1 \text { Introduction }}$}

Kora volcano is part of the Taranaki-Coromandel volcanic arc which was primarily active during the Miocene and youngs to the south and east (Herzer, 1995; Giba et al., 2013; Seebeck et al., 2014). The volcano is well imaged by the Kora 3D dataset and this chapter examines the geometry of the volcanic cone, its age, and geological history. The results are used to elaborate discussions on the regional tectonics and volcanism of the Northern Taranaki Basin. Kora volcano is a potential target for oil and gas exploration and the implications of the results for hydrocarbon exploration are also considered in this chapter.

Kora volcano is buried by Miocene strata of the Northern Taranaki Basin. It appears to have retained much of its original volcanic form suggesting that it has not been subject to erosion and probably remained submerged during its burial (ARCO Petroleum, 1988; Bergman, et al., 1992; Giba et al., 2013).

The data for this chapter are the 3D seismic volume and four wells that penetrate the cone. The seismic reflection data provide information on the geometry of the cone (and its relationships to faulting and basin-fill strata), while well data and core samples provide data on the ages, lithologies, and reservoir properties (e.g., porosity and permeability) of the volcanics and enclosing sedimentary rocks. These data suggest that Kora was an intra-arc volcano that formed approximately between 8 and $19 \mathrm{Ma}$ (Bergman, et al., 1992; Giba, et al., 2013). 


\section{$\underline{5.2 \text { Cone morphology and dimensions }}$}

The top of the cone is marked by a high amplitude reflector that images the boundary between basin strata and volcanic rocks (Fig. 5.3). A 3D model of the top of the cone presented in figure 5.1. Unlike the top of the volcanic cone, the base of the cone and sedimentary strata that underlie it are poorly resolved in the seismic reflection volume (Fig. 5.3). From the 3D model, both the general cone morphology and secondary irregularities can be observed, permitting conclusions to be drawn on the type of volcanism, the processes that built the cone, and the tectonics associated with volcanism.

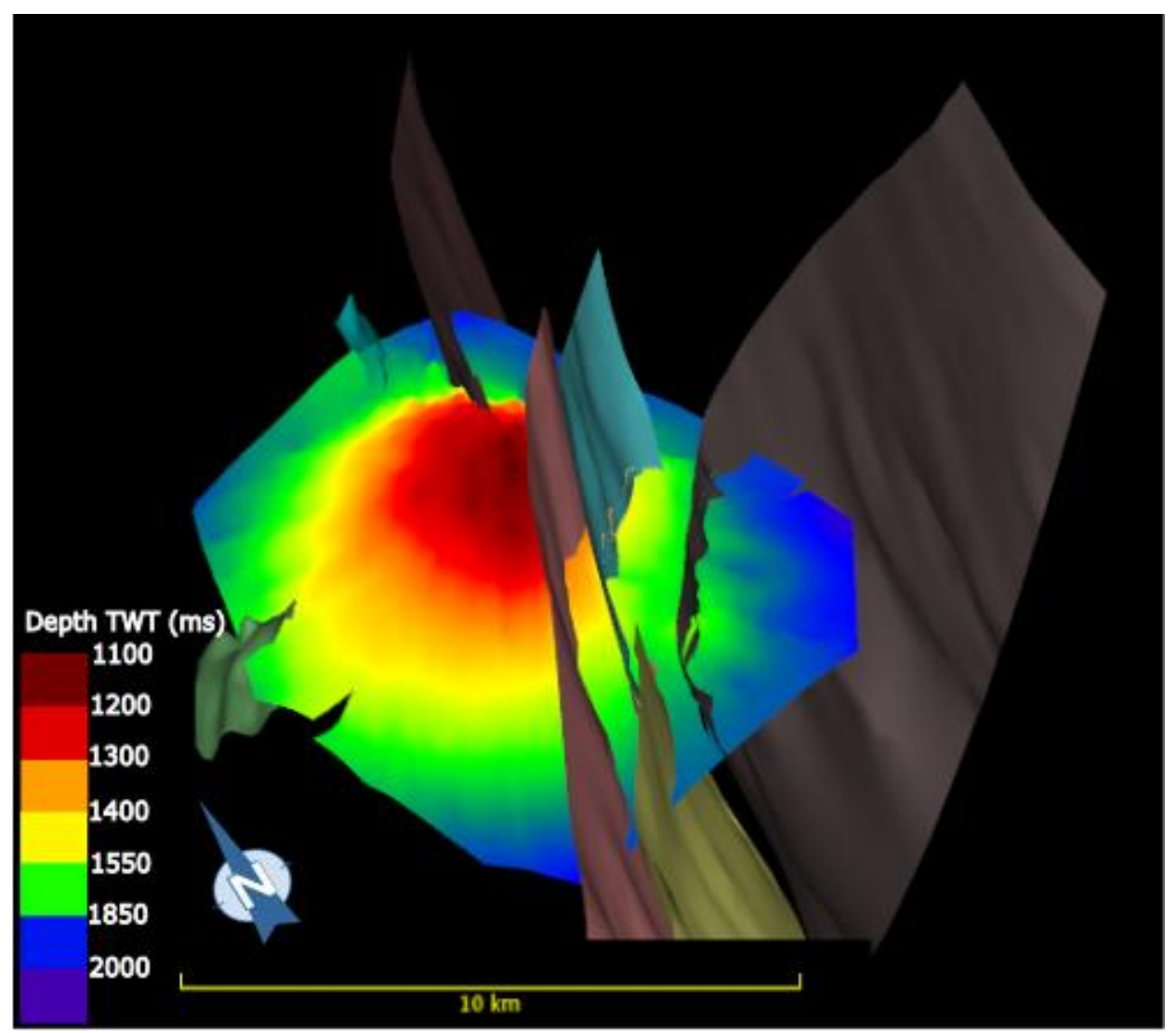

Figure 5.1. 3D model of the Kora volcanic cone and intersecting normal planes. Seismic mapping produced both the cone and fault planes. The cone and fault planes is shown with $4 x$ vertical exaggeration. 


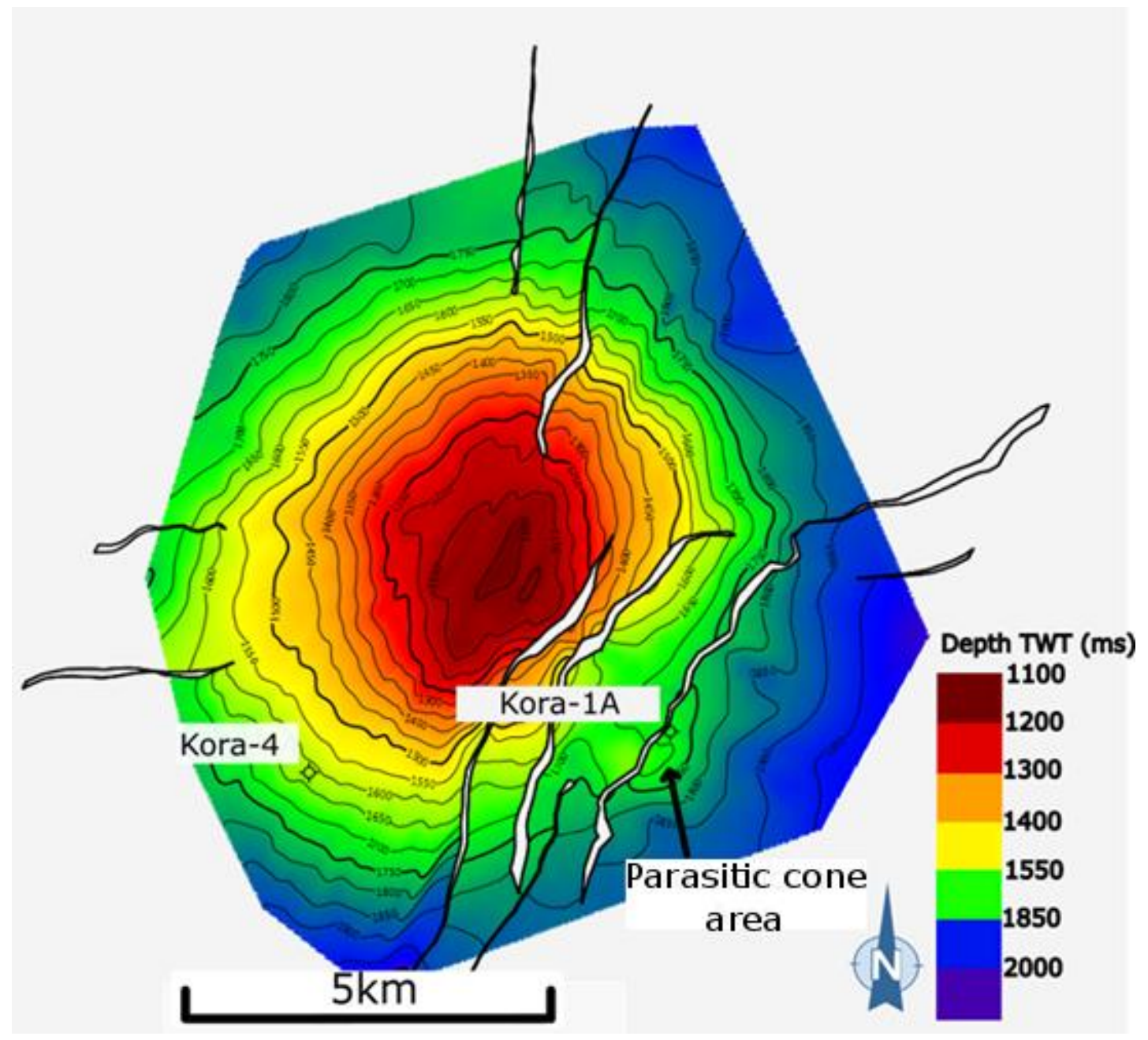

Figure 5.2. Map view of interpreted volcanic cone and intersecting faults. Wells are labelled with location shown. Pyroclastic cone can be seen in the same location as Kora-1A well and is labelled accordingly.

Figure 5.2 shows a map view of the volcanic cone. The cone does not appear to have been significantly eroded and preserves much of the original volcanic form. Contours on the top of the volcanic cone are at $50 \mathrm{~ms}$ intervals, and faults are shown as polygons with black outlines and white fill where the width of the polygon is proportional to fault heave. In detail the main cone has at least one parasitic cone on the south west side of the main cone, although this has a height of $100 \mathrm{~ms}$ and cannot be clearly observed at the resolution of Figures 5.1 and 5.2. The slopes of the volcanic cone are, on average, typically $18-20^{\circ}$ (Bergman, et al., 1992). The volcanic cone has a height of $950 \mathrm{~ms}$ or $940 \mathrm{~m}$ using an average velocity of $993 \mathrm{~m} / \mathrm{s}$ for the sequence above the volcanics (OMV New Zealand Ltd, 2011). Bergman (1992), estimates the total thickness of the Kora volcanic deposits to be up to 800 meters thick beneath the apex of the cone. The cone has a diameter of $10 \mathrm{~km}$ from east to 
west and $13 \mathrm{~km}$ from north to south, with a slight elongation in a NNE direction subparallel to the strike of normal faulting. The non-circular shape of volcanic cones is common in the Taranaki Basin, although the elongation direction is not always subparallel to faulting (King \& Thrasher, 1996; Giba, et al., 2013). The slope-angles and the diameter to height ratio of 7.6:1 (average diameter $11.5 \mathrm{~km}$ and height $\sim 1.5 \mathrm{~km}$ suggest that the Kora cone is a dome or composite shaped volcano (USGS, 2011).

\subsection{Age of Kora volcano}

Dating the volcanic cone is important for determining the geological history of volcanism and the basin. Dating the volcanic activity is also paramount when working with temporal relationships between volcanism and faulting. The cone has been dated by Bergman et al., (1992), using ${ }^{40} \mathrm{Ar}-{ }^{39} \mathrm{Ar}$ of volcanic deposits sampled in the Kora wells, and by Giba et al., (2013) using the age of strata enclosing the cone to constrain the timing of its construction. The present study follows the methodology of Giba et al., (2013) (originally outlined in Herzer, 1995) and uses detailed interpretation of the Kora 3D seismic volume together with improved age resolution of seismic reflectors to constrain the timing of volcanism. This new data help refine (and test) the established age of the volcano.

Bergman et al., (1992) dated andesitic tuffs sampled from core in four Kora wells (Kora-1A, Kora-2, Kora-3, and Kora-4). Dating used twelve K- Ar (conventional) and ${ }^{40} \mathrm{Ar}-{ }^{39} \mathrm{Ar}$ (thermal release) analyses to examine the age of the Kora volcanic deposits. The resulting dates range from 8 to $20 \mathrm{Ma}$ with uncertainties ranging from $0.5 \mathrm{Ma}$ to 4.0 Ma for all 12 samples. The majority of the dates were between 16 and $12 \mathrm{Ma}$ suggesting that the primary interval of cone building occurred at this time. Based on the radiometric dating, intrusive emplacement of melt is believed to have commenced at 19-20 Ma, with volcanism becoming extrusive at 15-17 Ma. Given the available dates and their uncertainties, the youngest possible age for the cone is 8 Ma.

The ages of 29 volcanoes from throughout the Northern Taranaki Basin (including Kora) have been determined and collated by Giba et al. (2013). Giba et al., (2013) used seismic stratigraphic methods developed by Herzer (1995), already published 
K-Ar dates, and dates from biostratigraphic information from wells to determine ages of the 29 volcanic centres. These seismic stratigraphic methods include mapping the onset of onlap of seismic reflectors of basin-fill strata onto the cone. These onlap relationships are interpreted to primarily reflect burial of the cone, with the onset of onlap marking the transition from cone construction to cone burial (i.e. the cessation of volcanism). The onset of volcanism is constrained by the age of seismic reflectors on which the cone rests. As seismic reflectors beneath the cone are generally poorly imaged the onset of volcanism is generally more difficult to constrain than the cessation of volcanism (Fig 5.3). Mapping the sedimentary strata that enclose the volcanic edifice at Kora suggests that it formed between $~ 34$ and $8 \mathrm{Ma}$ (Giba et al., 2013). The $34 \mathrm{Ma}$ age is constrained by strong reflectors that can be correlated basin wide and indicate the location of Oligocene strata. Based on the stratigraphic position of these Oligocene strata relative to the mapped cone Giba et al. (2013) believe that the $\sim 34$ Ma strata significantly predate the volcano and they adopt the maximum age of volcanism from Bergman et al., (1992).

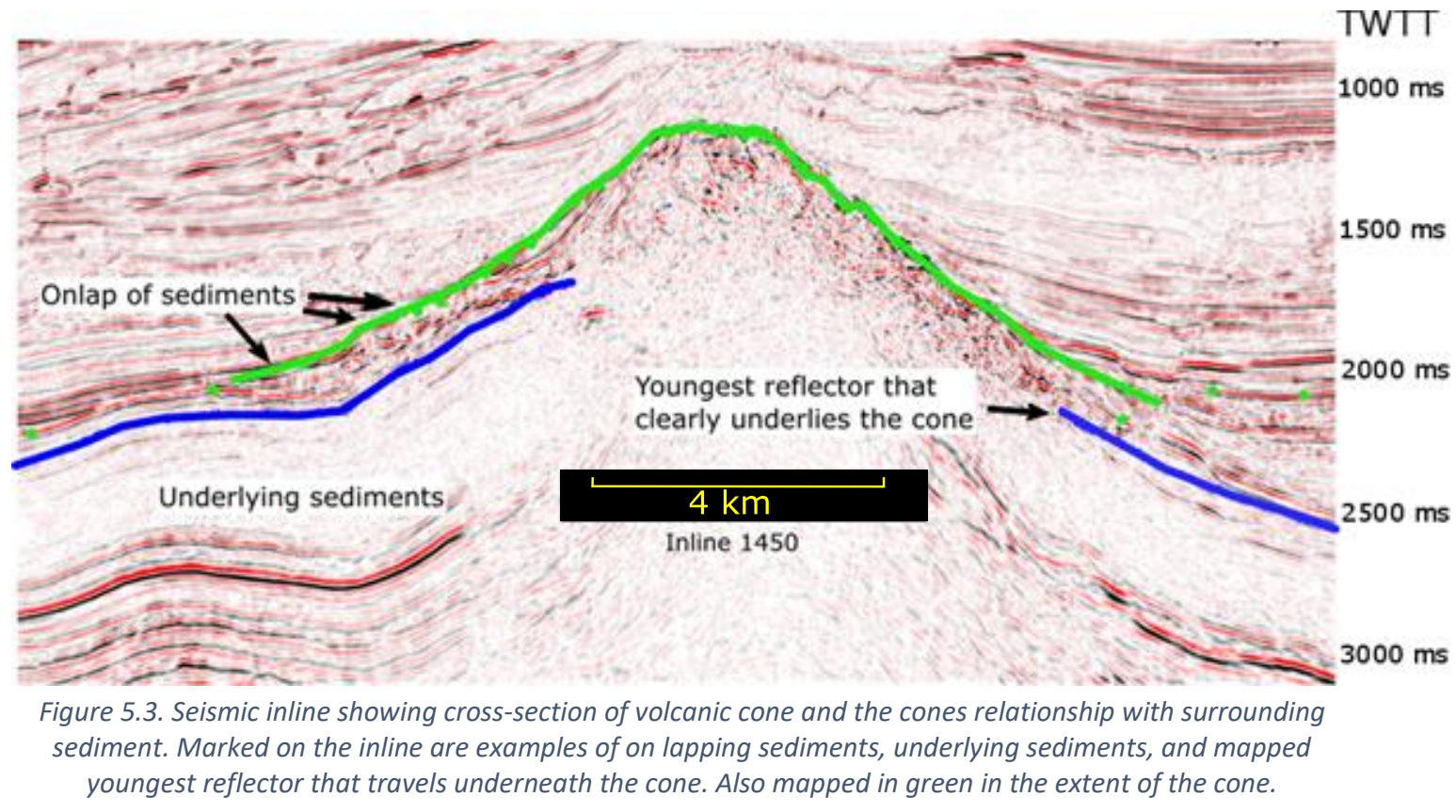

In this study, age constraints for the formation of Kora volcano have been determined using the seismic stratigraphic method developed by Herzer (1995), and utilised in Giba et al., (2013). The age of the volcano is bracketed by determining the stratigraphic position of the oldest seismic reflectors that onlap the volcano (for the death of the Kora volcanism), and the youngest reflectors that clearly underlie it (to 
show initiation of the Kora volcanism) (Fig. 5.3). The age of these key reflectors has been estimated by correlating them to four wells (Kora-1A, Kora-4, Ariki-1, and Tangaroa-1) (Fig. 3.1), where the ages of horizons are primarily determined by biostratigraphic dating (Hayward, 1986; Bergman, et al., 1992; Strong \& Crampton, 1996; Waghorn, et al., 1996; GNS Science, 2002; Hansen \& Camp, 2004; Strong, 2006).

The horizon immediately underlying the volcanic cone has been correlated to the Ariki-1 well at the Altonian NZ stage with a biostratigraphic marker PI this gives an estimated age of 16-19 Ma, and to the Tangaroa-1 well in the Early PI (i.e. 18-19 Ma). Collectively these two dates suggest an age of 18-19 Ma for the onset of volcanism. Given uncertainties in the location of the key reflector(s) beneath the volcanic cone, and in the age determinations in the wells, the uncertainties of this age are estimated to be about $\pm 2 \mathrm{Ma}$, with the age of onset of volcanism mostly likely between 16 and $21 \mathrm{Ma}$. The horizon marking the cessation of volcanism has also been correlated to the Ariki-1 and Tangaroa-1 wells, where it has an estimated age of $\sim 8 \pm 1 \mathrm{Ma}$. Collectively these dates suggest that volcanism occurred between about 19 and 8 Ma. These ages are comparable to the published results of Bergman et al., (1992) and Giba et al., (2013). They suggest that Kora volcanism was active for 8-14 Myrs, and was relatively long lived compared to other volcanoes in the basin (Bergman, et al., 1992; Giba, et al., 2013).

\subsection{Origin of volcanism}

The Kora volcanic edifice is one of many volcanic cones found in the North Island of New Zealand and surrounding offshore basins (e.g., Ballance et al., 1976; Herzer, 1995; Wilson, 1995; King and Thrasher, 1996; Hayward, et al., 2001; Townsend, et al., 2008; Booden, et al., 2011; Seebeck et al., 2014). Many of these volcanic centres are parts of ancient and active volcanic arc systems formed in response to the rise of fluids from the westward-subducting Pacific Plate. Over the last 10-15 Ma, the arcfront appears to have migrated southeast to its present position along the eastern edge of the Taupo Volcanic Zone (TVZ) (Seebeck, et al., 2014). Kora volcano is part of 
the Coromandel-Taranaki arc which trends approximately NNE and initiated at about 15-20 Ma (e.g., Herzer, 1995; Seebeck et al., 2014).

The geometry of the arc, its relationship to the subducting plate and the chemistry of the volcanic rocks provide insights into the composition of the magma that produced Kora volcanism and its tectonic setting (Bergman, et al., 1992; King \& Thrasher, 1996; Sigurdsson, et al., 2015). Multiple data sets from the four wells drilled into the volcanic edifice provide samples for isotope and mineralogical analysis of the Kora volcanic centre (ARCO Petroleum, 1988; Bergman et al., 1992). Kora has a typical depleted mantle isotope ratio for $\mathrm{Sr}$ and $\mathrm{Nd}$ (it is one of the most depleted andesites in the Taranaki Basin), which indicates that there was little interaction between the melt and seawater or radiogenic crust (Bergman, et al., 1992). Andesites from cores within the Kora volcanic edifice show high Al and low to medium $\mathrm{K}$ calc-alkaline. The Kora mineralogy is normal calc-alkaline and does not support previous suggestions that it comprises high potash andesites (King, 1990). The calc-alkaline chemistry suggests that the Kora andesites are more indicative of intra arc rather than back arc volcanism (Bergman, et al., 1992). Independent of the intra-arc interpretation trace elements in the volcanic tuff suggest that the volcanism is slab related (Seebeck, et al., 2014). The Taranaki Basin was thought to be a back arc basin (King 1990, King \& Thrasher, 1996), however, volcanic rock mineralogy and the co-location of rifting and volcanism support the intra arc basin geological history (Bergman, et al., 1992; Stern, et al., 2006).

Volcano ages and the associated south eastward migration of the arc across the North Island have been used to infer changes in the subducting slab geometry in the last 15-20 Myr (Bergman, et al., 1992; King \& Thrasher, 1996; Giba, et al., 2010; 2013; Seebeck, et al., 2014). In a recent review of these data (including Kora volcano) Seebeck et al., (2014) proposed that arc migration over the past 20 Myr resulted from a combination of slab rollback and slab dip steepening. Seebeck et al., (2014) also highlight the parallelism of volcanic arcs with each other and suggest that unlike the overriding plate the subducting plate has not experienced clockwise vertical-axis rotation. The contrast in the rotation histories of the two plates has been interpreted to indicate that they are decoupled along the subduction thrust. The model of 
Seebeck et al. (2014) is in contrast with some previous papers (Calhaem 1973; Stern et al., 2006), which propose that vertical-axis rotation of the arc is the primary explanation for changes in the location of volcanism through time. The pole of this proposed rotation is inferred to be located west of Mount Taranaki close to the locations of vertical-axis rotation poles estimated from paleomagnetic and GPS data (Walcott, 1984; Wallace, et al., 2004).

\subsection{Discussion}

\subsection{Faults}

A number of normal faults displace the volcanic cone (Figures $5.1 \& 5.2$ ). These faults range in size (i.e. length and displacement), with the larger displacement faults generally being longer and interpreted to be tectonic in origin (refer to the chapter 4 on the faults for further discussion). In addition to these tectonic faults, a number of small displacement (e.g., $<50 \mathrm{~ms}$ ) radial faults displace the top of the cone, although these faults cannot be mapped through the volcanic cone due to attenuation of the seismic waves within volcanic rocks. These radial normal faults are inferred to be of volcanic origin (refer to the chapter 4 on the faults for further discussion).

Tectonic normal faults in the area of Kora volcano mainly formed between 6 and 12 Ma (King and Thrasher, 1996; Giba et al., 2010, 2013; Chapter 4 this thesis). Given that Kora volcanism approximately occurred between 8 and $19 \mathrm{Ma}$, there is some overlap in the timing of faulting and volcanism. It is clear however from the available dates that the onset of volcanism predates faulting by up to 9 Myr. These age relationships suggest that while Late Cenozoic faulting may have assisted the upward migration of magma in the later stages of volcanism, it was not a pre-requisite for magma reaching the seabed (Giba et al., 2013). It remains possible however, that Cretaceous normal faults, many of which were reactivated during the Late Cenozoic, could have acted as conduits for magma flow and in some cases may have influenced the location of volcanoes in the basin. Evidence for this interaction between magma flow and reactivated normal faults come in the form of the morphological shape of the Kora volcanic cone. The mapped cone is not spherical; it is $13 \mathrm{~km}$ long and $10 \mathrm{~km}$ 
wide. The strike of this cone is the same strike as the Northern Graben, and the same strike as recent and reactivated tectonic faults (King \& Thrasher, 1996; Giba, et al., 2010; 2013). Further work is required to test the hypothesis that Cretaceous faults may influence the locations of some volcanoes in the Taranaki Basin.

\subsection{Kora hydrocarbon prospectivity}

The Kora volcanic centre has been under investigation as an oil and gas prospect since the 1980's (ARCO Petroleum, 1988). Kora-1A well contained oil shows in both the Kora volcanic tuffs and the underlying Tangaroa Sandstone. Oil was flow tested from the volcanic tuffs at a sustained 668 barrels of oil per day (BOPD) (ARCO Petroleum, 1988). Oil accumulations in the Kora-1A well are contained within high porosity (e.g., up to $\sim 30 \%$ ) and permeability ( $300 \mathrm{mD}$ ) tuffs and sandstone lenses (New Zealand Petroleum and Minerals, 2014). The primary issue with the volcanic rocks as a reservoir, is that they have variable geometries laterally and vertically (OMV New Zealand Ltd, 2011). As a consequence, the reservoir geometry and quality is also variable. These variations occur on short length scales and cannot be mapped in seismic sections, which are generally of poor quality within the cone.

The Tangaroa sandstone beneath the volcanic deposits is a potential reservoir and was the first major target of drilling in the Kora and Tangaroa-1 wells. The Tangaroa sandstone has been proven to hold oil and gas with shows in the Kora-1A well. It has average porosity of $22 \%$ and permeability up to $100 \mathrm{mD}$ in the Kora-1A well (ARCO Petroleum, 1988; New Zeland Petroleum and Minerals, 2014), but the trap is hindered by a lack of seal and limited charge potential (OMV New Zealand Ltd, 2011; New Zeland Petroleum and Minerals, 2014). Faults are thought to play a major role in both seal and charge, and have been discussed in the faulting chapter (chapter 4). Mapping of the Tangaroa sandstone is difficult underneath the volcanic edifice, due to increased seismic attenuation from the volcanic rocks present.

Volcanic processes can have major effects on petroleum prospectivity. Volcanic processes bring with them thermal, hydrothermal, and deformational factors that can increase and decrease hydrocarbon prospectivity (Jørnar Heggsum, 2006; OMV 
New Zealand Ltd, 2011; Jackson, 2013; Mielke, et al., 2015). Hydrothermal fluids may decrease porosity and permeability by precipitating minerals and cementating pore space, but may also increase both porosity and permability by disolution of some grains (Mielke, et al., 2015). Heat provided by intrusion of volcanic material can theoretically bring a source rock into the oil and gas generation window, but may also push it out of the window making it 'over mature' (Jørnar Heggsum, 2006). Volcanic processes may cause folding of the overlying strata creating traps such as four-way dip closures (Jackson, 2013). This is observed in the Kora 3D where a parasistic cone to the main Kora volcanic edifice has produced a drape feature of the overlying strata. The parasistic cone is the same location as the well Kora- $1 \mathrm{~A}$ which encountered oil. Many of the effects volcanic processes can have on the prospectivity of an oil and gas rich area are unknown and in the case of the Kora 3D seismic volume remain relatively unstudied.

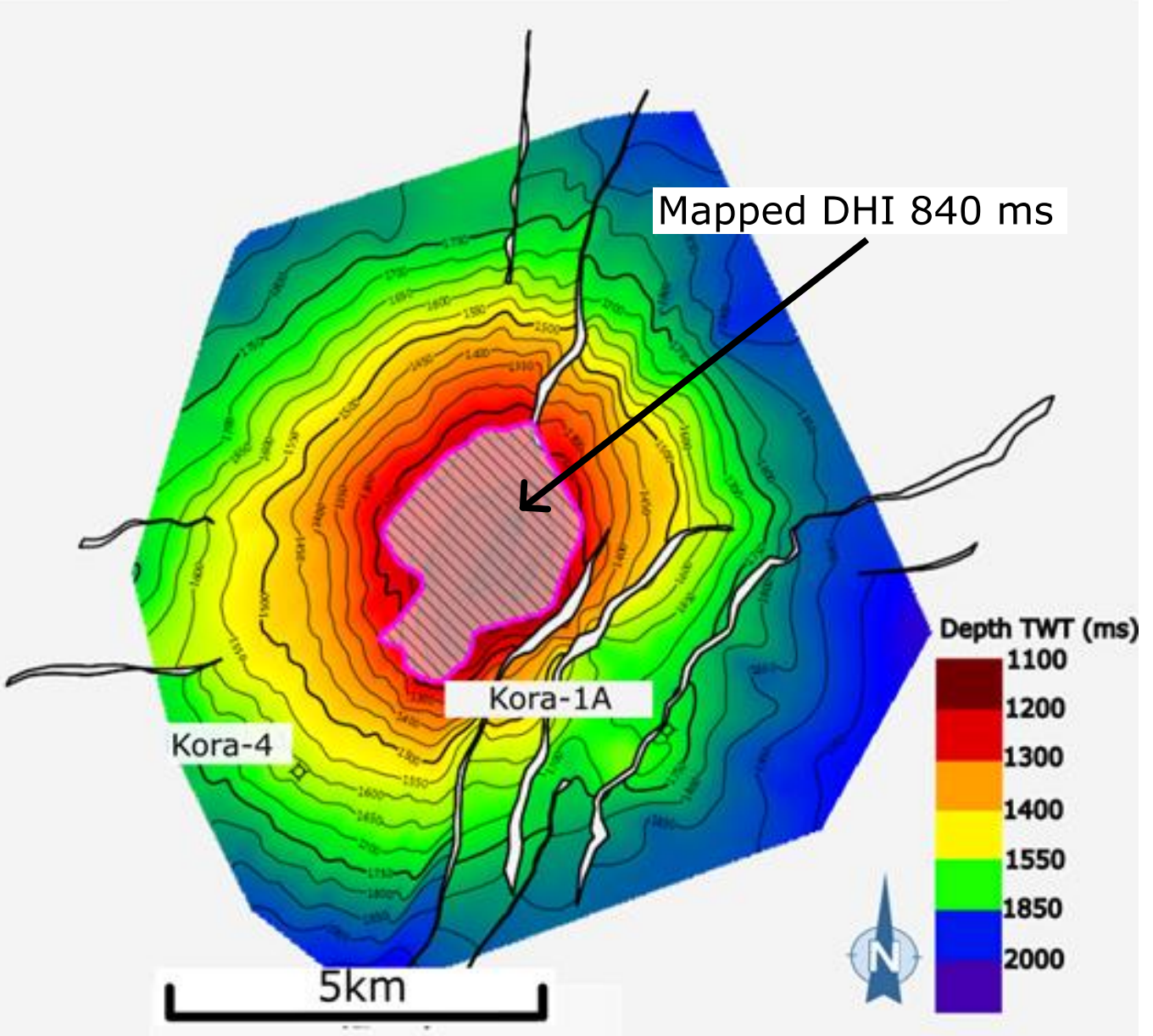

Figure 5.4. Map view of interpreted volcanic cone and intersecting faults. Also shown is mapped DHI, shown by the purple and shaded polygon. The polygon represents DHI mapped at $840 \mathrm{~ms}$. 


\subsection{Conclusions}

i. Kora Volcanic cone was active between the dates of $19 \pm 2 \mathrm{Ma}$ and $8 \pm 2 \mathrm{Ma}$. This was determined through seismic mapping of on-lapping sediments and strata underneath the cone.

ii. Kora volcanic cone was mapped in detail, shown both in map view, and imaged as a 3D model.

iii. Kora volcanic cone has not undergone erosion, implying that the cone was submerged since initiation.

iv. The Kora Volcanic cone has a typical strata cone morphology with intersecting normal faults. A parasitic cone in the location of the well Kora-1A was revealed by mapping. The parasitic cone has a height of $\sim 100 \mathrm{~ms}$.

v. Kora volcanism originated from typical intra-arc processes.

vi. The Kora volcanic reservoir is hard to map due to lateral and vertical variability. The underlying Tangaroa Sandstone is also hard to map due to seismic attenuation amplified by the volcanic rocks.

vii. Volcanic processes can have major effects on petroleum prospectivity. Volcanic processes bring with them thermal, hydrothermal, and deformational factors that can increase and decrease hydrocarbon prospectivity. Examples are given within the Kora volcanic prospects, but further study is needed on such a wide subject area. 


\section{Conclusions}

The Kora 3D and surrounding 2D lines were studied to draw conclusions on the relationship between volcanic activity and normal faulting. Mapping of faults, geological strata, and the Kora volcanic cone was carried out.

Primary outputs of this study were 7 mapped horizons throughout the Kora 3D, mapped 3D grids at multiple horizon depths, and detailed maps of fault planes from normal faults within the Kora 3D.

Faults have been classified into two categories, tectonic and radial faults. This classification is based on location of the fault to the volcanic cone and morphology of the fault trace. The initiation and death of faults within the Kora 3D has been identified and mapped. The initiation age of both radial and tectonic faults show a clear distinction. Tectonic faults show an older initiation age of $16 \mathrm{Ma}$, while radial faults have an initiation age of $12 \mathrm{Ma}$. Many of the faults mapped became inactive at $5.5 \mathrm{Ma}$, however, the larger tectonic faults have been active until recent.

The age of Kora magmatism was determined to be between $19 \pm 2 \mathrm{Ma}$ and $8 \pm 1 \mathrm{Ma}$. This was determined by mapping of stratigraphic horizons both underneath and onlapping the volcanic cone. This timing is consistent with already published data (Bergman, et al., 1992; Giba, et al., 2013).

A possible causal relationship was found between the volcanic activity and some faults within the Kora 3D survey. Volcanic activity has influenced the location and formation of radial faults within the survey. Two models were developed to show this relationship, and explain how the volcanic processes could be affecting the faulting.

The first model describes an intrusion of magmatic melt causing an uplift of overlying strata. This uplift enables stresses that form normal faults. The second model has local stress formed by volcanic material extruded during cone construction. This local stress lead to the formation of local normal faults. 
Essentially the 2 models depict two simple concepts, 1 ) a push up from below caused local faulting, and 2) weight from above caused the local faulting. The preferred model in the case of the Kora 3D survey is model 2 . When looking at the active periods of the radial faulting (12 Ma), and the active period of cone building for the Kora volcanic cone (15-8 Ma) (Bergman, et al., 1992) it is clear to see why. The radial faults were formed at the stage of extrusive cone building, as is best portrayed in model 2.

From the distribution of oil shows and amplitude anomalies I conclude that the faults within the area are open to vertical flow, but closed to lateral flow. This has an impact of the petroleum prospectivity of the Kora prospects. When the faults are sealed to lateral flow (which I conclude them to be) this significantly decreases the size of the fetch for the Kora prospects. 


\section{References}

Alessandro, T., 1995. Morphology of pyroclastic cones and tectonics. Journal of Geophysical Research, 100(12), pp. 521-524.

ARCO Petroleum, 1985. Final Well Report Kora-4. PPL 38447, Wellington: Ministry of Economic Development New Zealand Unpublished Petroleum Report PR1443. ARCO Petroleum, 1988. Final Well Report Kora-3.PPL 38447, Wellington: Ministry of Economic Development New Zealand Unpublished Petroleum Report PR1441. ARCO Petroleum, 1988. Final well report, Kora-1, Kora-1A. PPL 38447, Welington: Ministry of Economic Development New Zealand Unpublished Petroleum Report PR1374.

ARCO Petroleum, 1988. Final well report, Kora-2. PPL 38447, Wellington: Ministry of Economic Development New Zealand Unpublished Petroleum Report PR1439.

Ballance, P. F., 1975. Evolution of the upper cenozoic magmatic arc and plate boundary in northern New Zealand. Earth and Planetary Science Letters, 28(3), pp. 356-370.

Bergman, S. C., Talbot, J. P. \& Thompson, P. R., 1992. The Kora Miocene submarine andesite stratovolcano hydrocarbon reservoir, Northern Taranaki Basin, New Zealand. Wellington, Minstry of Commerce.

Booden, M. A., Smith, I. E. M., Black, P. M. \& Mauk, J. L., 2011. Geochemistry of the Early Miocene volcanic succession of Northland, New Zealand, and implications for the evolution of subduction in the Southwest Pacific. Journal of Volcanology and Geothermal Research, 199(1), pp. 25-37.

Calhaem, I. M. (1973a), Asymmetric spreading from a volcanic arc to an active continental margin, Rep. 8/73, 8 pp., Dep. of Phys., Victoria Univ. of Wellington, Wellington, New Zealand 
Campbell, M. E., Rowland, J. V., Wright, I. C. \& Smith, I. E. M., 2007. Oblique rifting along the central and southern Kermadec Arcfront $\left(30^{\circ}-36^{\circ} \mathrm{S}\right)$, SW Pacific. Geochemistry, Geophysics, Geosystems, 8(1). doi: 10.1029/2006GC001504.

Childs, C., Nicol, A., Walsh, J. J. \& Watterson, J., 2003. The growth and propagation of syn sedimentary faults. Journal of Structural Geology, 25(4), pp. 633-648.

Clayton, C., OMV NZ Ltd., 2011. 3D Basin Modelling of PEP 38485, Offshore Taranaki Basin, Wellington: Ministry of Economic Development New Zealand Unpublished Petroleum Report PR4313.

Denlinger, R. P. \& Morgan, J. K., 2014. Instability of Hawaiian Volcanoes. In: M. P. Poland, T. J. Takahashi \& C. M. Landowski, eds. Characteristics of Hawaiian Volcanoes. Washington D.C: United States Geological Survey, pp. 149-170.

Fiske, R. S. \& Jackson, E. D., 1972. Oreintation and growth of Hawaiian volcanic rifts: the effect of regional structure and gravitational forces. The Royal Society fo London, 329(1578), pp. 299-326.

Giba, M., Nicol, A. \& Walsh, J. J., 2010. Evolution of faulting and Volcanism in a Back-arc Basin and its Implications for Subduction Processes. Tectonics, 29(4). doi: 10.1029/2009TC002634.

Giba, M., Walsh, J. J. \& Nicol, A., 2012. Segmentation and growth of an obliquely reactivated normal fault. Journal of Structural Geology, Volume 39, pp. 253-267.

Giba, M. et al., 2013. Investigation of the spatio-temporal relationship between normal faulting and arc volcanism on million-year time scales. Journal of the Geological Society, 170(6), pp. 951-692.

GNS Science, 2002. Biostratigraphic reassessment of Key Western Platform Drillholes, Welington: Ministry of Economic Development New Zealand Unpublished Petroleum Report PR4525.

Hansen, J. R. \& Camp, P. J., 2004. Re-evaluation of the Late Neogene biostratigraphy of Arawa-1, Ariki-1, Kora-1, and Wainui-1 \& intergrated seismic and biostratigraphic 
correlation of 11 wells in the northern Taranaki Basin, Wellington: Ministry of Economic Development New Zealand Unpublished Petroleum Report PR2938. Hayward, Bruce W., Shell BP \& Todd Oil Services, 1986. Foraminiferal biostratigraphy and paleobathymetry of Ariki-1 offshore well, North West Taranaki PPL 38048, Wellington: Ministry of Economic Development New Zealand Unpublished Petroleum Report PR1175.

Hayward, B. W. et al., 2001. K-Ar ages of early Miocene arc-type volcanoes in northern New Zealand. New Zealand Journal of Geology and Geophysics, 44(2), pp. 285-311.

Haywood, B. W., 1985. Foraminiferal biostratigraphy of Tangaroa-1 offshore well, North West Taranaki PPL38048, Wellington: Ministry of Economic Development New Zealand Unpublished Petroleum Report PR1079.

Herzer, R. H., 1995. Seismic stratigraphy of a buried volcanic arc, Northland, New Zealand and implications for Neogene subduction. Marine and Petroleum Geology, 12(5), pp. 511-531.

Holt, W. E. \& Stern, T. A., 1994. Subduction platform subsidence, and foreland thrust loading; the late Tertiary developent of Taranaki Basin, New Zealand. Tectonics, 13(5), pp. 1068-1092.

Jackson, C. A. L., 2013. The Impact of Igneous Intrusions and Extrusions on Hydrocarbon Prospectivity in Extensional Settings:A 3D Seismic Perspective. London, AAPG Distinguished Lecture, 2012-2013 Lecture Series.

Jackson, J., 1999. Fault death: a perspective from actively deforming regions. Journal of Structural Geology, 21(8-9), p. 1003-1010.

Johnston, A. G., 2014. Interactions between the prograding gaint forsets formation and a subsiding depocentre: Insights from the Parihaka 3D and ES89 2D seismic surveys. Master's of Science Thesis, Victoria University of Wellington, New Zealand. 
Jørnar Heggsum, H., 2006. Thermal Effects of Basaltic Sill Emplacement in Source Rocks on Maturation and Hydrocarbon Generation. Doctoral Thesis, University of Oslo-Thesis Colllection, p. 275.

Killops, S. D., Woolhouse, A. D., Weston, R. J. \& Cook, R. A., 1994. A geochemical appraisal of oil generation in the Taranaki Basin, New Zealand. AAPG bulletin, 78(10), pp. 1560-1585.

King, P.R., 1990. Polyphase evolution of the Taranaki Basin, New Zealand: changes in sedimentary and structural style. In 1989 New Zealand Oil Exploration Conference Proceedings. Wellington, Ministry of Commerce (pp. 134-150).

King, P. R., 2000. Tectonic reconstructions of New Zealand: $40 \mathrm{Ma}$ to the present. New Zealand Journal of Geology and Geophysics, 43(4), pp. 611-638.

King, P. R. \& Thrasher, G. P., 1996. Cretaceous-Cenozoic geology and petroleum systems of the Taranaki Basin, New Zealand. Institute of Geological \& Nuclear Sciences monograph 13, Volume 13.

Lagmay, A.M.F., de Vries, B.V.W., Kerle, N. and Pyle, D.M., 2000. Volcano instability induced by strike-slip faulting. Bulletin of Volcanology, 62(4-5), pp.331-346.

Lamb, S., 2011. Cenozoic tectonic evolution of the New Zealand plate-boundary zone: A paleomagnetic perspective. Tectonophysics, 509(3), pp. 135-164.

Laubscher, H. P., 1987. Décollement. In: Structural Geology and Tectonics. Berlin: Springer Berlin Heidelberg, pp. 187-190.

Lerche, I., 1997. Geological risk and uncertainty in oil exploration. 1st ed. San Diego: Academic Press.

Meyer, V., Nicol, A., Childs, C. \& Walsh, J. J. W. J., 2002. Progressive localisation of strain during the evolution of a normal fault population. Journal of Structural Geology, 24(8), pp. 1215-1231.

Mielke, P., Prieto, A., Bignall, G. \& Sass, I., 2015. Effect of Hydrothermal Alteration on Rock Properties in the Tauhara Geothermal Field, New Zealand. Melbourne, World Geothermal Congress. 
Mohorovičić, A., 1910: Das Beben vom 8. X. 1909. Jahrbuch des Meteorologischen Observatoriums in Zagreb (Agram) für das Jahr 1909, 9 (4), pp. 1-63.

Moran, S. C., 1994. Seismicity at Mount St. Helens, 1987-1992: Evidence for repressurization of an active magmatic system. Journal of Geophysical Research, 99(B3), pp. 4341-4354.

Nakamura, K., 1977. Volcanoes as possible indicators of tectonic stress orientation - principle and proposal. Journal of Volcanology and Geothermal Research, 2(1), pp.1-16.

New Zealand Government, 1991. Crown Minerals Act 1991 (New Zealand). Wellington: New Zealand Government.

Nicol, A., Mazengarb, C., Chanier, F., Rait, G., Uruski, C. and Wallace, L., 2007. Tectonic evolution of the active Hikurangi subduction margin, New Zealand, since the Oligocene. Tectonics, 26(4). doi: 10.1029/2006TC002090.

Nicol, A., Walsh, J. J., Berryman, K. \& Nodder, S., 2005. Growth of a normal fault by the accumulation of slip over millions of years. Journal of Structural Geology, 27(2), pp. 327-342.

OMV New Zealand Ltd, 2011. Final Seismic interpretation report for PEP 38485 (Kora), Wellington: Ministry of Economic Development New Zealand Unpublished Petroleum Report PR4318.

Patanè, D., Gori, P. D., Chiarabba, C. \& Bonaccorso, A., 2003. Magma ascent and the pressurization of Mount Etna's volcanic system. Science, 299(5615), pp. 2061-2063.

Petroleum Engineering and Exploration Departments., Shell BP and Todd Oil Services, 1981. Well Resume - Tangaroa-1 PPL 38048 Offshore Taranaki., Wellington: Ministry of Economic Development New Zealand Unpublished Petroleum Report PR793.

PGS Geophysical, 2006. Kora 3D Seismic Survey. Offshore NZ, Wellington: Ministry of Economic Development New Zealand Unpublished Petroleum Report PR3302. 
Reilly, C., Nicol, A., Walsh, J. J. \& Seebeck, H., 2015. Evolution of faulting and plate boundary deformation in the Southern Taranaki Basin, New Zealand.

Tectonophysics, Volume 651, pp. 1-18.

Reilly, C., Nicol, A., Walsh, J. \& Kroeger, K. F., 2016. Temporal changes of fault seal and early charge of the Maui Gas-condensate field, Taranaki Basin, New Zealand. Marine and Petroleum Geology, Volume 70, pp. 237-250.

Saunders, A. \& Tarney, J., 1991. Back-arc Basins. In: P. A. Floyd, ed. Oceanic Basalts. New York: Springer, pp. 219-263.

Seebeck, H. et al., 2014. Geometry of the subducting Pacific plate since 20 Ma, Hikurangi margin, New Zealand. Journal of the Geological Society, 171(1), pp. 131143.

Shell BP and Todd Oil Services, 1984. Completion Report. Ariki-1 well. PPL 38048, Wellington: Ministry of Economic Development New Zealand Unpublished Petroleum Report PR1038.

Sigurdsson, H. et al., 2015. The Encyclopedia of Volcanoes. 2nd ed. London: Elsevier Stern, T. A. \& Davey, F. J., 1990. Deep seismic expression of a foreland basin: Taranaki Basin, New Zealand. Geology, 18(10), pp. 979-982.

Stern, T. A., Houseman, G., Salmon, M. \& Evans, L., 2013. Instability of a lithospheric step beneath western North Island, New Zealand. Geology, 41(4), pp. 423-426.

Stern, T. A., stratford, W. R. \& Salmon, M. L., 2006. Subduction evolution and mantle dynamics at a continental margin: Central North Island, New Zealand. Reveiws of Geophysics, 44(4). doi:10.1029/2005RG000171.

Strogen, D. P. \& King, P. R., 2014. A New Zealandia-Wide Seismic Horizon Naming Scheme, Lower Hutt, New Zealand: Institute of Geological and Nuclear Sciences. Strong, C., 2006. Foraminiferal Biostratigraphy of the Tangaroa Sandstone, Offshore North Taranaki, Wellington: Ministry of Economic Development New Zealand Unpublished Petroleum Report PR3645. 
Strong, D. B. \& Crampton, J. S., 1996. Biostratigraphic review of the Late Miocene and Pliocene of the Mangaa-1, Kahawai-1, Te Kumi-1, Tangaroa-1 and Kora-1 wells, offshore Taranaki Basin. PEP38457, Wellington: Ministry of Economic Development New Zealand Unpublished Petroleum Report PR2417.

Tiab, D. \& Donaldson, E. C., 2004. Petrophysics. 2nd ed. Oxford: Elsevier.

Townsend, D., Vonk, A. \& Kamp, P. J. J., 2008. Geology of the Taranaki Area 1:250000 geological map, Lower Hutt, New Zealand: Institute of Geological and Nuclear Sciences.

Twiss, R. J. \& Moores, E. M., 2007. Structural Geology. 2nd ed. New York: Freeman. USGS, 2011. Principal Types of Volcanoes. [Online] Available at: https://pubs.usgs.gov/gip/volc/types.html Uyeda, S., 1982. Subduction zones: an introduction to comparative subductology. Tectonophysics, 81(3-4), pp. 133-159.

Waghorn, D. B., Strong, P. C., Raine, I. J. \& Crampton, J. S., 1996. Biostratigraphic review of the Late Miocene and Pliocene of the Mangaa-1, Kahawai-1, Te Kumi-1, Tangaroa-1 and Kora-1 wells, offshore Taranaki Basin. PEP38457, Wellington: Ministry of Economic Development New Zealand Unpublished Petroleum Report PR2417.

Walcott, R. I., 1984. The kinematics of the plate boundary zone through New Zealand: a comparison of short-and long-term deformations. Geophysical Journal of the Royal Astronomical Society, 79(2), pp. 613-633.

Wallace, L. M., Beavan, J., R, M. \& Darby, D., 2004. Subduction zone coupling and tectonic block rotations in the North Island, New Zealand. Journal of Geophysical Research: Solid Earth, 109(B12). doi: 10.1029/2004JB003241.

Walsh, J. J. et al., 2001. Geometric controls on the evolution of normal fault systems. Geological Society, London, Special Publications, 186(1), pp. 157-170. 
Young Technology, 2016. Online Rose Diagram. [Online]

Available at: http://www.yongtechnology.com/yong-lab/online-rose-diagram/

[Accessed 51 2016]. 


\section{Appendices}

\section{Appendix A- Kora 3D Acquisition Parameters}

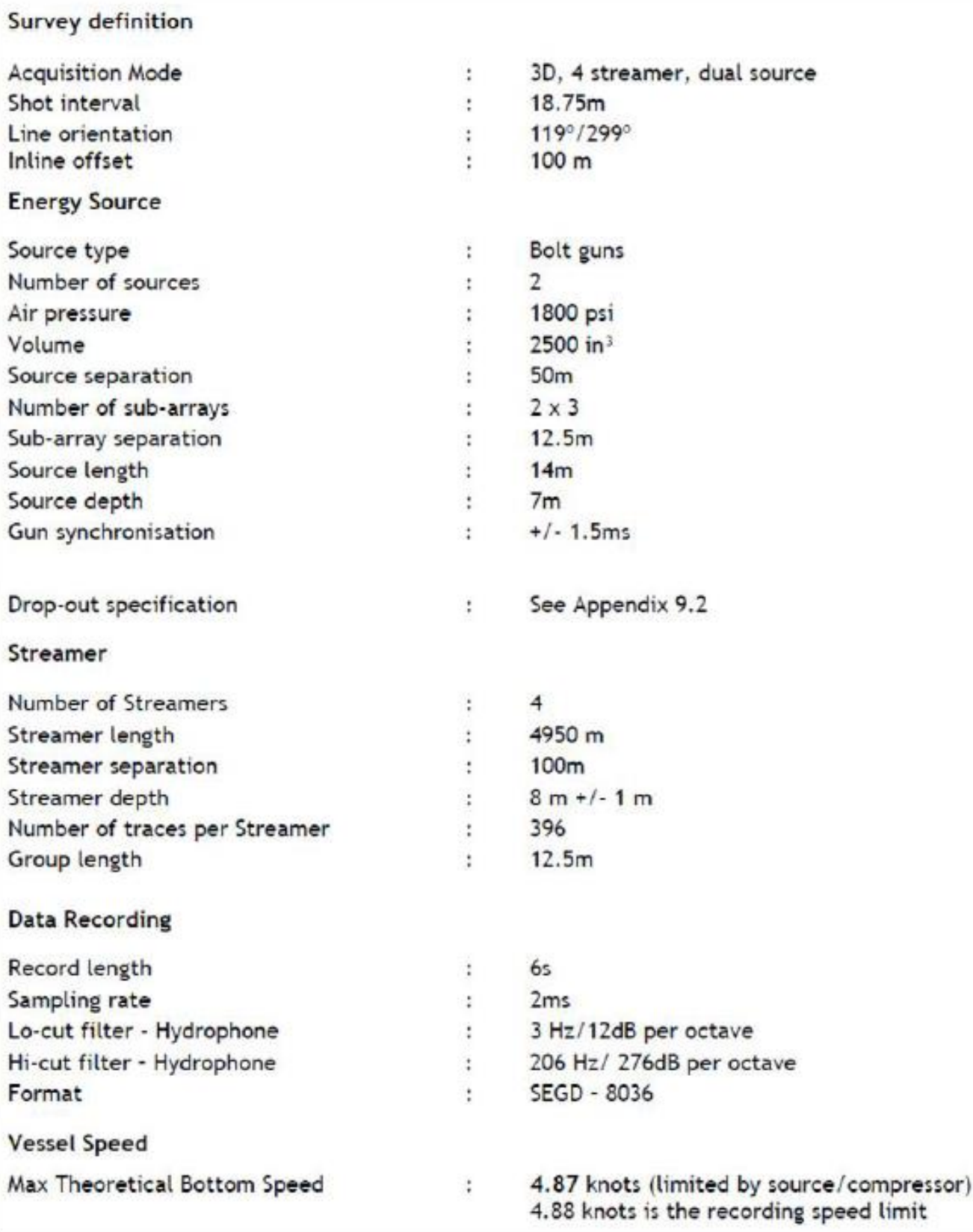

Appendix A1. Kora 3D acquisition parameters. Taken from OMV New Zealand Ltd., 2011 PR report 4318 


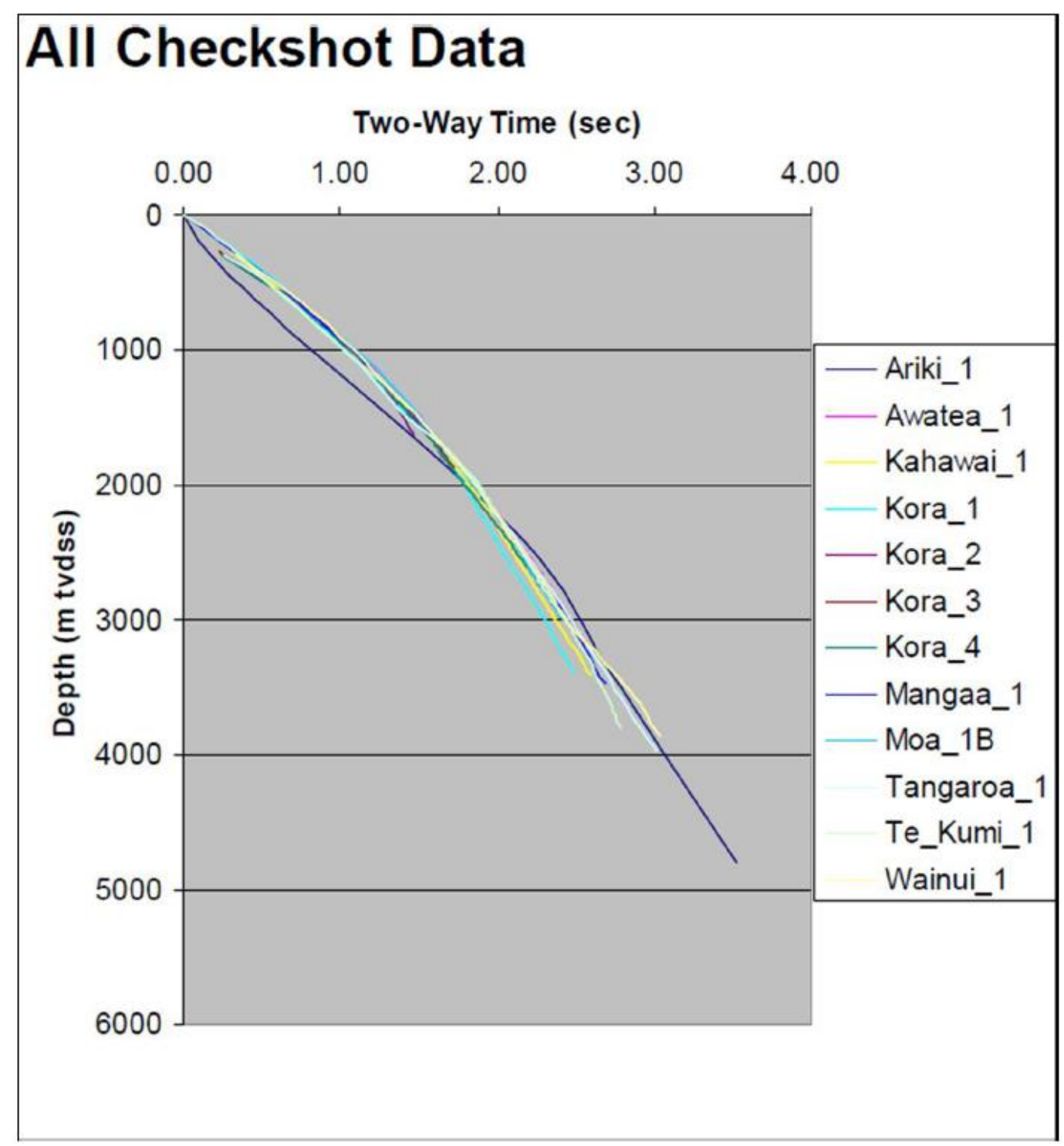

Appendix B1. Time Depth Curves for used and nearby wells. Taken from OMV New Zealand Ltd., 2011 PR report 4318 


\section{Appendix C- Well Data Table}

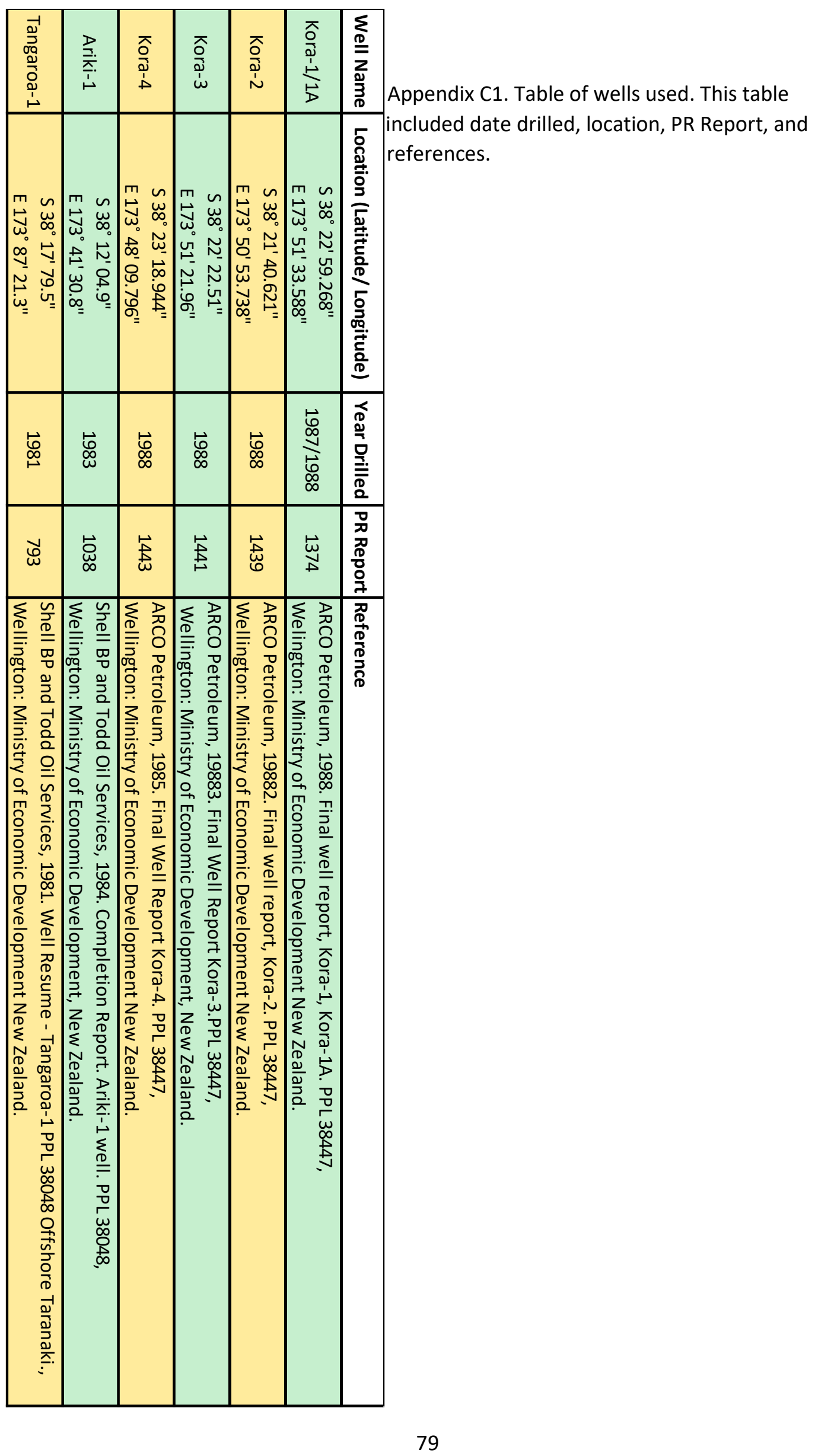




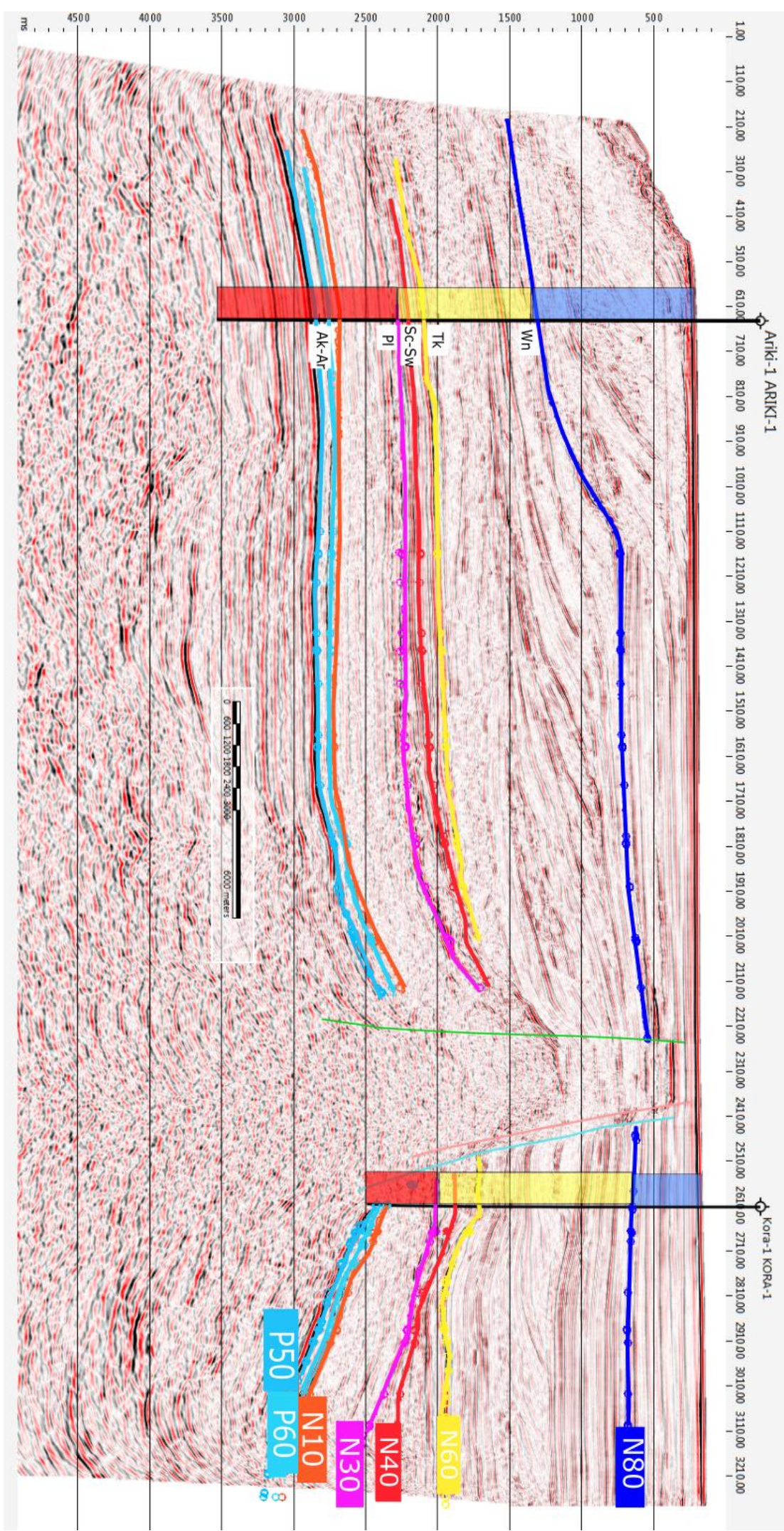

Appendix D1. Well tie between Kora-1 and Ariki-1. Mapped horizons on the well tie are $\mathrm{N} 80, \mathrm{~N} 60, \mathrm{~N} 40, \mathrm{~N} 30, \mathrm{~N} 10, \mathrm{P} 60$, and P50. Also marked on the wells are correlated sediment packages. 


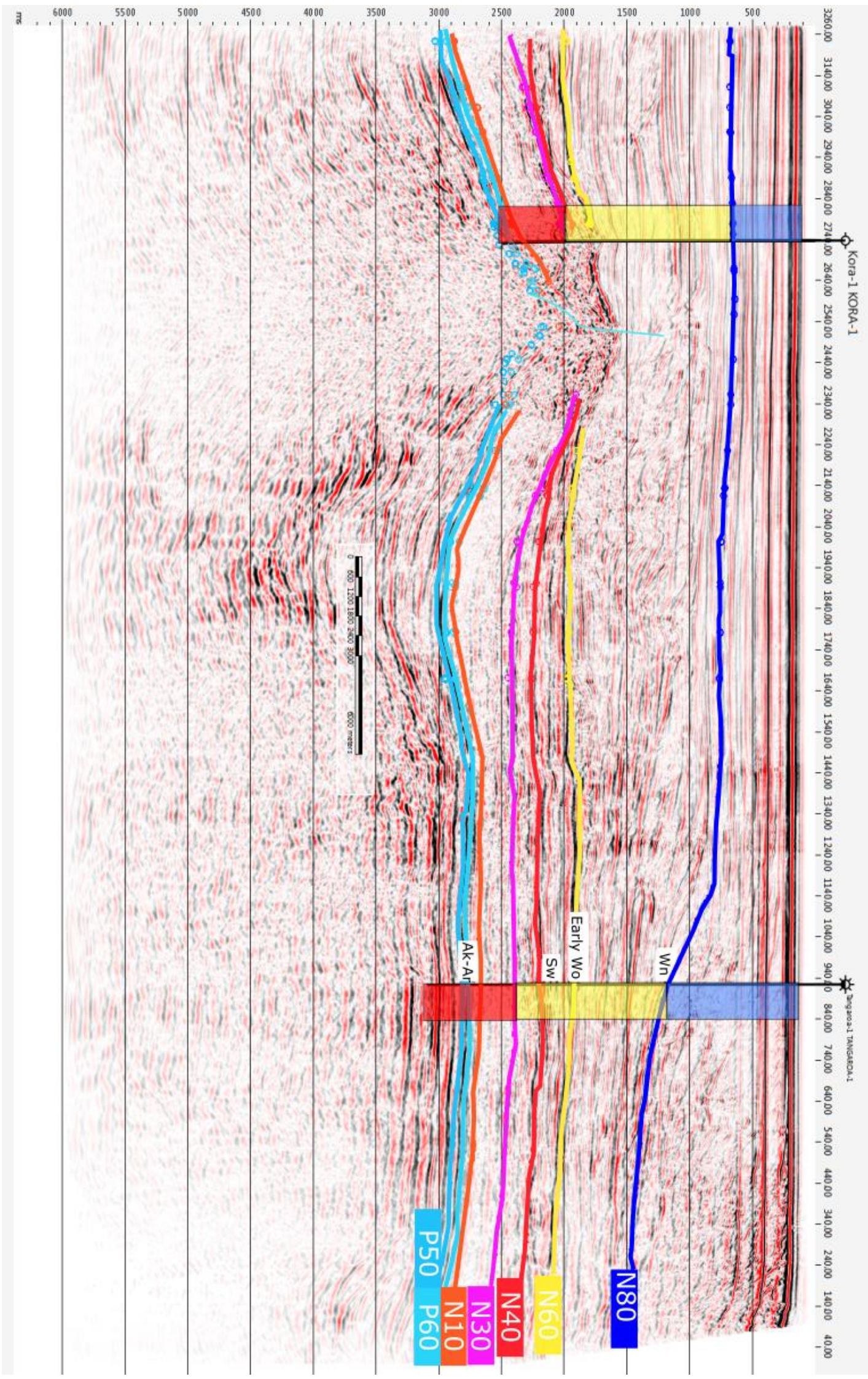

Appendix D1. Well tie between Kora-1 and Tangaroa-1. Mapped horizons on the well tie are $\mathrm{N} 80, \mathrm{~N} 60, \mathrm{~N} 40, \mathrm{~N} 30, \mathrm{~N} 10, \mathrm{P} 60$, and P50. Also marked on the wells are correlated sediment packages. 


\section{Appendix E-Created Horizon Grids}

\section{Appendix E1.N10 Grid}
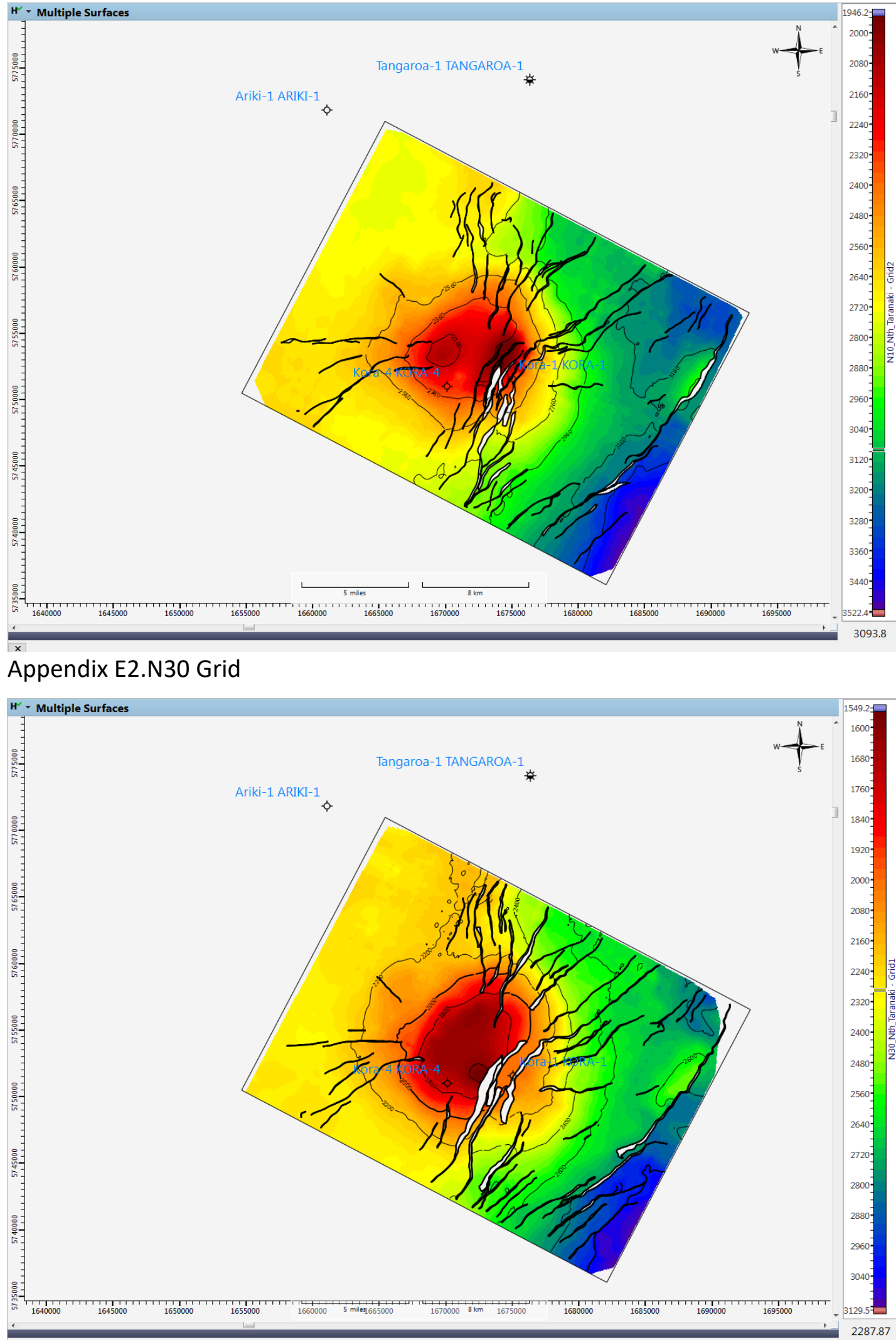


\section{Appendix E3.N40 Grid}

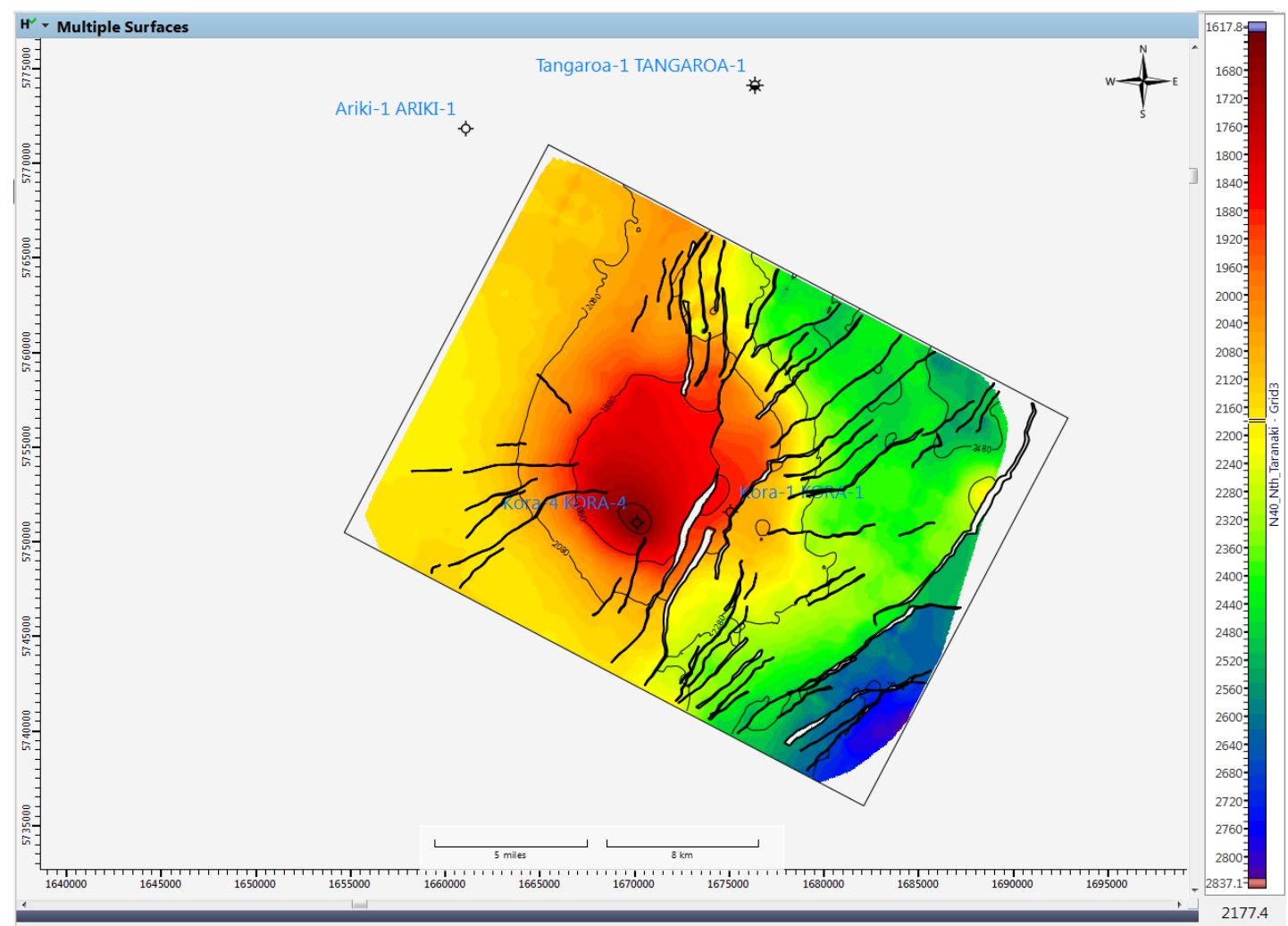

\section{Appendix E4.N60 Grid}

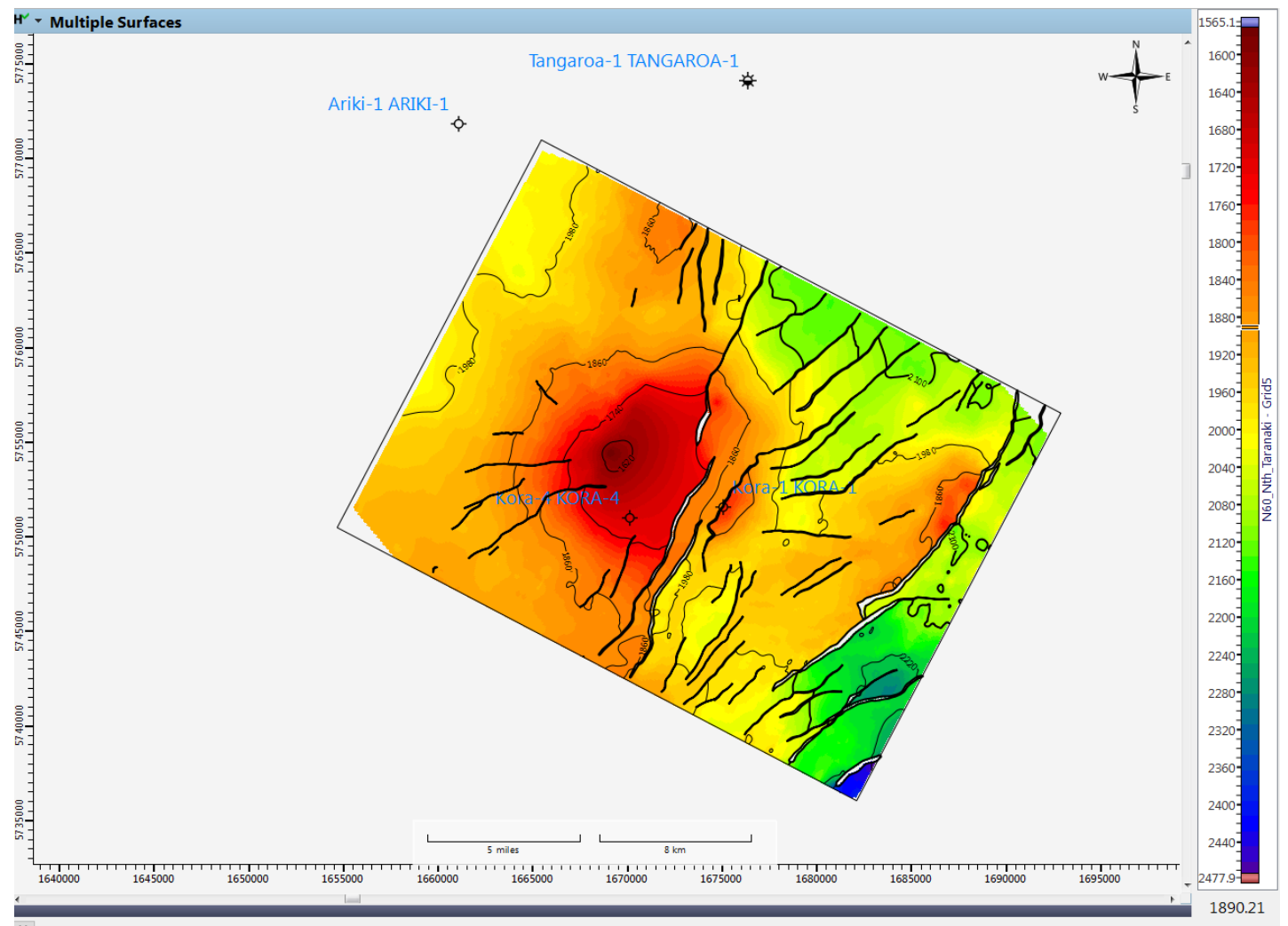




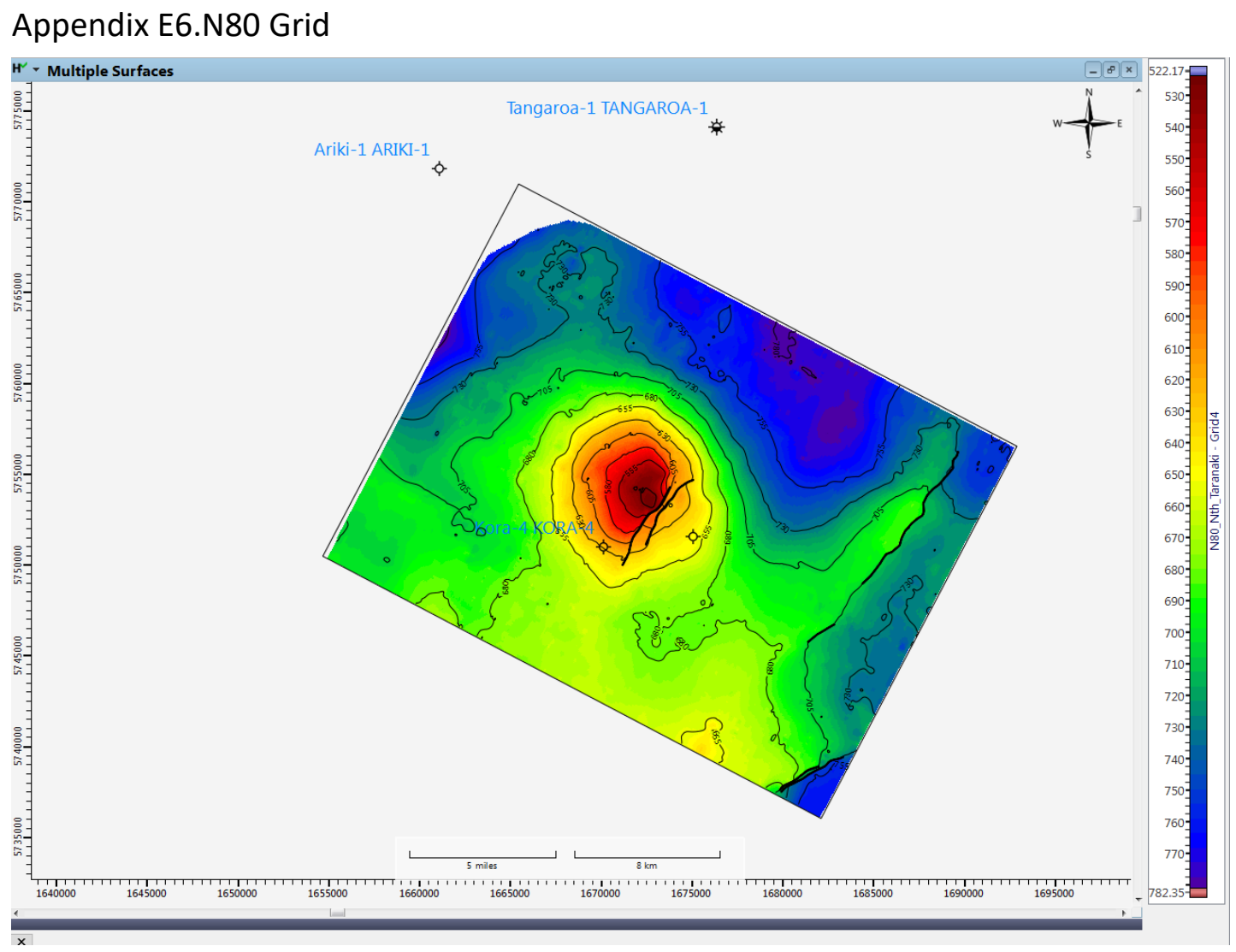




\begin{tabular}{|c|c|c|c|}
\hline Category & Survey & Line & Year acquired \\
\hline \multirow{12}{*}{ 2D lines } & 81sy & $12-2174$ & 1981 \\
\hline & \multirow{9}{*}{$\operatorname{ar} 88$} & 447-117 & \multirow{9}{*}{1988} \\
\hline & & $447-118$ & \\
\hline & & 447-119 & \\
\hline & & $447-120$ & \\
\hline & & $447-122$ & \\
\hline & & $447-123$ & \\
\hline & & $447-125$ & \\
\hline & & $447-127$ & \\
\hline & & $447-129$ & \\
\hline & \multirow{2}{*}{ dtb01 } & $03-2847$ & \multirow{2}{*}{2001} \\
\hline & & $36-2847$ & \\
\hline \multirow{2}{*}{ 3D surveys } & \multirow{2}{*}{ Kora } & Pre-stack migration & \multirow{2}{*}{$2005 / 2006$} \\
\hline & & Coherance & \\
\hline
\end{tabular}

Appendix F1. Table seismic lines and surveys used in this study. Also found on the table are the dates of the year acquired and survey categories. 